$$
\begin{gathered}
\text { UNIVERSIDADE DE SÃO PAULO } \\
\text { INSTITUTO DE ENERGIA E AMBIENTE } \\
\text { PROGRAMA DE PÓS-GRADUAÇÃO EM ENERGIA }
\end{gathered}
$$

RODRIGO BRANDÃO FONTOURA

\title{
PROGRAMA DE INTEGRIDADE: UMA AVALIAÇÃO PARA AS DISTRIBUIDORAS DE ENERGIA ELÉTRICA NO BRASIL
}

SÃO PAULO 


\title{
PROGRAMA DE INTEGRIDADE: UMA AVALIAÇÃO PARA AS \\ DISTRIBUIDORAS DE ENERGIA ELÉTRICA NO BRASIL
}

\author{
Dissertação apresentada ao \\ Programa de Pós-Graduação em \\ Energia do Instituto de Energia e \\ Ambiente da Universidade de São \\ Paulo para obtenção do título de \\ Mestre em Ciências. \\ Orientadora: Prof ${ }^{a}$ Dr $^{a}$ Virginia Parente
}

\section{SÃO PAULO}


AUTORIZO A REPRODUÇÃO E DIVULGAÇÃO TOTAL OU PARCIAL DESTE

TRABALHO, POR QUALQUER MEIO CONVENCIONAL OU ELETRÔNICO,

PARA FINS DE ESTUDO E PESQUISA, DESDE QUE CITADA A FONTE.

FICHA

CATALOGRÁFICA

Fontoura, Rodrigo Brandão.

Programa de integridade: uma avaliação para as distribuidoras de energia elétrica no Brasil. Rodrigo Brandão Fontoura;

orientadora: Virginia Parente. - São Paulo, 2019.

$148 \mathrm{f.:} \mathrm{il;} 30 \mathrm{~cm}$

Dissertação (Mestrado em Ciências) - Programa de Pós-Graduação em Energia - Instituto de Energia e Ambiente da Universidade de São Paulo.

1. Energia elétrica - distribuição - Brasil. 2. Corrupção. I. Título.

Elaborado por Maria Penha da Silva Oliveira CRB-8/6961 


\section{UNIVERSIDADE DE SÃO PAULO \\ INSTITUTO DE ENERGIA E AMBIENTE \\ PROGRAMA DE PÓS-GRADUAÇÃO EM ENERGIA}

\section{RODRIGO BRANDÃO FONTOURA}

Programa de Integridade: uma avaliação para as distribuidoras de energia elétrica no Brasil.

Dissertação defendida em aprovada em 10/10/2019 pela Comissão Julgadora:

Profa. Dra. Virginia Parente - PPGE/USP

Prof. Dr. José Roberto Kassai - FEA/USP

Prof. Dr. Fernando M. R. Marques - Fundação Instituto de Pesquisa

Profa. Dra. Lucy Sousa - PECE-POLI/USP 


\section{AGRADECIMENTOS}

À caríssima Prof ${ }^{\mathrm{a}} \mathrm{Dr}^{\mathrm{a}}$ Virginia Parente, pelos valorosos ensinamentos que proveu a mim durante o todo o curso de mestrado, principalmente no período que dedicou à minha orientação.

Aos professores, funcionários e colegas do IEE, que contribuíram para que eu pudesse trilhar, nesta academia, o glorioso caminho do conhecimento, especialmente à Juliana Oliveira da Silva, Chefe Administrativa do serviço de Pós-Graduação.

Ao amigo, Dr. Sidney Simonaggio, profissional que tenho em mais alta estima e que foi responsável por me apontar o caminho junto ao IEE.

Aos meus amigos e colegas de trabalho, que contribuíram com seus conhecimentos para realização desta importante etapa da minha carreira acadêmica.

À minha esposa Ana Claudia e aos meus filhos Marcus Vinicius e Mariah Fernanda, que pacientemente me ajudaram a transpor esse difícil, mas revigorante período da minha vida, dando apoio incondicional nos momentos mais necessários. 


\section{RESUMO}

FONTOURA, Rodrigo Brandão. Programa de Integridade: uma avaliação para as distribuidoras de energia elétrica no Brasil. 2019. 148 p. Dissertação (Mestrado). Programa de Pós-Graduação em Energia. Universidade de São Paulo. São Paulo. 2019.

Os inúmeros casos de corrupção revelados pela Polícia Federal brasileira a partir de 2005 e a consequente posição que o Brasil ocupa no ranking de percepção da corrupção, divulgado anualmente pela Transparência Internacional, expuseram um cenário de corrupção endêmica no país. A percepção pública dessa corrupção, por sua vez, trouxe uma crise de credibilidade nas instituições brasileiras, diminuindo o interesse de investidores estrangeiros e prejudicando a economia nacional de forma generalizada. Com a regulamentação da Lei Anticorrupção Brasileira em 2015 surgiu a possibilidade de as empresas brasileiras, com destaque para as distribuidoras de energia elétrica, mitigarem os efeitos dessa falta de credibilidade, através do instituto jurídico denominado Programa de Integridade. Assim, é nesse contexto que se insere a presente dissertação, cujo objetivo foi o de avaliar a qualidade dos Programas de Integridade implementados por duas das maiores distribuidoras de energia elétrica do país. Para tanto, foi realizada uma pesquisa nas distribuidoras selecionadas, de forma a analisar o nível de conformidade dos seus Programas de Integridade, considerando as características, metodologias e lacunas dos referidos Programas. A análise indicou que, embora haja conformidade em relação à maioria dos aspectos exigidos pela legislação que rege tais Programas, foram identificadas lacunas e pontos de não-conformidade que podem ser corrigidos para seu aprimoramento. Mais especificamente, dentre as principais não-conformidades identificadas, destacam-se aquelas que dizem respeito à seara regulatória, cujo descumprimento pode dar origem a não-conformidades de integridade e consequente imputação de penalidades a essas empresas.

Palavras-chave: PROGRAMA DE INTEGRIDADE; DISTRIBUIDORAS DE ENERGIA ELÉTRICA; CONFORMIDADE; COMPLIANCE; LEI ANTICORRUPÇÃO BRASILEIRA. 


\begin{abstract}
FONTOURA, Rodrigo Brandão. Integrity Program: an evaluation for electric power distributors in Brazil. 2019. 148 pages. Dissertation (Master's). Graduate Program in Energy. University of Sao Paulo. Sao Paulo. 2019.

The numerous cases of corruption revealed by the Brazilian Federal Police since 2005 and the consequent position that Brazil occupies in the corruption perception ranking, published annually by Transparency International, revealed a scenario of endemic corruption in the country. The public perception of this corruption, in turn, brought a crisis of credibility in Brazilian institutions, diminishing the interest of foreign investors and damaging the national economy in a general way. With the regulation of the Brazilian Anti-Corruption Law in 2015, it became possible for Brazilian companies, especially electricity distributors, to mitigate the effects of this lack of credibility through the legal institute called the Integrity Program. Thus, it is in this context that this dissertation fits in, whose objective was to evaluate the quality of the Integrity Programs implemented by two of the largest electricity distributors in the country. To this end, a survey was conducted in the selected distributors, in order to analyze the level of compliance of their Integrity Programs, considering the characteristics, methodologies and gaps of these Programs. The analysis indicated that while there is compliance with most aspects required by the legislation governing such Programs, gaps and non-compliance points that can be corrected for improvement have been identified. More specifically, among the main nonconformities identified, we highlight those related to the regulatory area, whose noncompliance may lead to nonconformities of integrity and consequent imputation of penalties to these companies.
\end{abstract}

Key words: ITEGRITY PROGRAM, DISTRIBUTORS AND ELECTRICITY, CONFORMITY STANDARTS; COMPLIANCE; ANTI-CORRUPTION LAW. 


\section{SUMÁRIO}

CAPÍTULO 1. INTRODUÇÃO

1.1. Motivação, Justificativa e Relevância do Tema 01

1.2. Objetivos, Questão Central e Hipótese 05

1.3. Metodologia 06

CAPÍTULO 2. RESUMO HISTÓRICO DA CORRUPÇÃO E SEUS RESPECTIVOS EFEITOS 09

2.1. Conceito e Classificação da Corrupção 09

2.2. Resumo Histórico da Corrupção no Brasil e no Mundo 14

2.3. A Operação Lava Jato e seus desdobramentos 21

2.4. Índice de Percepção da Corrupção 25

2.5. Efeitos da Corrupção sobre a Credibilidade 30

CAPÍTULO 3. LEGISLAÇÃO ANTICORRUPÇÃO 33

3.1. Legislação Anticorrupção Internacional 33

3.2. Legislação Anticorrupção Brasileira 45

CAPÍTULO 4. COMPLIANCE DE INTEGRIDADE 61

4.1. Conceito e Classificação de Compliance 61

4.2. Programa de Integridade 65

4.3. Certificação do Programa de Integridade 73

CAPÍTULO 5. DISTRIBUIDORAS DE ENERGIA ELÉTRICA E SEU PROTAGONISMO NO CENÁRIO DE INTEGRIDADE 77

5.1. Breve Panorama sobre as Distribuidoras de Energia Elétrica no Brasil $\quad 77$

5.2. Protagonismo das Distribuidoras em Questões de Integridade 83

CAPÍTULO 6. ANÁLISE DOS PROGRAMAS DE INTEGRIDADE NAS EMPRESAS DISTRIBUIDORAS DE ENERGIA ELÉTRICA

6.1. Metodologia de Avaliação e Premissas Utilizadas 
6.2. Análise do Programa de Integridade das Distribuidoras Pesquisadas

7.1. Análise dos Resultados Obtidos 111

7.2. Conclusões 115

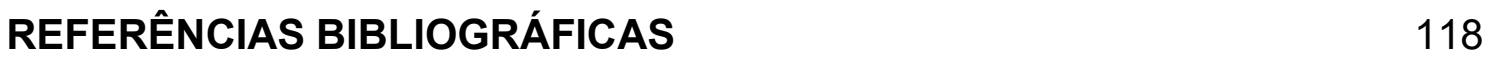

$\begin{array}{ll}\text { ANEXOS } & 133\end{array}$

Anexo 1 - Questionário de Avaliação Empresa Pró-Ética Elaborado Pela Controladoria Geral da União

Anexo 2 - Questionário Padrão sobre o Programa de Integridade Enviado para as Distribuidoras de Energia Elétrica Pesquisadas

Anexo 3 - Questionário sobre o Programa de Integridade respondido pela Primeira Distribuidora Avaliada

Anexo 4 - Questionário sobre o Programa de Integridade respondido pela Segunda Distribuidora Avaliada 


\section{LISTA DE FIGURAS E TABELAS}

\section{FIGURAS}

Figura 1 - Quadro de Heidenheimmer.

Figura 2 - Estatísticas da Operação Lava Jato.

Figura 3 - Perception Corruption Index.

Figura 4 - Pontuação Brasil no Índice de Percepção da Corrupção.

Figura 5 - Pontuação dos BRICS no Índice de Percepção da Corrupção.

Figura 6 - Histórico das Notas Referentes ao Grau de Investimento Brasil entre 2003 e 2018 das Agências S\&P, Fitch e Moody's.

Figura 7 - Quadro Comparativo - Alcance Legal das Entidades Jurídicas Envolvidas em Práticas Anticorrupção.

Figura 8 - Régua do Compliance.

Figura 9 - 5 Pilares do Programa de Integridade.

Figura 10 - Passo a Passo - Selo Empresa Pró-Ética.

Figura 11 - Questionário de Avaliação - Selo Empresa Pró-Ética.

Figura 12 - Relação das Empresas Pró-Ética.

Figura 13 - Quadro dos Resultados Obtidos

\section{TABELAS}

Tabela 1 - Brasil - Empresas Concessionárias de Distribuição de Energia Elétrica (ABRADEE). 


\section{LISTA DE SIGLAS E ABREVIATURAS}

ABRADEE Associação Brasileira de Distribuidores de Energia Elétrica

ACR

Ambiente de Contratação Regulada

$A C L$

Ambiente de Contratação Livre

ANEEL

Agência Nacional de Energia Elétrica

BOVESPA

Bolsa de Valores Mobiliários do Estado de São Paulo

CCJ

Comissão de Constituição e Justiça

CEIS

Cadastro de Empresas Inidôneas e Suspensas

CEO

Chief Executive Officer

CEPIM

Cadastro de Entidades Privadas Sem Fins Lucrativos Impedidas

CGM

Controladoria Geral do Município de São Paulo

CGU

Controladoria Geral da União

CNEP

Cadastro Nacional de Empresas Punidas

coso

Committee of Sponsoring Organizations of the Treadway Commission

CVM

Comissão de Valores Mobiliários

DEC

Duração Equivalente de Interrupção por Unidade Consumidora

DIC Duração de Interrupção Individual por Unidade Consumidora

DMIC Duração Máxima de Interrupção Contínua por Unidade Consumidora ou Ponto de Conexão

DOJ Department of Justice

$D P A$

Deferred Prosecution Agreement

EPE

Empresa de Pesquisa Energética

EUA

Estados Unidos da América

$\mathrm{FBI}$

Federal Bureau of Investigation

FCPA

Foreing Corrupt Practices Act

FEC

Frequência Equivalente de Interrupção por Unidade Consumidora

FIC Frequência de interrupção individual por unidade consumidora

GW

Giga Watt 


$\begin{array}{ll}\text { GWh } & \text { Giga Watt Hora } \\ \text { ILG } & \text { Índice de Liquidez Geral } \\ \text { ISG } & \text { Índice de Solvência Geral } \\ \text { kW } & \text { Kilo Watt } \\ \text { kWh } & \text { Kilo Watt Hora } \\ \text { LAB } & \text { Lei Anticorrupção Brasileira } \\ \text { LE } & \text { Lei das Estatais } \\ \text { MPF } & \text { Ministério Público Federal } \\ \text { MW } & \text { Mega Watt } \\ \text { MWh } & \text { Mega Watt Hora } \\ \text { NPA } & \text { Non-Prosecution Agreement } \\ \text { OCDE } & \text { Organização para a Cooperação e Desenvolvimento } \\ & \text { Econômico } \\ \text { OEA } & \text { Organização dos Estados Americanos } \\ \text { ONU } & \text { Organização das Nações Unidas } \\ \text { PAR } & \text { Processo Administrativo de Responsabilização } \\ \text { PBP } & \text { Plea Bargaining Processs } \\ \text { PEP } & \text { Pessoa Exposta Politicamente } \\ \text { PIB } & \text { Produto Interno Bruto } \\ \text { PLS } & \text { Projeto de Lei do Senado } \\ \text { PRODIST } & \text { Procedimentos de Distribuição } \\ \text { RTA } & \text { Reajuste Tarifário Anual } \\ \text { RTP } & \text { Revisão Tarifária Periódica } \\ \text { SAFI } & \text { Sociedad Anónima Financiera de Inversión } \\ \text { SEB } & \text { Setor Elétrico Brasileiro } \\ \text { SFO } & \text { Serious Fraud Office } \\ \text { STF } & \text { United Kingdom Bribery Act } \\ \text { UKBA } & \\ & \end{array}$




\section{CAPÍTULO 1. INTRODUÇÃO}

\subsection{Motivação, Justificativa e Relevância do Tema}

O Brasil ocupava a $105^{a}$ posição no ranking de percepção de corrupção no setor público (Corruption Perception Index), divulgado no ano de 2019 pela organização não-governamental conhecida como Transparência Internacional. No referido ranking, do qual constava 180 nações, o país está em uma posição precária que indica uma alta percepção da corrupção, estando atrás de países como Cuba, Grécia, Ruanda e Botsuana.

Neste sentido, deve ser ressaltado que ficar atrás de países historicamente conhecidos pela elevada corrupção, como algumas nações africanas, que estão notadamente entre as mais problemáticas, não é uma boa sinalização. Quadro pior é configurado quando se verifica que o Brasil, se comparado a outros países pertencentes a segmentos econômicos estratégicos, também não estaria numa boa posição.

Assim, se focarmos nos países que compõem à América Latina, por exemplo, verificamos que o Brasil está atrás de Uruguai, Argentina e Chile. Já se a amostra disser respeito aos $B R I C S^{1}$, fica ainda mais evidente a posição de precariedade brasileira, uma vez que o Brasil está somente à frente da Rússia no quesito percepção da corrupção (TRANSPARÊNCIA INTERNACIONAL, 2019).

De todo modo, este é um cenário bastante preocupante quando visto em qualquer um de seus aspectos. Pela perspectiva do lado social, há uma quantidade expressiva de pessoas que têm suas vidas prejudicadas pela corrupção. Essas pessoas são afetadas através do dinheiro que deixa de ser aplicado no atendimento a necessidades sociais prioritárias, como saúde, educação, segurança e bem-estar social. Deste modo, os recursos públicos são desviados da coletividade para os indivíduos que se beneficiam com a

\footnotetext{
${ }^{1}$ Que são os países pertencentes ao bloco de economia emergente, em destaque no cenário globalizado, composto por Brasil, Rússia, Índia, China e África do Sul/ South Africa.
} 
corrupção, causando estragos contundentes na sociedade e na segurança das instituições (BANCO MUNDIAL, 2019).

Sob o ponto de vista econômico, investimentos deixam de ser trazidos ao país, em virtude da alta probabilidade de envolvimento em corrupção. Ademais, isso onera o custo de abertura de empresas nos países que possuem altos índices de corrupção, além de ampliar o tempo de retorno dos investimentos neles realizados (DAMODARAN, 2019).

Vale ressaltar que atuar em um país com elevado índice de corrupção implica em suportar os custos referentes aos investimentos direcionados à implementação de programas de prevenção à corrupção e à contratação de funcionários e prestadores especializados no tema. Assim, torna-se um grande risco investir em países corruptos, não só pela potencial desvalorização da moeda, mas também pelo risco político decorrente da sequência de ações de corrupção que se atrelam à corrupção original (MONTEIRO; 2016).

Como exemplo, é possível observar que no caso brasileiro passam também a ser considerados como gastos inerentes ao investimento todos os custos relacionados à implementação de controles internos e compliance ${ }^{2}$. Além disso, surge a necessidade de se estruturar áreas ligadas ao controle de riscos, auditoria e monitoramento, o que onera bastante o custo do investimento, notadamente em startups e joint ventures ligadas a empresas multinacionais (BANCO MUNDIAL, 2018).

De todo modo, visto por qualquer um de seus aspectos, e dada a dimensão que alcançou no Brasil, a corrução, nesta segunda década do século, tomou proporções endêmicas, de acordo com Rezende (2019). Metaforicamente, para este autor, pode-se partir da premissa de que a corrupção é uma doença que se

\footnotetext{
2 Por Compliance entende-se agir de acordo com a lei, uma instrução interna, um comando ou uma conduta ética, ou seja, estar em compliance é estar em conformidade com as regras internas da empresa, de acordo com procedimentos éticos e as normas jurídicas vigentes. Tal conceito será mais bem detalhado no Capítulo 4.
} 
espalha pelo organismo social do país, cuja incidência é constante e local, ou seja, dentro de suas fronteiras.

A percepção dessa corrupção, por sua vez, trouxe uma crise de credibilidade sem precedentes, diminuindo o interesse de investidores estrangeiros no país, prejudicando a economia de forma generalizada. Saliente-se que esse quadro tem sido reforçado diariamente pelas notícias de corrupção divulgadas ao mundo, sobre o Brasil, gerando uma exposição internacional negativa, e agravando o quadro acima exposto.

Agências de rating internacional, como a Standard and Poor's, Moddy's, e Fitch, rebaixaram a nota de crédito do Brasil. O país passou a ser considerado de alto risco para a realização de investimentos, tanto em função da corrupção existente e seus riscos para o negócio, quanto pela consequência econômica e de investimento dessa corrupção,

Note-se que não é coincidência que as notas do Brasil tenham sido rebaixadas, pelas principais agências, exatamente no período em foi deflagrada a Operação Lava Jato ${ }^{3}$. A referida operação teve seu início no ano de 2014 , e foi amplamente divulgada à mídia. Ela é considerada a principal operação policial de combate à corrupção no Brasil, e neste ano de 2019 já conta com mais de 61 fases (MPF; 2019). Ademais, a Operação Lava Jato trouxe à tona o caso de corrupção que é considerado o segundo maior já registrado no mundo, após o caso revelado pela Operação Mãos Limpas na Itália (ESTADO DE SÃO PAULO, 2019).

Todavia, com o advento da Lei Anticorrupção Brasileira (LAB) ${ }^{4}$, em 2013, e, posteriormente, em 2015, com a promulgação do decreto que a regulamentou ${ }^{5}$, a responsabilidade pela prática de atos de corrupção deixou de ser exclusividade das pessoas físicas e passou também a ser atribuída às pessoas jurídicas. Além disso, a referida legislação adotou o sistema de responsabilidade objetiva,

\footnotetext{
${ }^{3}$ A Operação Lava Jato é um conjunto de investigações em andamento pela Polícia Federal do Brasil, que investiga crimes de corrupção ativa e passiva, gestão fraudulenta, lavagem de dinheiro, organização criminosa, obstrução da justiça, operação fraudulenta de câmbio e recebimento de vantagem indevida.

${ }^{4}$ Lei no 12.846 , de 1 o de agosto de 2013.

${ }^{5}$ Decreto n.o 8.420 de 18 de março de 2015.
} 
imputando a penalização dessas pessoas sem a necessidade de comprovação de culpa, através da esfera administrativa e judicial.

Neste diapasão, para tentar prevenir os efeitos negativos da corrupção, seja em função dos malefícios econômicos trazidos pela perda da credibilidade do país, ou simplesmente pela possibilidade de imputação direta das penalizações decorrentes da lei, diversas empresas no Brasil passaram a ser preocupar, desde o advento da Lei Anticorrupção Brasileira, em adotar programas de integridade e políticas de compliance anticorrupção (FOLHA DE SÃO PAULO, 2017).

Para tanto, passaram a implementar os chamados Programas de Integridade, que é o conjunto de mecanismos e procedimentos internos de integridade, auditoria e incentivo à denúncia de irregularidades, bem como à aplicação efetiva dos códigos de ética e de conduta, políticas e diretrizes da empresa, com o objetivo de detectar e sanar desvios, fraudes, irregularidades e atos ilícitos praticados contra a administração pública, nacional ou estrangeira (CGU; 2019)

O fato é que, dentre essas empresas, observou-se um movimento contundente em relação ao setor elétrico na adoção dessas medidas. Referido movimento, liderado pelas distribuidoras de energia elétrica, foi gerado principalmente pela importância estratégica do setor que, em virtude dos números econômicos que sustenta e também da sua natureza essencial, necessita posicionar-se perante o mercado, assumindo o papel de protagonista no cenário de criação de uma cultura de integridade no país (CARREIRO, 2019).

Essa tendência pode ser constatada ao se verificar o quadro das 23 empresas brasileiras que possuem o Selo Empresa Pró-Ética ${ }^{6}$, que avalia o Programa de Integridade as empresas, cuja última divulgação ocorreu em 2017 pela Controladoria Geral da União (CGU).

\footnotetext{
${ }^{6}$ O Selo EmpresaPró-Ética é a mais importante certificação de mercado para empresas que adotam práticas anticorrupção e políticas de Compliance. Tal conceito também será mais bem detalhado no Capítulo 4.
} 
Deste modo, com base nas informações divulgadas pela CGU, verifica-se que das 23 empresas que receberam o selo Empresa Pró-Ética, 7 pertencem ao setor elétrico, sendo 4 distribuidoras. Assim, dentre as diversas atividades econômicas refletidas pelas empresas que a possuem, constata-se que mais de $30 \%$ delas são provenientes do SEB, o que representa um número muito maior do que aquele observado em relação aos demais segmentos econômicos. Nesta seara, verifica-se que as principais distribuidoras de energia elétrica no país vêm se dedicando à construção desta cultura de integridade, buscando obter a respectiva certificação de integridade.

Assim, na medida em que as empresas distribuidoras de energia elétrica vêm se destacando no cenário nacional pela adoção de práticas reconhecidas de compliance anticorrupção, conforme estatísticas acima trazidas, principalmente pela implementação de programas de compliance ou ainda de Programas de Integridade, é enriquecedor para o tema fazer uma avaliação de como essas empresas estão estruturando os seus respectivos programas, com ênfase no segundo. Com isso, será possível detectar não só se eles estão em conformidade com a legislação pertinente, mas também se os critérios utilizados nessa implementação são suficientes para evitar não-conformidades de integridade.

\subsection{Objetivos, Questão Central e Hipótese}

Diante do cenário acima exposto, o objetivo principal desta dissertação é analisar os Programas de Integridade de duas das maiores distribuidoras de energia com base nos ditames da Lei Anticorrupção Brasileira (LAB) e nas instruções normativas da Controladoria Geral da União (CGU). Adicionalmente, o trabalho visa a atender os seguintes objetivos secundários: (i) descrever as características da problemática de corrupção que atingiu o país nestas duas últimas décadas, mais precisamente a partir de 2001; (ii) analisar a evolução da legislação anticorrupção no país; e (iii) avaliar a forma de implementação de Programas de Integridade nas empresas brasileiras. 
Alinhada a esses objetivos, pode-se dizer que esta dissertação busca responder a seguinte questão central: os critérios utilizados na implementação de Programas de Integridade, pelas distribuidoras de energia elétrica, são suficientes para evitar não-conformidades de integridade? Ademais, a hipótese a ser investigada por meio da análise realizada nos próximos capítulos é a de que os Programas de Integridade das distribuidoras pesquisadas não estão em completa conformidade aos ditames da Lei Anticorrupção Brasileira e das orientações da Controladoria Geral da União. Assim, será investigado se tais Programas possuem ou não lacunas e pontos de não-conformidade.

\subsection{Metodologia}

A metodologia utilizada na construção da presente dissertação contemplou quatro fases distintas: Primeiramente, o entendimento do problema. $\mathrm{Na}$ sequência, a organização e classificação da bibliografia atinente ao tema tratado. Após, realizou-se a pesquisa e o levantamento, perante duas das maiores distribuidoras de energia elétrica do país, da metodologia e dos processos aplicados na implementação dos seus respectivos Programas de Integridade. Finalmente, efetivou-se a avaliação dos Programas de Integridade das distribuidoras pesquisadas, sob a ótica da legislação anticorrupção e das orientações da Controladoria Geral da União.

Além disso, o tema tratado, seu contexto e estruturação para fins deste trabalho, foi exposto através de sete capítulos, expostos de forma interligada e subsequente. Assim, considerando que o primeiro capítulo é introdutório, o segundo capítulo tratará do problema da corrupção e de como ela se tornou endêmica no Brasil. Neste sentido, será abordada como a corrupção é vista sob o prisma de diversos autores como uma doença social, que atingiu a condição de endemia ao propagar-se em diversas atividades do país, trazendo sintomas e consequência muito prejudiciais para a economia e para a sociedade como um todo.

Para tanto, serão trazidos à baila seus vários conceitos e modalidades de classificação, bem como o seu histórico e evolução em âmbito nacional e 
internacional, abrangendo as origens documentadas no Brasil e no mundo, por ordem de relevância cronológica, até os registros mais recentes contemplando os maiores casos de corrupção constatados no país. Na sequência, será feito um breve relato sobre a Operação Lava-Jato, considerada, conforme já relatado, como a operação policial responsável por investigar e combater o segundo maior caso de corrupção já documentado na história mundial. O capítulo primeiro se encerra com uma explanação e análise sobre o Índice de Percepção da Corrupção (IPC) e o surgimento de uma grave crise de credibilidade e todas as consequências decorrentes desse fato.

O terceiro capítulo, por sua vez, trata da legislação anticorrupção e do seu regramento no Brasil e no mundo. Para tanto, primeiramente traz um histórico das principais normas internacionais de combate à corrupção, abordando as três mais importantes convenções supranacionais de integridade, instituídas respectivamente pela Organização para a Cooperação e Desenvolvimento Econômico (OCDE), pela Organização dos Estados Americanos (OEA), e pela Organização das Nações Unidas (ONU). Após, discorre sobre as duas legislações estrangeiras mais relevantes, sob o ponto de vista da influência econômica para o mundo: o Foreing Corrupt Practices Act (FCPA) norteamericano, e o United Kingdom Bribery Act (UKBA) britânico. Ao final, traz um compilado sobre a legislação anticorrupção brasileira.

O quarto capítulo trata do compliance de integridade. Nele aborda-se o conceito clássico de compliance e os demais conceitos correlatos, necessários à compreensão do tema e de sua importância no atual cenário. Além disso, o terceiro capítulo expõe as diferentes modalidades de programas que podem ser implementados nas empresas, objetivando a fixação de diretrizes de integridade e o combate à corrupção. Por fim, esse capítulo discorre sobre o mais relevante dos programas de compliance de integridade e sua respectiva certificação: o Programa de Integridade, cujas diretrizes foram trazidas pela Lei $n .{ }^{0} 12.846$, de 01 de agosto de 2013, conforme alterada pelo Decreto n. ${ }^{\circ} 8.420$, de 18 de março de 2015, e regulamentadas pela Controladoria Geral da União. 
O quinto capítulo visa a contextualizar as distribuidoras de energia elétrica no cenário econômico nacional, com o objetivo de demonstrar a necessidade de protagonismo dessas empresas na criação de uma cultura de integridade. Para tanto, traz um breve histórico das distribuidoras, demonstrando, em números e estatísticas, a importância econômica desse segmento da cadeia de provimento de energia elétrica.

O sexto capítulo traz a materialização efetiva proposta por este trabalho: uma análise do Programa de Integridade de duas das maiores distribuidoras de energia elétrica do país, objetivando verificar o grau de conformidade com que foram implementados e a existência de eventuais lacunas e ou inconsistências. Tal tarefa será realizada tomando como referência a Lei Anticorrupção Brasileira.

Por fim, o sétimo capítulo traz as considerações finais do trabalho, com a análise dos resultados obtidos e as conclusões. 


\section{CAPÍTULO 2. RESUMO HISTÓRICO DA CORRUPÇÃO E SEUS}

RESPECTIVOS EFEITOS

Como já mencionado, este capítulo se dedica explanar sobre o problema da corrupção e sua endemia, discorrendo sobre seus vários conceitos e modalidades de classificação, bem como o seu histórico e evolução em âmbito nacional e internacional, inclusive sobre a Operação Lava-Jato. Finaliza expondo os efeitos nocivos da corrupção e refletindo sobre a crise de credibilidade que se instalou no país.

\subsection{Conceito e Classificação da Corrupção}

Corrupção, conforme sua acepção literal da palavra, é o efeito ou ato de corromper alguém ou algo, com a finalidade de obter vantagens em relação aos outros por meios considerados ilegais ou ilícitos. Etimologicamente, o termo "corrupção" surgiu a partir do latim corruptus, que significa o "ato de quebrar aos pedaços", ou seja, decompor e deteriorar algo. A ação de corromper pode ser entendida também como o resultado de subornar, dando dinheiro ou presentes para alguém em troca de benefícios especiais de interesse próprio (SIGNIFICADOS, 2019).

A corrupção é um meio ilegal de se conseguir algo, sendo considerada grave crime em alguns países. Normalmente, a prática da corrupção está relacionada com a baixa instrução política da sociedade, que muitas vezes compactua com os sistemas corruptos. A corrupção na política pode estar presente em todos os poderes do governo, como o Legislativo, Judiciário e Executivo. No entanto, a corrupção não existe apenas na política, mas também nas relações sociais humanas, como o trabalho, por exemplo.

Segundo Gianfranco Pasquino (2009; p.291), conforme definição compilada pelo Dicionário de Política, organizado por Norberto Bobbio, corrupção seria o fenômeno pelo qual um funcionário público é levado a agir de modo diverso dos padrões normativos do sistema, favorecendo interesses particulares em troca de recompensa. 
Já de acordo com Tercio Sampaio Ferraz Junior (2017; p.15), o conceito de corrupção seria mais instintivo do que propriamente científico, já que ninguém é capaz de dizer exatamente o que ela é. Mas, quando ela aparece, qualquer um sabe do que se trata. Ainda em sua visão, embora, nos dias de hoje, corrupção seja um tema corrente, tratado na legislação e verberado moralmente, é possível dizer que talvez não se trate propriamente de um problema jurídico, nem mesmo, em sua essência, de um problema ético, mas de um mito político. Não se trataria, assim, de um conceito descritivo, mas de um conceito valorativo: é impossível separar com nitidez o fato da indignação que ele provoca.

No mesmo sentido, ou seja, adotando-se a corrupção como um fenômeno político, ela pode ser definida como um conceito normativamente dependente, ou seja, oriundo das regras e princípios que estruturam a vida política. Neste diapasão, o ato de corrupção dependeria da verificação concreta de uma situação que, de algum modo, ofenda às normas socialmente impostas. (FILGUEIRAS, 2011).

Sérgio Habib (1994, p. 147-148), por outro lado, considera o conceito de corrupção bem mais abrangente, na medida em que haveria uma série de outras condutas, não necessariamente denominadas especificamente como corrupção, que mereceriam essa conotação. Para tanto, descreve que há no direito penal positivo, outros tipos que, conquanto não apresentem expressamente o nomem juris 'corrupção', sugerem que possam ocorrer condutas maculadas também por ela. Assim, poder-se-ia alinhar em relação ao conceito de corrupção, as seguintes figuras penais: exploração de prestígio, sonegação de papel ou objeto de valor probatório, patrocínio infiel, violação de sigilo funcional, abandono de função, advocacia administrativa e prevaricação.

Por outro lado, existiria uma gama bastante abrangente das várias conotações de corrupção, já que os diversos conceitos de corrupção envolveriam alguns aspectos comuns sugeridos pela respectiva ótica científica de abordagem ou ainda pelos sentidos do próprio vocábulo. Neste sentido, poder-se-ia englobar dentre esses aspectos abrangidos pelo conceito de corrupção, ainda, a alteração 
morfológica de alguma coisa; a desagregação material ou moral; a decomposição de um todo em partes sem elo comum; o esgarçamento do sentido coletivo das coisas; o menosprezo pela vontade social contida na lei; a sobreposição de bem privado de natureza particular, setorial ou grupal, em relação ao bem comum; o distanciamento entre o agir real e o agir normativo (desvio normativo); o bem privado traduzido por vantagem econômica ou não; a diferenciação socioeconômica entre os personagens da corrupção, com ascendência do corruptor sobre o corrompido; a indiferença ou cumplicidade do corrompido, conforme o caso; e, finalmente, a ausência de substrato ético (FAZZIO JUNIOR, 2019).

Franco Cazzola (1998; p. 12), de outro lado, entende que a corrupção poderia ser conceituada a partir da utilização de três diferentes critérios. O primeiro, também denominado de critério legalístico, crava que um comportamento político é corrompido quando viola um standard formal ou uma regra de comportamento predisposta por um Sistema. Assim, o ato de corrupção seria tipificado pela violação à lei positivada, à norma utilizada como diretriz formal.

O segundo, denominado critério do interesse público, parte da premissa de que um sistema de ordem pública e civil exalta o interesse comum colocando-o acima dos interesses particulares. Deste modo, transgredir o interesse comum em benefício de interesses de cunho particular seria tipificar um ato de corrupção. 0 terceiro e último critério, por sua vez, denominado critério da opinião pública, diz que seria corrupção tudo aquilo que vem considerado como tal pela opinião pública.

Percebe-se, portanto, que o conceito de corrupção está sempre atrelado a uma ideia de algo que não está em estado íntegro, que foi corrompido sob o ponto de vista moral, que não detém a incolumidade de sua integridade. Todavia, e exatamente por haver uma área extensa entre os seus vários significados, percebe-se que o conceito de corrupção, sob o ponto de vista da sociedade, como um todo, acaba invadindo outras searas interligadas, como a seara da ética, da moral e dos bons costumes, por exemplo. 
Neste sentido, um proveitoso estudo foi realizado por Heidenheimmer, Johnston e Levine (1970. p. 3-6), que nos anos 1970 utilizaram os índices de reprovação da opinião pública para classificar a corrupção em três espécies principais, divididas entre corrupção negra, corrupção cinza e corrupção branca. O estudo foi realizado com base em entrevistas feitas diretamente com a população, cujo objetivo era o de verificar como estariam classificados determinados atos hipotéticos praticados pelas pessoas.

O estudo trouxe situações praticadas cotidianamente e que variavam entre atos de corrupção clássica e outras situações mais comuns, praticadas por pessoas no dia a dia de seus afazeres e, cujo viés, seria mais ligado à seara dos costumes, conforme discorrido e ilustrado na Figura 1.

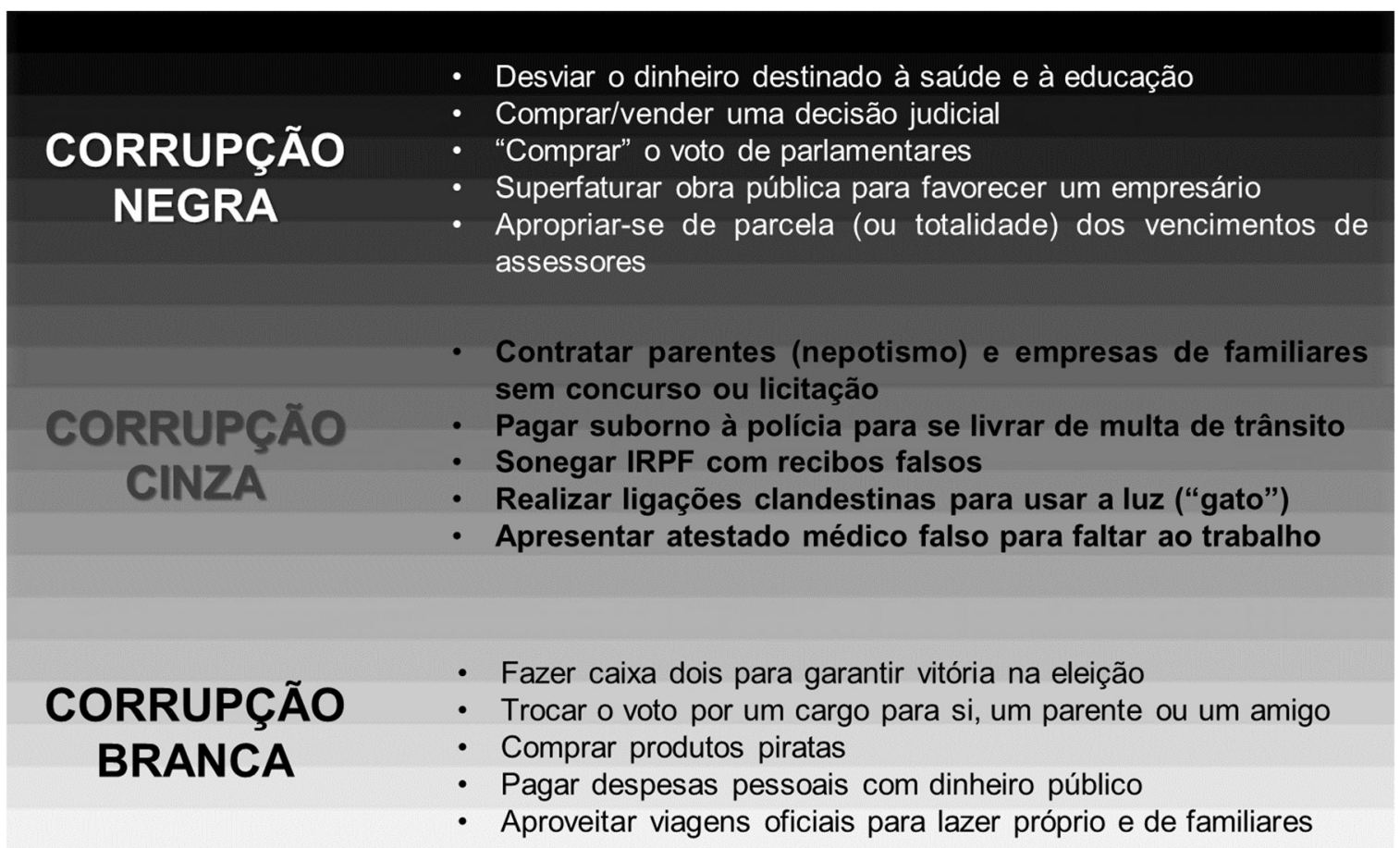

Figura 1 - Quadro de Heidenheimmer

Fonte: HEIDENHEIMMER, Arnold J. Political corruption: readings in comparative analysis. New York: Holt, Rinegart and Winston, 1970. p. 3-6. (Tradução Livre).

Deste modo, seguindo-se os parâmetros do quadro criado por Heidenheimmer, a primeira classificação seria a chamada corrupção negra, que compreenderia 
as práticas consideradas mais graves, ordinariamente reprimidas pelo direito penal, em sua grande parte caracterizadas pelo conceito legalístico de corrupção. Neste sentido, a maioria dos eventos identificados como sendo de corrupção negra traz o envolvimento do Poder Público e um sentimento claro de obtenção de vantagem privada, individual, em detrimento do bem-estar coletivo, que envolve a tutela do interesse público.

Na sequência, temos a denominada corrupção cinza, que compreenderia as práticas que são condenadas pela opinião pública, mas de alguma forma toleradas pela sociedade. Nesse caso, estariam refletidos atos de financiamento clandestino a setores públicos, por um empresariado preocupado com a defesa de seus interesses, e que na condição de integrantes de uma coletividade, precisariam lidar com problemas teoricamente mais graves. Como consequência, os demais membros da sociedade acabam aceitando atos de corrupção que os beneficiariam como comunidade.

A corrupção branca, por sua vez, compreenderia em quase sua totalidade as práticas que não são consideradas como atos de corrupção propriamente ditos, isto é, sob a ótica do conceito clássico, abrangendo práticas antiéticas e que feririam a moral e os bons costumes. Essas práticas, porém, são amplamente toleradas pela sociedade e inclusive vistas como naturais e benignas, na medida em que serviriam para conceder isonomia e equilíbrio às injustiças sociais. Enquadram-se nessas práticas a troca de favores e os atos realizados para a consumação de pequenas vantagens.

Deve ser feita a ressalva, por óbvio, no sentido de que o estudo trazido à baila é datado dos anos 70, ou seja, em âmbito de uma sociedade que aceitava esse tipo de prática de uma maneira mais casual e permissiva. Talvez essa mesma pesquisa, se realizada nos dias de hoje, trouxesse um resultado bastante diferente, pois as práticas ali refletidas já não são mais aceitas com tanta naturalidade, nem pelo indivíduo, nem pela coletividade. 


\subsection{Resumo Histórico da Corrupção no Brasil e no Mundo}

A corrupção sempre esteve presente na história da humanidade. Seus registros são datados da pré-história à idade contemporânea, nas mais diversas situações e sociedades. Para demonstrarmos o quão profundo é o problema da corrupção na sociedade humana, faz-se necessário trazer um breve histórico cronológico de como ela foi vista e tratada através dos tempos, primeiramente sob o ponto de vista dos registros da corrupção pelo mundo e, na sequência, dos fatos ocorridos e registrados em terras brasileiras.

Entende-se de que desde que o homem surgiu, e com ele e suas necessidades, surgiu também a corrupção. Nesse caso, a sociedade, que se organizava social, política e economicamente sob o tipo familiar, tribal ou em clãs, não registrava ainda a corrupção pública, já que não havia uma organização de "estado" para assim tipificá-la. Mesmo a partir de 3500 a.C., no Egito antigo, ainda não há registro de documento jurídico escrito, ou de classificação para corrupção. Os registros históricos apontam que os Faraós quem ditavam o "direito" das pessoas, sob "inspiração divina” (VIRTUOUS, 2019).

O próprio Código de Hamurabi, oriundo da Babilônia (1772 a.C.), estabelecia sanções para falso testemunho, roubo, estupro e não cumprimento das obrigações, mas não punia expressamente atos de corrupção, limitando-se a citar apenas sanções para o juiz que, ao dar publicidade as suas decisões, alterasse seu julgamento posteriormente (VIRTUOUS, 2019).

Somente na antiguidade clássica (Sec. VIII a.C. ao Sec. IV a.C.), que surgiram os primeiros registros. $\mathrm{Na}$ Grécia Antiga, sob a formação das cidades-estados (polis), Aristóteles (2016; p. 136), no livro sobre a geração e a corrupção, já discorria sobre a corrupção das espécies, na geração dos corpos. Segundo o filósofo, aquilo que se gera e se corrompe, seria fruto da metamorfose natural que se processa na microestrutura do ser. Assim, o processo de corrupção seria oriundo da própria transformação do ser humano, como um processo natural de sua existência e de sua sobrevivência. 
Ainda segundo Aristóteles (2016; p.235), em sua obra Ética a Nicômaco7, existiam ainda dois pontos a serem observados na evolução da corrupção: a chamada corrupção dos costumes (refletida na obra pela acusação, a Sócrates, por corromper a juventude, no sentido de perder a crença nos deuses da cidade); e o conceito de déspota, que seria aquele que persegue seu interesse no âmbito de um sistema tirano, oligárquico e demagógico. Depreende-se, portanto, que Aristóteles documentava sua visão da corrupção pela divisão do poder em bom (onde existia o interesse comum) e ruim (onde existia o interesse individual).

Na República Romana (Sec. IV a.C. ao Sec. I a. C.), o orador e político romano Cícero (2019; p.3-16), se dedicava a fomentar a ética e combater a corrupção. Dizia que a honestidade consiste em descobrir a verdade pela astúcia do espírito, ou em manter a sociedade humana dando a cada um o que é seu e observando fielmente as convenções. Produziu, ainda, as Catilinálias (ano 63 a.C.), que foi uma série de discursos que procurou desmascarar as tramas, conspirações, corrupções e excessos pessoais de Lucio Sergio Catilina, senador romano, e seus seguidores.

Avançando para o período de 476 d.C. a 1.453 d. C., e conforme ensinado por Fernando Filgueiras (2008, p. 55), a Idade Média também assistiu a uma mudança conceitual da temática da corrupção, uma vez que o pensamento político estaria marcado pelo dogma cristão e pela existência de uma ontologia cindida entre dois mundos. De um lado, há a mundanidade infinita, pertencente ao reino de Deus, capaz de assegurar, de acordo com Santo Agostinho, as devidas virtudes capazes de gerar a integridade de uma república. De outro lado, a par do mundo sagrado, existe a mundanidade finita, pertencente ao reino dos homens, na qual a corrupção, traduzida como o luxo e a cobiça, desempenha o papel de redenção à fé cristã, além de fazer parte da condição decaída em que se encontravam os homens.

No período de 1.469 d.C. a 1.527 d. C., Nicolau Maquiavel (2008, p. 1-218) já dizia que a natureza humana é essencialmente má. Os seres querem os

\footnotetext{
${ }^{7}$ As obras de Aristóteles, embora muito antigas, são encontradas na rede mundial de computadores ou publicadas por editoras em novas edições.
} 
máximos ganhos a partir do menor esforço. E só fazem o bem quando forçados a isso. Na sua maior obra, denominada O Príncipe, Maquiavel descreve as formas de poder e as formas como um "príncipe" deve governar, discorrendo sobre como a corrupção pode afetar um dos agentes políticos (o povo, os grandes ou o príncipe) ou todos eles. Mas o termo ganha conotação de sobreposição do interesse individual em detrimento do bem comum ou à falta de habilidade política.

Neste sentido, algumas reflexões devem ser feitas: primeiramente, a corrupção do povo encontra sua origem na corrupção de seus governantes. Todavia, permanece a questão se existiria a possibilidade de reordenação da república e sua recondução à vida livre, ainda que o povo estivesse corrompido. Maquiavel faz concluir que sim, desde que o cidadão virtuoso se disponha a realizar as reformas necessárias.

Em 1621, o político e filósofo Francis Bacon, que serviu como ministro ao rei da Inglaterra, Jaime I, e dele recebeu o título de visconde, foi denunciado no parlamento inglês por corrupção. E isso já num sentido moderno, ou seja, de apropriação de dinheiro público. Confessou ter recebido presentes das partes num tribunal que presidia, mas jurou que nenhum suborno afetou suas decisões. Foi perdoado, mas deste fato resultou o encerramento de sua carreira política.

Na era moderna, a história da corrupção foi marcada pelo caso Lockheed, onde uma das maiores companhias de construção e comercialização de aviões do mundo, que teve um crescimento exponencial contundente de 1950 a 1970, distribuiu mais de US $\$ 300$ milhões em comissões e propinas (que em valores atuais chegam a US\$3,6 bilhões. O caso veio à tona e trouxe consequências consideradas modestas: o presidente e o vice-presidente da empresa renunciaram a seus cargos em 1976, porém ninguém foi preso ou processado (ARAÚJO, 2015).

O episódio internacional de corrupção mais conhecido, no entanto, foi o caso Watergate. (G1 Educação; 2017). Durante a corrida presidencial nos EUA entre o candidato democrata e o candidato republicano, houve o arrombamento do 
escritório do partido democrata no edifício Watergate. Com o início das investigações pelo Federal Bureau of Investigation - FBI, veio à tona a descoberta de uma série de doações para fins políticos, as quais revelaram um grande esquema de pagamentos indevidos a funcionários públicos estrangeiros.

Houve então a prisão dos participantes e a confirmação do envolvimento do presidente Nixon, o que levou a um processo de Impeachment e à sua renúncia. $\mathrm{O}$ caso foi tão contundente e causou tamanha repercussão que deu origem à primeira versão da legislação anticorrupção norte-americana, o FCPA, focada na manutenção de livros e registros financeiros precisos, na implementação de controles contábeis internos adequados e na adoção de disposições antissuborno.

No Brasil, o primeiro registro de corrupção foi verificado no Brasil Colônia (ano 1500 a 1822), onde Pêro Vaz de Caminha, em carta ao Rei D. Manuel I, pede para que seu genro, Jorge de Osório, seja libertado da prisão e do degredo, o qual havia sido condenado por roubar uma igreja e surrar o padre (MARCEL, 2016). Ainda nesse período, Pêro Borges, o primeiro Ouvidor-Mor do Brasil Colônia, foi condenado em Portugal por receber indevidamente quantias provenientes das obras de um aqueduto, correspondente a metade da verba destinada para a obra e ao valor de um ano de salário como servidor público.

Diversos outros casos de corrupção foram constatados na época do Brasil Colônia, como o caso da Capitania de Goiás, cujo novo governador deveria investigar indícios de improbidade e corrupção generalizados e teve suas intenções frustradas pelo tráfico de influência do antigo governador.

A corrupção no Brasil Colônia possui algumas teses, como a de que houve sua acentuação pelo fato de ter havido uma colonização "sui generis". Neste diapasão, é sabido que o povoamento inicial do Brasil foi realizado pelos chamados degredados. Aportaram na colônia, para colonizar as novas terras, todos aqueles que não dispunham de maiores perspectivas em sua terra natal, os degredados, os incorrigíveis, os falidos de qualquer sorte, inexistindo, por 
assim dizer, compromisso moral ou ideológico em construir uma nação, em formar um povo (HABIB; 1994).

Além disso, a base de produção era escravista, de modo que a mão de obra utilizada era basicamente de escravos trazidos da África e índios locais, já que se tratava de colônia meramente extrativista. Assim, não havia dignidades preestabelecidas, nem valores de princípios, prevalecendo a lei da vantagem, tipificada pela troca de favores, tráfico de influência, conchavo, apadrinhamento, sonegação e desvio de verba (HABIB; 1994).

No período do Brasil Império (ano 1822 a 1889), por sua vez, com a vinda da família real portuguesa para o país, em 1808, instituiu-se uma corrupção mais requintada, proveniente de nobres, ministros e ocupantes do governo, que promoviam trapaças e negócios escusos visando lucro fácil (BBC BRASIL; 2012).

No período do Brasil na Velha República (1889 a 1930), houve a estratificação do "Coronelismo", caracterizado pela relação escusa entre políticos nacionais, governantes e coronéis buscando troca de favores, apadrinhamento, protecionismo, tráfico de influência e promovendo os chamados "votos de cabresto", garantindo os votos na época de eleição através de fraudes eleitorais (ANDRADE NETO; 2018). Com isso, houve o preenchimento de cargos públicos através de indicações políticas, estimulando a fraude, preterindo-se direitos, cometendo abusos e praticando injustiças.

No Brasil da Era Vargas (1930 a 1945), período em que a presidência de república era ocupada por Getúlio Vargas, embora tenha havido avanços significativos no campo dos direitos trabalhistas e sociais, no âmbito da corrupção também houve eventos significativos, podendo-se tomar como exemplo a acusação feita ao próprio Getúlio Vargas, à época de seu suicídio, de ter liberado um empréstimo do Banco do Brasil para que fosse criado o jornal Última Hora, que era o único da grande imprensa que o defendia (CARVALHO, 2013). 
No período do Brasil na República Nova (1946 a 1964), a União Democrática Nacional (UDN), partido de oposição ao legado getulista, consolidou-se como um movimento conservador com discurso moralista contra a corrupção e forte tendência anticomunista (BEZERRA; 2011). No entanto, enquanto os partidos políticos apregoavam nos palanques a necessidade de se combater a corrupção, nos bastidores corrompiam eleitores, fraudavam apurações, selavam pactos imorais, prometiam concessões.

Dentre os períodos pré-contemporâneos, todavia, o período do Brasil na Ditadura Militar (1964 a 1985) foi efetivamente aquele que publicamente revelou os casos mais evidentes de corrupção. Podemos citar vários casos, começandose pela liquidação arbitrária da companhia aérea Panair do Brasil (SASAKI, 2015), em 1965, até a ocorrência de outros casos bastante conhecidos, como o da Magnesita, de $1972^{8}$; o caso do favorecimento da Camargo Correa na Central Geradora Hidrelétrica Água Vermelha, de 1974, realizado pelo então ministro da economia Delfim Neto; e o caso Lutfalla, de 1977, quando houve denúncias contra Paulo Maluf e Reis Veloso por irregularidades na concessão de empréstimos por meio do BNDES (FREIRE, 2015).

Além disso, podem ser citados, ainda, o caso do grupo CAPEMI, de 1980, que fez empréstimos com bancos estrangeiros, não cumpriu os acordos e, à beira da falência, conseguiu que os valores devidos fossem pagos pelo Banco Nacional de Créditos subordinado ao Ministério da Agricultura (ILG; 2017); o escândalo da mandioca, de 1981, com o desvio de $\operatorname{Cr} \$ 1,5$ bilhão do Banco do Brasil, destinado ao Programa de Incentivo Agrícola do governo federal, entre outros (MPF; 2019).

Foi do período do Brasil na Nova República ou Contemporâneo (1985 até os dias de hoje), no entanto, que os casos de corrupção se tornaram mais divulgados e passaram a ser vistos de uma forma nociva à sociedade. O primeiro caso com destaque foi o impeachment do então presidente da república Fernando Collor

\footnotetext{
${ }^{8}$ Onde o político Antonio Carlos Magalhães foi acusado de abater 50\% das dívidas da empresa Magnesita, da qual era acionista.
} 
de Mello, em 1992, que adveio da descoberta de manipulação de contratos, contas fantasmas e desvio verbas (BEZERRA; 2011).

No período de 1993 a 1994 houve outro caso bastante difundido, os chamados "Anões do Orçamento", onde houve a concessão de subvenções sociais para entidades filantrópicas em nome de terceiros e acertos com grandes empreiteiras para a inclusão de verbas orçamentárias para grandes obras, com preços acima do praticado no mercado, em troca de comissões. Em 2001 houve o caso conhecido como "Máfia dos Sanguessugas", com o superfaturamento de ambulâncias e provisionamentos médicos em detrimento do poder público (SARDINHA, 2012).

No período de 2004 a 2008 houve a operação policial conhecida como Satiagraha, onde foi efetuada a apuração de corrupção e lavagem de dinheiro, evasão de divisas e concessão de empréstimos ao grupo Opportunity (Attuch; 2012). Os dois casos de corrupção mais relevantes do período contemporâneo brasileiro são, no entanto, o caso do "Mensalão" (2005 a 2008), conhecido como o escândalo de corrupção política mediante a compra de votos de parlamentares no Congresso Nacional do Brasil (DARIE; 2018); e o "Petrolão" (2014), que foi o esquema de corrupção e desvio de fundos que ocorreu na Petrobras, a maior empresa estatal brasileira, exposto pela Operação Lava Jato (FREITAS; 2015).

Faz-se mister ressaltar a relevância dos dois últimos casos citados para o contexto da corrupção, no Brasil. No caso do Mensalão, por ter sido a primeira investigação de corrupção que apurou responsabilidades e realmente puniu os acusados com condenações criminais. Tem-se como exemplo o ex-ministro da Casa Civil, José Dirceu, que foi efetivamente responsabilizado pelos crimes de corrupção e condenado a cumprir pena. O Petrolão, por outro lado, já é considerado como o grande divisor de águas nos casos de corrupção no país, pois rompeu paradigmas em relação a condenação de grandes empresas, personalidades sociais importantes e políticos, inclusive chefes de estado. 


\subsection{A Operação Lava Jato e seus desdobramentos}

A Operação Lava Jato constitui-se de um conjunto de investigações em andamento pela Polícia Federal do Brasil, que cumpriu mais de mil mandados de busca e apreensão, de prisão temporária, de prisão preventiva e de condução coercitiva, visando apurar um esquema de lavagem de dinheiro que movimentou bilhões de reais em propina (WIKIPEDIA; 2019).

Ela teve início em 17 de março de 2014 e conta até agora com 61 fases operacionais, durante as quais mais de cem pessoas foram presas e condenadas. Investiga crimes de corrupção ativa e passiva, gestão fraudulenta, lavagem de dinheiro, organização criminosa, obstrução da justiça, operação fraudulenta de câmbio e recebimento de vantagem indevida. Os números da Lava Jato impressionam e trazem uma reflexão bastante interessante: sua repercussão fez com que ela deixasse de ser apenas mais uma operação policial de combate à corrupção para se tornar a mais célebre ação de investigação de integridade já realizada no Brasil, conforme pode ser verificado na Figura 2.

\begin{tabular}{|c|c|}
\hline Procedimentos instaurados & 2476 \\
\hline Pessoas presas & 115 prisões preventivas, 121 temporárias e 6 em flagrante \\
\hline Mandados de buscas e apreensões & 962 \\
\hline Mandados de conduções coercitivas & 227 \\
\hline Pedidos de cooperação internacional & 513 \\
\hline Condenados & 203 \\
\hline Acordos com pessoas & 164 acordos de colaboração premiada \\
\hline Acordos com empresas & $\begin{array}{l}11 \text { acordos de leniência firmados e } 1 \text { termo de } \\
\text { ajustamento de conduta }\end{array}$ \\
\hline Acusações criminais & 78 contra 328 pessoas, e 43 sentenças \\
\hline Empresas envolvidas & 16 \\
\hline Acusações de improbidade administrativa & $\begin{array}{l}8 \text { contra } 50 \text { pessoas, } 16 \text { empresas e } 1 \text { partido político, } \\
\text { pedindo pagamento de } R \$ 14,5 \text { bilhões }\end{array}$ \\
\hline Desvio total estimado & $\mathrm{R} \$ 42,8$ bilhões \\
\hline Pagamento de propina & R\$̦ 6,4 bilhões confirmados, $R \$ 10$ bilhões estimados \\
\hline Pedido de ressarcimento & R\$ 38,1 bilhões \\
\hline Dinheiro recuperado & $\mathrm{R} \$ 12,3$ bilhões \\
\hline Dinheiro repatriado & R\$ 756,9 milhões \\
\hline Valores bloqueados em contas nacionais e estrangeiras & R\$ 3,2 bilhões \\
\hline Soma das penas condenatórias & 1983 anos, 4 meses e 20 dias de pena \\
\hline
\end{tabular}

Figura 2 - Estatísticas da Operação Lava Jato

Fonte: página da Wikipedia; 2019. 
Para uma melhor compreensão da importância histórica da Operação Lava Jato cabe fazer um breve resumo sobre os fatos ocorridos durante a realização das investigações e os seus respectivos desdobramentos, ano a ano, desde o seu início até os dias atuais.

Assim, tendo como abertura o ano de 2014, onde se desenrolaram as fases 1 a 7 da operação, foram efetuadas dezessete detenções, incluindo a do doleiro Alberto Youssef e do à época Diretor de Abastecimento da Petrobras, Paulo Roberto Costa, por envolvimento no esquema de corrupção. A descoberta do envolvimento do Sr. Paulo Roberto Costa no esquema de corrupção, deu início formal ao escândalo do Petrolão (FOLHA DE SÃO PAULO, 2014).

O ano de 2015 , onde se desenrolaram as fases 8 a 21 da operação, foi o mais movimentado em termos de ações praticadas pela polícia federal, prisões efetuadas e delações realizadas. Em março deste referido ano, o Supremo Tribunal Federal - STF autorizou a investigação de doze senadores e vinte e dois deputados por corrupção na Petrobras, entre eles os presidentes das duas câmaras, que integravam a coalizão de governo. Na sequência, foram realizadas as condenações de Paulo Roberto Costa e Alberto Youssef, que se tornaram delatores para buscar reduções em suas penas em troca de informação.

Em maio, o ex-chefe da área internacional da Petrobras, Nestor Cerveró, é condenado a cinco anos de prisão por lavagem de dinheiro (G1 RIO; 2015). Em junho foram detidos os empresários Marcelo Odebrecht e Otavio Marques de Azevedo, presidentes das construtoras Odebrecht e Andrade Gutierrez, duas das maiores empreiteiras do país, acusados de participação no esquema de corrupção e pagamento de suborno (VIEIRA, 2015).

Em julho, a justiça condenou os principais diretores da construtora Camargo Correa, Dalton Avancini e Eduardo Leite. Em agosto, o ex-ministro José Dirceu, ex-chefe de gabinete de Lula, é detido e a procuradoria o acusa de ser um dos líderes do esquema de corrupção na Petrobras. Nesse mesmo mês de agosto, o procurador-geral da República denuncia que o presidente da Câmara dos Deputados, Eduardo Cunha, que havia recebido pelo menos cinco milhões de 
dólares em suborno no esquema e também o ex-presidente Fernando Collor, por suposto envolvimento no esquema.

Em setembro, o tesoureiro do PT, José Vaccari Neto, acusado de quarenta e quatro delitos de lavagem de dinheiro e detido desde abril, foi condenado a quinze anos e quatro meses de prisão (G1 PR; 2015). Renato Duque, ex-diretor de Serviços da Petrobras, foi condenado a mais de vinte anos de prisão nessa mesma data. Em novembro, o senador do Partido dos Trabalhadores, Delcídio Amaral, líder do governo no Senado, foi acusado de obstruir as investigações e o banqueiro André Esteves, presidente do BTG, o maior banco de investimentos da América Latina, também foi detido.

No ano de 2016, onde se desenrolaram as fases 22 a 37 da operação, o exdiretor da área internacional da Petrobras, Jorge Zelada, foi condenado a doze anos e dois meses de prisão por corrupção e lavagem de dinheiro, assim como o principal encarregado pela publicidade das campanhas presidenciais de Dilma Rousseff e Luiz Inácio Lula da Silva, João Santana (RANGEL, 2016), e sua mulher, foram detidos para esclarecer se os milionários pagamentos recebidos do exterior provinham de uma construtora e de um operador financeiro, ligados ao esquema montado na Petrobras. A partir deste momento, começaram as investigações em torno do ex-presidente Lula (FREIRE; 2016).

No ano de 2017, por sua vez, onde se desenrolaram as fases 38 a 47 da operação, houve várias intervenções da justiça no sentido de se promover intercâmbios com outros países, objetivando a abertura de informações sigilosas e o bloqueio de contas e valores (ANTAGONISTA; 2016). Neste sentido, a Suíça chegou a bloquear o equivalente a mais de três bilhões de reais relacionados a contas bancárias de pessoas investigadas na operação.

Foram analisadas ainda mais de mil contas. Segundo o Ministério Público Federal "o processo coordenado entre Suíça, Brasil e EUA constituiu um sucesso para a luta internacional contra a corrupção". Em abril, um laudo da Polícia Federal apontou que a Odebrecht deu um prejuízo de 5,6 bilhões de reais à Petrobras. No mesmo mês, o ministro Edson Fachin, novo relator da Lava Jato 
no STF, retirou o sigilo dos 83 inquéritos contra políticos, dos depoimentos dos delatores da Odebrecht $(\mathrm{G} 1 ; 2017)$.

Em junho deste mesmo ano, Rodrigo Janot, Procurador Geral da República, denunciou Michel Temer pelo crime de corrupção passiva (G1; 2017), que se tornou o primeiro presidente do Brasil a responder por crime durante o mandato. Em agosto, a Polícia Federal prendeu o ex-deputado federal do PT, Cândido Vaccarezza $(\mathrm{G} 1$; 2017). Em setembro, a Polícia Federal fez uma busca em um apartamento ligado a Geddel Vieira Lima e apreendeu oito malas e quatro caixas de dinheiro vivo. A contagem totalizou mais de 51 milhões de reais, tendo sido a maior apreensão de dinheiro vivo da história do país (G1; 2018).

No ano de 2018 , onde se desenrolaram as fases 48 a 57 da operação, as investigações alcançaram licitação e obras da Usina Hidrelétrica de Belo Monte. De acordo com as investigações houve pagamento de propinas para políticos do PT e PMDB. Em maio, constatou-se propina de US\$ 56,5 milhões, a partir de contrato da Organização Odebrecht com a Petrobras. Os pagamentos, segundo o MPF, ocorreram entre 2010 e 2012, referentes a um contrato fraudulento de mais de US\$ 825 milhões. De acordo com o órgão, parte dos pagamentos de vantagens indevidas foram realizados por meio de estratégias de ocultação e dissimulação $(G 1,2018)$.

E finalmente no ano de 2019, onde se desenrolaram as fases 58 a 61 da operação, até o momento, houve o mandado de prisão preventiva, busca e apreensão contra o ex-governador paranaense Beto Richa (ANTAGONISTA; 2019). Concessionárias de pedágio e outras empresas teriam subornado o exgovernador em ao menos $\mathrm{R} \$ 2,7$ milhões. Em fevereiro houve a prisão de Paulo Vieira de Souza, conhecido como Paulo Preto, por lavagem de dinheiro (G1; 2017).

A Operação Lava Jato continua e estão previstas novas investigações, motivadas tanto por provas novas colhidas, quanto por delações premiadas. 


\subsection{I Índice de Percepção da Corrupção}

O Índice de Percepção da Corrupção (IPC), divulgado pelo órgão Transparência Internacional, é a mais duradoura e abrangente ferramenta de medição da corrupção no mundo. Ela existe desde 1996 e reúne, neste ano de 2018, resultados de 180 países e territórios, conforme pode ser visto na Figura 3. Também é a mais utilizada por tomadores de decisões nos setores público e privado para avaliar riscos e orientar suas ações (TRANSPARÊNCIA INTERNACIONAL; 2019).

Dos 180 países avaliados pelo índice de 2018 , mais de dois terços receberam uma nota abaixo de 50. Isso significa que mais de seis bilhões de pessoas vivem em países que, em tese, são corruptos. Neste sentido, faz-se mister efetuar uma observação no que diz respeito à relação entre corrupção e liberdade de expressão. Segundo a Transparência Internacional, liberdade de expressão é fundamental para expor a corrupção e as injustiças que ela causa.

Países com altas notas no IPC (aqueles com níveis mais baixos de corrupção) são muito melhores em proteger os direitos de jornalistas e ativistas. Inversamente, os de notas baixas (aqueles com níveis mais altos de corrupção) têm maior probabilidade de abafar as vozes de cidadãos e cidadãs e da mídia (TRANSPARÊNCIA INTERNACIONAL; 2019).

Todavia, vale consignar um primeiro ponto de atenção: percepção de corrupção não é igual a corrupção efetiva. Isso significa dizer que o índice mede a percepção da corrupção pelas pessoas, e não realmente o quanto ela está ocorrendo. Segundo Luiz Paulo Rosenberg (2016; p. 127), medir a crença e a percepção de corrupção ao invés de corrupção de fato, esbarra em inúmeras dificuldades técnicas e subjetivas, levando a questionamentos sobre a precisão dos indicadores de percepção. 

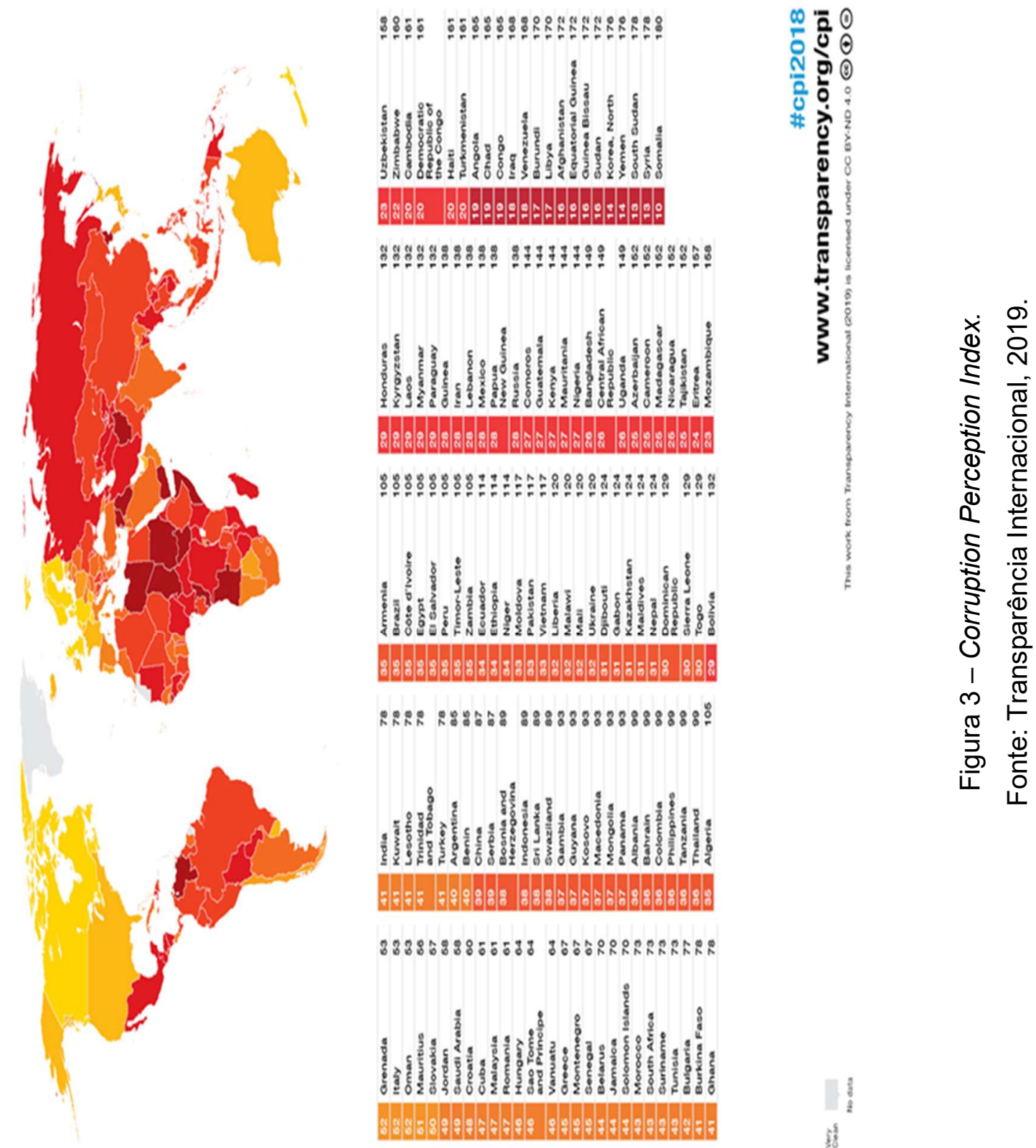

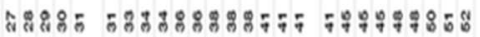
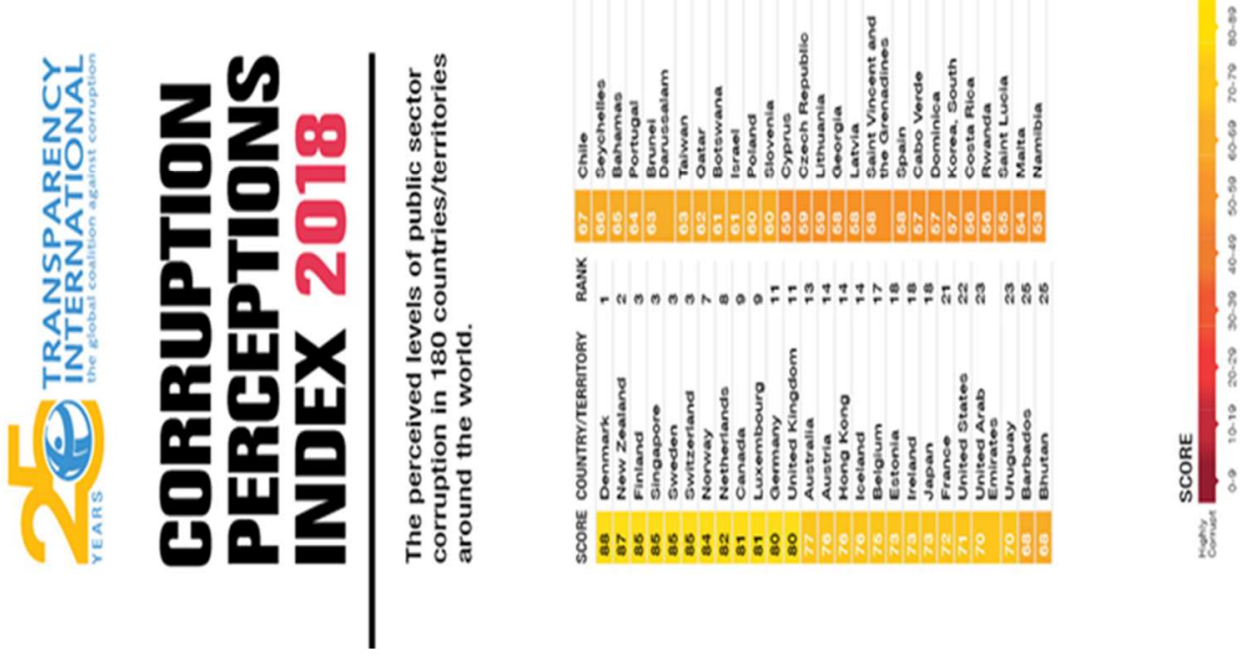
Deste modo, o índice é baseado em como as pessoas veem a corrupção em determinados países, ou seja, se elas, subjetivamente e baseadas em experiências próprias, contadas por terceiros ou divulgadas pela mídia, consideram determinado país mais ou menos corrupto que os demais.

Como segundo ponto de atenção, vale lembrar que a percepção de corrupção abrange apenas a seara pública, não se estendendo à medição da corrupção privada. E como terceiro e último ponto de atenção, vale lembrar que a pesquisa é realizada fora do país avaliado, isto é, para pessoas que não são residentes no país sujeito à medição.

Convém salientar que existem outras pesquisas de âmbito local, como o chamado Barômetro da Corrupção, também realizada pela entidade Transparência Internacional, que mede a corrupção sob a ótica interna, ou seja, como os próprios residentes de um país percebem a corrupção dentro de sua localidade.

Pois bem, como já mencionado, o Brasil ocupa a $105^{a}$ posição no ranking de percepção de corrupção no setor público, divulgado em 2019 pela Transparência Internacional. Isso significa que ele caiu 9 posições no IPC este ano, em comparação ao ano anterior, entre 180 países avaliados. A sua pontuação, pela medição, passou de 37 para 35, sendo o pior resultado desde 2012, quando os dados passaram a ser comparáveis ano a ano. Representa, por conseguinte, a $3^{a}$ queda anual seguida, como pode ser verificado na Figura 4. 


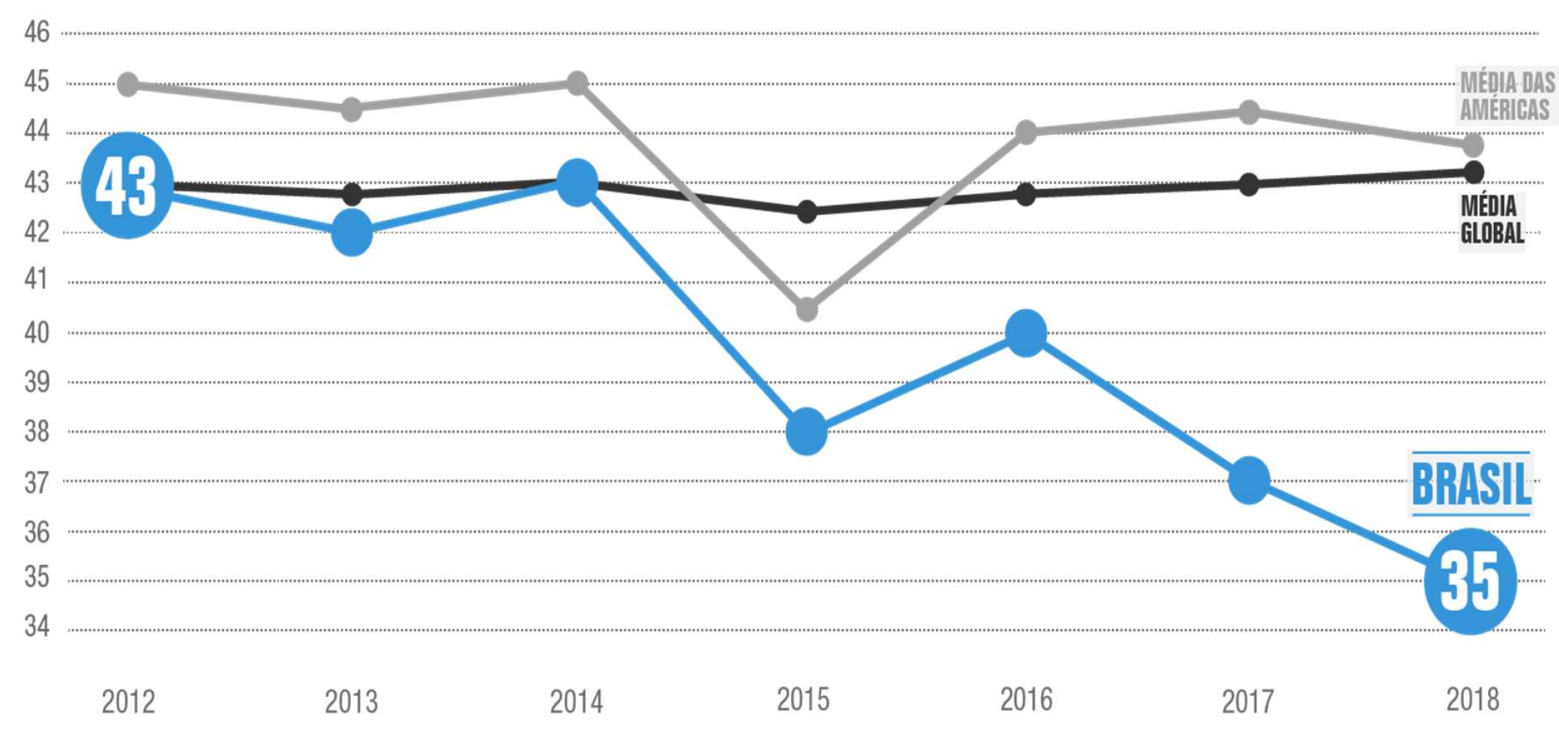

Figura 4 - Pontuação do Brasil no Índice de Percepção da Corrupção Fonte: Transparência Internacional; 2019.

Se focarmos comparativamente na América do Sul, o Brasil se encontra no citado ranking atrás de Chile, Argentina e Uruguai. Quando comparado ao Chile, que é um país referência para políticas de investimento e segue normas internacionais de integridade, parece natural estarmos nessa posição. Ao considerarmos Argentina e Uruguai, todavia, essa posição representa um cenário bastante prejudicial. Isso ocorre pois, mais que o Brasil, a Argentina, por exemplo, possui uma reputação de um país não só inadimplente, mas que também vem há anos passando por governos que não prezam as Convenções Internacionais, principalmente as de âmbito econômico (TRANSPARÊNCIA INTERNACIONAL; 2019).

Quando se menciona posição de inferioridade em relação ao Uruguai, então, o cenário fica ainda pior. Isso ocorre pois o Uruguai é conhecido, no cenário internacional, por possibilitar a constituição de sociedades offshore através de veículos como a Sociedad Anónima Financiera de Inversión - SAFI, que são conhecidas por acobertarem no passado uma gama de negócios ilícitos (MIRA; 2008). Ainda hoje, porém, no ano de 2019, são constituídas sociedades offshore no Uruguai, que funcionam como veículo de blindagem patrimonial ${ }^{9}$.

\footnotetext{
${ }^{9}$ Como pode ser facilmente verificado ao se buscar na rede mundial de computadores escritórios de advocacia que abrem empresas no Uruguai com fins de blindagem patrimonial. Basta acessar, por
} 
Se focarmos comparativamente aos membros do BRICS, sigla que representa os países pertencentes ao bloco de economia emergente, em destaque no cenário globalizado, composto por Brasil, Rússia, Índia, China e África do Sul, o Brasil só está à frente da Rússia (que ocupa a posição 138 no ranking, com 28 pontos somados).

Em relação aos demais países do bloco, fica atrás da Índia (de posição 78 no ranking, com 41 pontos somados) e da China (de posição 87 no ranking, com 39 pontos somados), sem falar na África do Sul, que ocupa a posição de número 73 no citado ranking, com 43 pontos somados, conforme pode ser verificado na Figura 5.

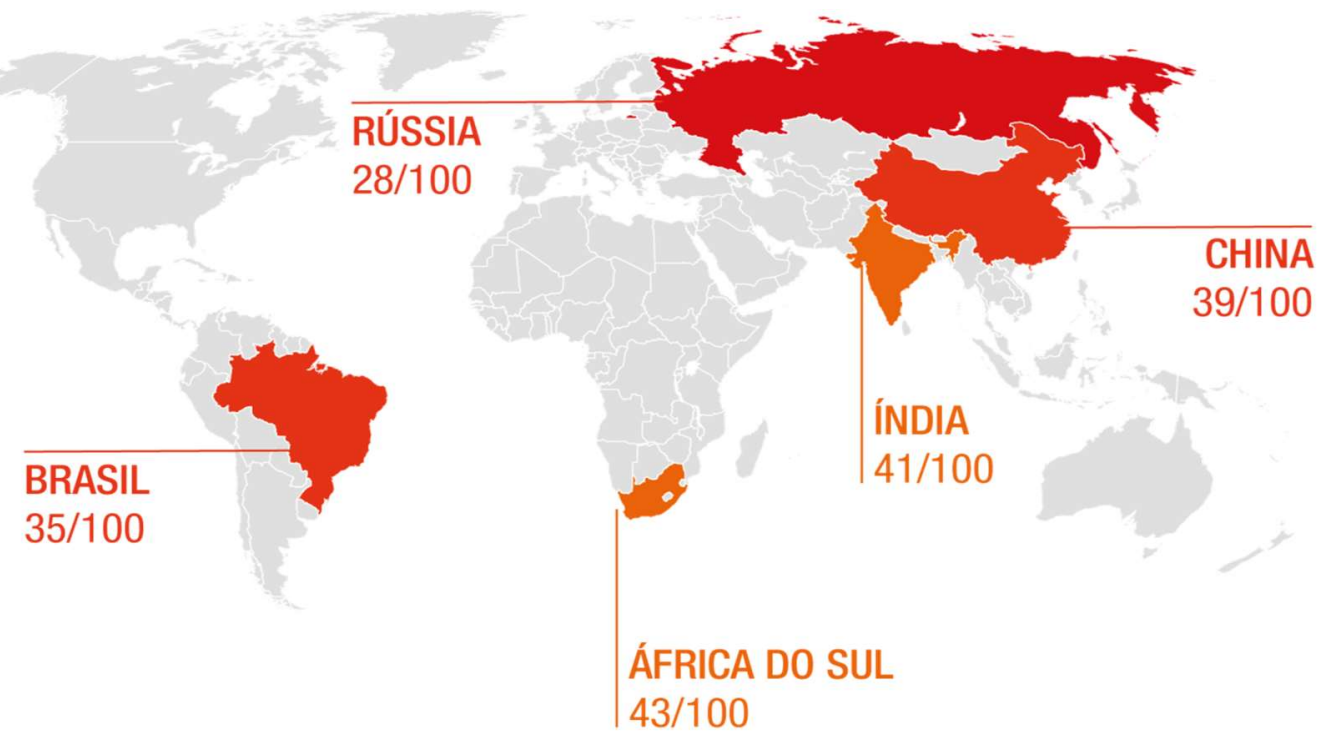

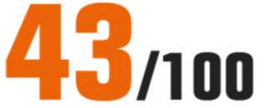

MÉDIA GLOBAL

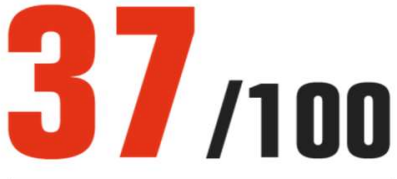

PONTUAÇÃO DOS BRICS

Figura 5 - Pontuação dos BRICS no Índice de Percepção da Corrupção.

Fonte: Transparência Internacional; 2019.

exemplo, a página http://www.Isabogados.com.uy/Iniciar/125/SA-Uruguaia-Off-Shore-e-BeneficiosTributarios/compra-de-sa/. 
Estar à frente da Rússia, em si, não representa qualquer vantagem, já que neste país há uma tradição de corrupção histórica e não existe interesse em produzir esforços reais para mudar essa situação. Estar atrás de China, Índia e África do Sul, todavia, revela-se um problema muito maior, já que nestes países também existe o fomento à corrupção e negligência com a transparência, o que deixa o Brasil em uma situação comprometedora perante a comunidade internacional. $\mathrm{Na}$ China, inclusive, presume-se que a corrupção seja muito maior do que aquela percebida, já que existe um controle robusto dos veículos de comunicação e da divulgação de notícias para o restante do mundo, principalmente aquelas que divulgariam ou poderiam denunciar atos de corrupção (PRAÇA; 2018).

\subsection{Efeitos da Corrupção sobre a Credibilidade}

A corrupção em si, ou mesmo a percepção da corrupção, reflete um cenário extremamente preocupante quando visto em qualquer um de seus aspectos, pois representa uma crise acentuada de credibilidade para qualquer país, interna e externa. Pela perspectiva do lado social, são consideradas as pessoas que têm suas vidas afetadas pela corrupção, através do dinheiro que deixa de ser aplicado em assuntos sociais prioritários, como saúde, educação, segurança e bem-estar social (ROSENBERG; 2016).

Sob o ponto de vista econômico, a corrupção tende a distorcer a alocação eficiente de recursos em uma economia, favorecendo empresas e projetos ineficientes em detrimento de empresas e projetos que seriam mais eficientes. Com isso, desvia-se a economia de seu ponto ótimo de eficiência e maximização de bem-estar. O favorecimento ilícito da empresa ineficiente leva a uma distribuição desigual da renda e prejudica o funcionamento eficiente de uma economia (ROSENBERG; 2016).

De outro lado, sob o ponto de vista dos potenciais investidores, esse quadro ainda é agravado pelas notícias de corrupção, sobre o Brasil, que diariamente são espalhadas ao redor do mundo, afetando todo o sistema econômico, não só pela exposição na mídia internacional, mas principalmente pela oneração da 
classificação de risco de investimento dada ao país, pelas agências de risco estrangeiras ${ }^{10}$, conforme ilustrado na Figura 6.
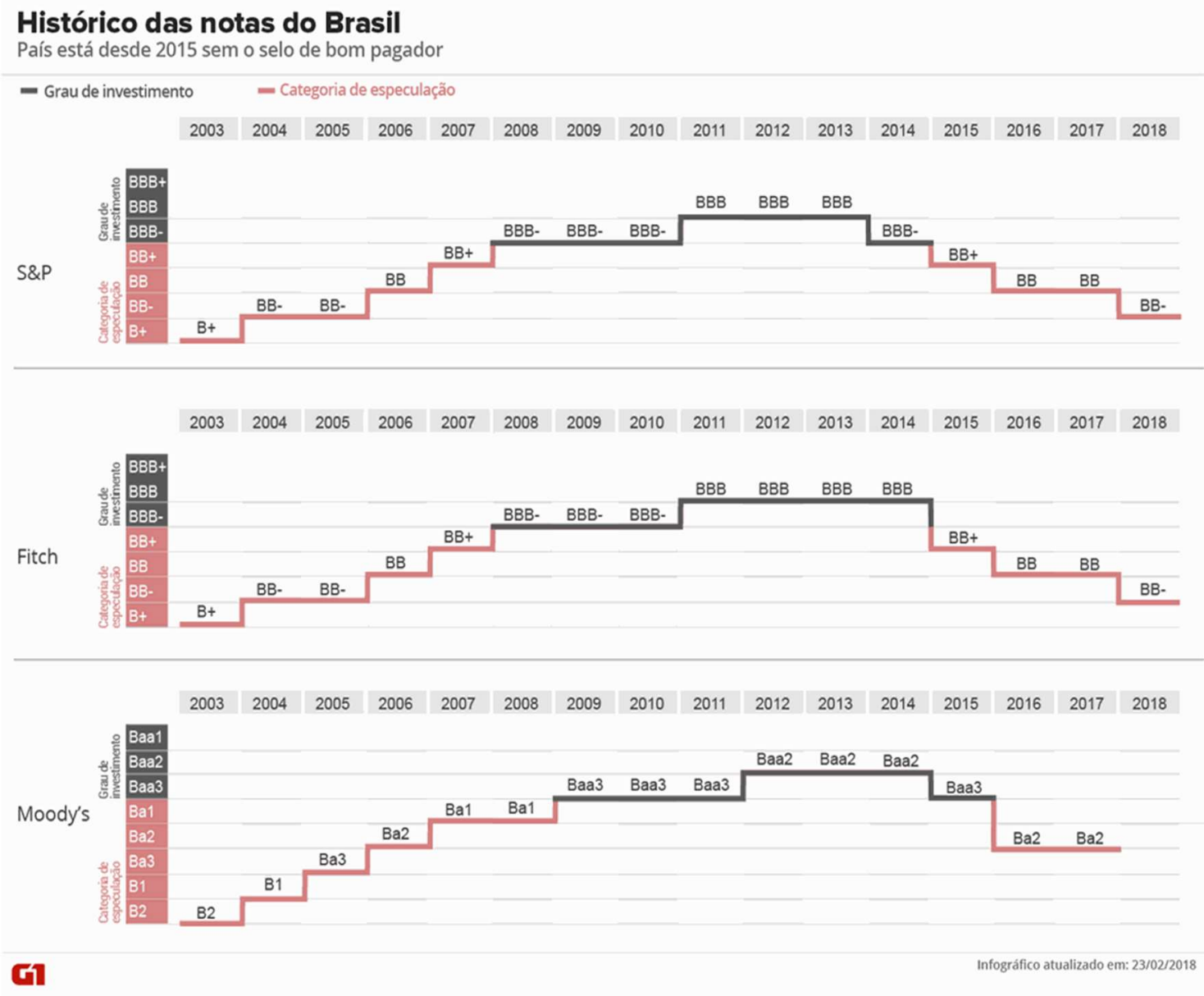

Figura 6 - Corruption Perception Index.

Fonte: Transparência Internacional, 2019.

Neste sentido, passam também a ser considerados, como gastos inerentes a eventuais investimentos no Brasil, todos os custos relacionados a sistemas de prevenção à corrupção, tais como a implementação de controles internos e

\footnotetext{
${ }^{10}$ As agências de rating realizam avaliações sobre países, instituições, empresas, etc. e atribuem notas de risco sobre a capacidade de pagarem as suas dívidas e de retorno de investimento. Ou seja, avaliam se um país ou empresa está em boas ou más condições para pagar o dinheiro pedido na data acordada. Investidores de todo o Mundo usam estas agências de rating para avaliar o risco que têm ao emprestar dinheiro a determinados países ou empresas. Existem há vários anos e foram criadas para fornecer avaliações independentes sobre investimentos. No início, os investidores pagavam para obter esses dados. Em 1975, nos EUA, devido a uma proliferação de agências de ratings - algumas com objetivos menos claros - decidiu-se que apenas a Standard\&Poor's, Moody' s e Fitch poderiam ser utilizadas oficialmente. Disponível na página da web RTP notícias https://www.rtp.pt/noticias/economia/afinal-oque-sao-as-agencias-de-ratingt_n340150.
} 
compliance. Além disso, passa a existir a necessidade de estruturar áreas ligadas ao controle de riscos, auditoria e monitoramento, o que aumenta o custo para investimento em novas empresas.

Fato é que, além de todos os efeitos já mencionados, a crise de credibilidade no país atingiu também a credibilidade de algumas das suas maiores empresas, incluídas aí a Petrobras e a grande maioria das grandes empreiteiras, que perderam milhares de reais em valor de mercado. No caso da Petrobras, que desde sua criação galgou um caminho incomparável ao posto de uma das maiores empresas petrolíferas do mundo, a crise de credibilidade trouxe a essa empresa uma perda de valor de mercado de proporções gigantescas, alcançando montantes superiores a $R \$ 100$ bilhões, com o preço das ações caindo vertiginosamente nas bolsas do Brasil e do mundo (TORRES; 2015).

Como consequência, criou-se uma demanda de mercado para ajuste das empresas aos termos das diversas legislações anticorrupção e consequente implementação de programas de compliance anticorrupção ou de integridade. Esses programas, obviamente, costumam seguir padrões normativos relevantes, sendo fundamentados não somente nas legislações específicas de cada país, mas também nas legislações internacionais e convenções assinadas entre os países do mundo. Referidas normas, que amparam as empresas que desejam implementar programas de compliance das mais diversas áreas, formam um complexo arcabouço regulatório de integridade, cujo alcance obrigacional, seja por vínculo direto ou por área de influência, alcança todo o globo. 


\section{CAPÍTULO 3. LEGISLAÇÃO ANTICORRUPCCÃO}

A legislação anticorrupção, em âmbito geral, abrange as normas de cunho internacional que são propostas por entidades ou organizações supranacionais, como o pacto anticorrupção da Organização das Nações Unidas (ONU), por exemplo; bem como as leis anticorrupção vigentes nos diversos países pelo mundo, como as legislações anticorrupção norte-americana e a brasileira.

Para fins deste trabalho, vamos explanar sobre a legislação anticorrupção abrangendo dois grandes grupos. $\mathrm{O}$ primeiro, incluirá as normas e leis que refletem o cenário internacional, e abrangerá as três principais convenções internacionais anticorrupção, a Convenção Interamericana Contra a Corrupção, da Organização dos Estados Americanos (OEA); a Convenção sobre o Combate da Corrupção de Funcionários Públicos Estrangeiros em Transações Comerciais Internacionais, da Organização para a Cooperação e Desenvolvimento Econômico (OCDE); e a Convenção Anticorrupção da Organização das Nações Unidas (ONU).

Além disso, nesse primeiro bloco serão relacionadas também as duas leis anticorrupção mais influentes do mundo: a lei anticorrupção norte-americana, o Foreign Corrupt Practices Act - (FCPA), e a lei anticorrupção do Reino Unido, o United Kingdom Bribery Act - (UKBA).

O segundo grupo, por sua vez, incluirá as leis que refletem a temática anticorrupção no cenário nacional, subdividindo-as conforme a abrangência de sua responsabilização, ou seja, entre aquelas que responsabilizam as pessoas físicas e aquelas que responsabilizam as pessoas jurídicas brasileiras.

\subsection{Legislação Anticorrupção Internacional}

Embora a legislações anticorrupção tenham começado a ser difundidas nos anos 70 , logo após o caso Watergate, somente após os atentados terroristas de 11 de setembro houve uma mobilização internacional para combate à lavagem de 
dinheiro, muito em função desse dinheiro ser utilizado para fins escusos, como o terrorismo, por exemplo (RICUPERO; 2003).

Essa mobilização ficou mais evidente com o aumento da instituição de leis específicas de prevenção à corrupção por todo o mundo, com a intensificação no combate e na exposição de casos na mídia e com a crescente colaboração entre autoridades internacionais. Isso ocorreu, ainda, porque havia uma especial atenção em relação às empresas que operavam em países com maior sujeição à corrupção, criando as chamadas red flags ou bandeiras de atenção, que eram alertas emitidos à comunidade internacional informando sobre países com alto potencial de práticas de corrupção (ELLIS; 2014).

Deste modo, para regulamentar a integridade e o combate à corrupção em todo mundo, foram surgindo diversas normas internacionais focadas em regulamentar a integridade, iniciando-se pelo FCPA norte-americano, passando pelas diversas convenções internacionais e aprimorando-se com o UKBA britânico. Neste sentido, são consideradas como as normas mais relevantes as convenções instituídas por organizações supranacionais, como a OEA, a OCDE e a ONU; bem como as legislações regulatórias de combate à corrupção norte-americana e do Reino Unido.

Iniciando-se pelas convenções internacionais, como já dito anteriormente, temos nas três convenções da OEA, da OCDE e da ONU, os normativos internacionais anticorrupção mais relevantes. São elas: a Convenção Interamericana Contra a Corrupção, da Organização dos Estados Americanos; a Convenção sobre o Combate da Corrupção de Funcionários Públicos Estrangeiros em Transações Comerciais Internacionais, da Organização para a Cooperação e Desenvolvimento Econômico; e a Convenção Anticorrupção da Organização das Nações Unidas.

Elas são consideradas as mais importantes basicamente pela conjugação de dois fatores: primeiramente, pelo número de nações que expressamente aderiram aos seus termos, chamadas de nações signatárias. Além disso, pelo fato de terem sido promulgadas como lei efetiva na grande maioria dessas 
nações. No Brasil, por exemplo, os Decretos n. ${ }^{\circ}$ s 3.678/0011, 4.410/02 ${ }^{12}$ e $5.687 / 06^{13}$ promulgam, respectivamente, as convenções internacionais anticorrupção da OECD, da OEA e da ONU.

A Convenção Interamericana Contra a Corrupção, da Organização dos Estados Americanos, foi instituída no ano de 1996 e visa promover e fortalecer o desenvolvimento de mecanismos para prevenir, detectar, punir e erradicar a corrupção, bem como adotar ações que assegurem a cooperação entre os países signatários.

Para os fins estabelecidos nessa convenção, devem ser adotadas medidas e mecanismos para, basicamente, impedir o suborno de funcionários públicos nacionais e estrangeiros; e garantir que as empresas mantenham registros que reflitam com detalhe e exatidão a aquisição e alienação de ativos e controles internos que permitam aos funcionários da empresa detectarem a ocorrência de atos de corrupção.

O Brasil é nação signatária desde o ano de 2002, e comprometeu-se a adotar medidas preventivas, em seus próprios sistemas institucionais, que contribuiriam para a eficácia da Convenção, dentre as quais o estímulo à participação da sociedade civil e de organizações não governamentais na prevenção à corrupção. Foi a primeira convenção anticorrupção a ser formatada no cenário internacional e representou um esforço pessoal dos Estados Unidos de América (EUA), que já vinha articulando ações no sentido de formalizar uma norma

\footnotetext{
11 Promulga a Convenção sobre o Combate da Corrupção de Funcionários Públicos Estrangeiros em Transações Comerciais Internacionais, concluída em Paris, em 17 de dezembro de 1997. Art. 1o A Convenção sobre o Combate da Corrupção de Funcionários Públicos Estrangeiros em Transações Comerciais Internacionais, concluída em Paris, em 17 de dezembro de 1997, apensa por cópia a este Decreto, deverá ser executada e cumprida tão inteiramente como nela se contém.

12 Promulga a Convenção Interamericana contra a Corrupção, de 29 de março de 1996, com reserva para o art. XI, parágrafo 10, inciso "c". Art. 10 A Convenção Interamericana contra a Corrupção, adotada em Caracas, em 29 de março de 1996, apensa por cópia ao presente Decreto, será executada e cumprida tão inteiramente como nela se contém, com reserva para o art. XI, parágrafo 1으, inciso "c".

13 Promulga a Convenção das Nações Unidas contra a Corrupção, adotada pela Assembleia-Geral das Nações Unidas em 31 de outubro de 2003 e assinada pelo Brasil em 9 de dezembro de 2003. Art. 10 A Convenção das Nações Unidas contra a Corrupção, adotada pela Assembleia-Geral das Nações Unidas em 31 de outubro de 2003 e assinada pelo Brasil em 9 de dezembro de 2003, apensa por cópia ao presente Decreto, será executada e cumprida tão inteiramente como nela se contém.
} 
anticorrupção de alcance supranacional. Possui, todavia, um viés mais regional, já que vincula apenas os países pertencentes à OEA.

A Convenção sobre o Combate da Corrupção de Funcionários Públicos Estrangeiros em Transações Comerciais Internacionais, da Organização para a Cooperação e Desenvolvimento Econômico, por sua vez, foi instituída no ano de 1999 e define as obrigações de combate à corrupção para governos, empresas, contadores públicos, advogados e sociedade civil das nações signatárias do tratado.

Para os fins estabelecidos nessa convenção, devem ser adotadas medidas e mecanismos para, basicamente, estabelecer responsabilidades de pessoas jurídicas pela corrupção de funcionário público, de acordo com seus princípios jurídicos. Além disso, visa proibir práticas contábeis inadequadas, com o propósito de corromper ou ocultar corrupção, por companhias sujeitas a leis e regulamentos sobre manutenção de livros e registros contábeis, divulgação de declarações financeiras e sistemas de contabilidade e auditoria.

O Brasil é nação signatária desde o ano de 2000, e comprometeu-se em buscar a implementação de medidas de ordem jurídica e administrativa que viessem a permitir o alcance dos objetivos previstos na referida convenção. Essa convenção, de forma diferente da convecção da OEA, já possui um viés mais voltado para o comércio entre as nações e, principalmente, para a responsabilização de pessoas físicas que pudessem praticar atos de corrupção nas ações comerciais de âmbito internacional.

Finalmente, a Convenção da ONU, também conhecida como Convenção de Mérida, foi instituída no ano de 2003, sendo que o Brasil é país signatário desde o ano de 2006. É, sem dúvida, o mais extenso texto internacional juridicamente vinculante, obrigando os países signatários a cumprir os seus dispositivos, respeitados a soberania e direito interno de cada país.

A Convenção de Mérida, estabelece, em seu art. 12, que os Estados-partes deverão adotar medidas para prevenir a corrupção e melhorar as normas 
contábeis e de auditoria no setor privado, assim como prever sanções civis, administrativas ou penais eficazes, proporcionadas e dissuasivas em caso de não cumprimento destas medidas.

Além disso, os Estados-partes deverão promover a formulação de normas e procedimentos com o objetivo de salvaguardar a integridade das entidades privadas, incluídos os códigos de conduta, assim como para a promoção do uso de boas práticas comerciais entre as empresas e as relações contratuais destas com o Estado (VERÍSSIMO; 2017, p.13).

Para os fins estabelecidos nessa convenção, deveriam ser adotadas medidas e mecanismos para, basicamente, exigir que empresas privadas disponham de suficientes controles internos para ajudar a prevenir e detectar os atos de corrupção e para que as contas e práticas contábeis dessas empresas estejam sujeitas a procedimentos apropriados de auditoria e certificação.

Além disso, visa estabelecer a cooperação entre os organismos de investigação e as entidades do setor privado em questões relativas à prática dos delitos qualificados na convenção. Por ter um viés mais global e menos regionalizado, possui maior notoriedade no cenário internacional que as demais convenções. É também a mais conhecida e mais citada norma internacional de integridade.

Ressalte-se que entre a Convenção da OCDE e a Convenção de Mérida, mais precisamente no ano de 2000 , houve um importante reforço internacional no combate à corrupção, que foi a instituição do Pacto Global da Organização das Nações Unidas (ONU). O Pacto Global foi uma iniciativa desenvolvida pelo exsecretário-geral da ONU, Kofi Annan, com o objetivo de mobilizar a comunidade empresarial internacional para a adoção, em suas práticas de negócios, de valores fundamentais e internacionalmente aceitos nas áreas de direitos humanos, relações de trabalho, meio ambiente e combate à corrupção refletidos em 10 princípios (NAÇÕES UNIDAS BRASIL, 2019).

Uma vez realizada uma explanação sobre as mais importantes convenções internacionais de integridade, faz-se necessário discorrer sobre as duas mais 
relevantes legislações estrangeiras de combate internacional à corrupção: a lei norte-americana conhecida como FCPA e a lei britânica conhecida como UKBA.

A Foreing Corrupt Practices Act - FCPA, é a mais importante e influente legislação anticorrupção estrangeira no mundo (ESTADO DE SÃO PAULO; 2016). Trata-se de uma lei norte-americana sancionada em 1977, em resposta ao escândalo Watergate, quando o $\mathrm{FBI}$ e a agência reguladora de valores mobiliários, a Securities Exchange Commission (SEC), descobriram uma série de pagamentos ilegais a oficiais, políticos e partidos políticos em outros países, conforme detalhes já mencionados anteriormente neste trabalho.

Alterada em 1998, a FCPA passou a ter efeitos para empresas sediadas em países estrangeiros que realizam operações nos EUA, inclusive operações de capitais. Alcança, portanto, qualquer cidadão americano ou entidade constituída sob as leis dos EUA, incluindo empresas estrangeiras listadas nas bolsas de valores norte-americanas e seus representantes, além de multinacionais com filiais nos EUA e seus representantes.

Exige basicamente a adoção de sistemas contábeis que efetivamente reflitam as transações e as disposições dos ativos do emissor. Exige ainda a fixação de sistema de controles internos capaz de prevenir atividades ilegais e garantir que todo pagamento realizado seja de conhecimento dos administradores.

Além disso, sob a égide da FCPA, uma empresa não pode dar, oferecer, prometer ou autorizar que se dê qualquer coisa de valor a funcionário de governo estrangeiro, quer diretamente ou por meio de um intermediário, a fim de influenciar a ação do funcionário para obter vantagens impróprias. Regra, portanto, a corrupção praticada fora das fronteiras dos EUA (UNITED STATES DEPARTMENT OF JUSTICE; 2018).

A fiscalização em relação à conformidade à FCPA é realizada pela SEC e pelo Department of Justice (DOJ) norte-americano. Ambas as entidades trabalham em parceria combinando investigação e aplicação de penalidades. A responsabilidade pela aplicação das penalidades administrativas fica a cargo da 
SEC, enquanto as ações judiciais e acordos jurídicos fica a cargo do DOJ. Na praxe cotidiana, ambos os órgãos são bastante atuantes em relação à fiscalização realizada perante as empresas sujeitas à FCPA.

As fiscalizações são normalmente efetuadas através da classificação de risco das empresas, levando-se em conta os critérios arbitrados pela própria SEC e pelo DOJ. Neste sentido, de acordo com as características de cada empresa, esses órgãos lhes atribuem as chamadas red flags ou bandeiras de atenção, cujo objetivo é identificá-las como corporações sujeitas a um grau maior de risco, com referência à prática de atos de corrupção (ELLIS; 2014).

São critérios definidores de risco para a SEC e o DOJ, entre diversos exemplos que podem ser citados, o país de atuação da empresa, que será mais fiscalizada caso esse país possua um alto índice de corrupção; o volume de transações financeiras internacionais realizadas pela empresa, que deverá corresponder ao volume de negócios focado na sua atividade econômica (sob risco de haver desvio de finalidade); a ocorrência de superfaturamentos ou percentuais de comissão elevados, o que daria indícios de utilização de verba para fins ilícitos; e a tipificação de ativos e funcionários insuficientes para atender aos contratos declarados pela empresa, o que poderia indicar declaração falsa de negócios (UNITED STATES DEPARTMENT OF JUSTICE; 2018).

Além disso, ensejaria também maior risco, a constatação do fornecimento de informações relevantes incompletas, como a descrição cadastral insuficiente de acionistas de parceiros, por exemplo, o que caracterizaria não-conformidade aos termos da legislação. Outro ponto de atenção seria a hipótese de verificação da existência de relações pessoais, profissionais ou familiares com agente público, já que isso poderia ensejar a prática de atos de corrupção. Mais um ponto seria representado pelo repasse frequente de contratos sob a forma de quarteirização, prática essa que, apesar de ser muito comum em países em desenvolvimento, normalmente dá margem a negociações ilícitas (UNITED STATES DEPARTMENT OF JUSTICE; 2018). 
E finalmente, como último ponto, poderia ser aventada a presença de elevados aditamentos de contratos, os chamados "claims", que se caracterizam por configurarem pedidos de aumento dos valores originalmente avençados entre as partes, na realização de um determinado serviço. Esses pedidos, normalmente realizados em empreitadas de infraestrutura (como por exemplo na realização de grandes obras para o Poder Público), quando realizados em excesso, normalmente indicam a ocorrência de atos lesivos contra a administração pública, o que justifica o redobramento da atenção ${ }^{14}$.

Na prática, esse comportamento da SEC e do DOJ tem causado nas empresas uma tendência de autorregulação bastante latente. Sociedades empresariais sujeitas à FCPA têm tomado ações, voluntariamente, para evitar a nãoconformidade aos termos da norma. São ações de autorregulação praticadas pelas empresas, por exemplo, a exigência, a parceiros, quanto ao fornecimento de informações acerca de suas ações para conformidade à FCPA; a apresentação de informações acerca das próprias ações de conformidade à FCPA em relatórios ao mercado e publicação de fatos relevantes; e a realização de auto delação, quando identificado algum tipo de não-conformidade.

São também ações de autorregulação usualmente praticadas a condução de investigações internas, quando há suspeitas de não-conformidade; a cooperação contínua com as autoridades reguladoras nas fiscalizações e investigações; e o afastamento de colaboradores e parceiros em investigação ou ainda que estejam comprovadamente envolvidos em atos ilícitos ou de nãoconformidade (UNITED STATES DEPARTMENT OF JUSTICE; 2018).

É importante ressaltar que o descumprimento aos ditames da FCPA traz, às empresas infringentes, penalidades bastante significativas, tanto de âmbito cível como criminal, contemplando tanto a pessoa física quanto a pessoa jurídica envolvida (PWC; 2013). Para as pessoas jurídicas, as penalidades que

\footnotetext{
${ }^{14}$ Como pode ser constatado, por exemplo, na própria Petrobras, onde o Tribunal de Contas da União apontou que obras investigadas na Operação Lava Jato tiveram aditivos bilionários que chegaram a quintuplicar os valores dos contratos. Conforme disponível na página http://g1.globo.com/politica/operacao-lava-jato/noticia/2015/04/tcu-aponta-excesso-de-aditivos-emcontratos-investigados-na-lava-jato.html
} 
normalmente são aplicadas envolvem multas pecuniárias altas, a divulgação ao mercado de prática de atos de não-conformidade (o que causa um alto grau de dano reputacional à empresa), e a aplicação de sanções administrativas, como o impedimento em participar de certames públicos, entre outros.

Em relação à pessoa física, as penalidades aplicadas são concentradas na aplicação de multas, que diferentemente de outros países, como o próprio Brasil, não podem ser pagas pela empresa. Além disso, pune-se também com pena de prisão e divulgação ao mercado da prática de atos ilícitos, alcançando também a seara reputacional, assim como acontece com as pessoas jurídicas (PWC; 2013). Para tanto, o DOJ está legitimado a ingressar com ações judiciais para imputação de responsabilidade e cobrança de eventuais valores oriundos de condenações, perante a corte de justiça norte-americana.

Segundo Carla Veríssimo (2017; p. 160), em função dos enormes custos monetários e danos à imagem resultantes de uma ação judicial, a maioria dos casos de violação à FCPA são resolvidos administrativamente, através da avença dos chamados Plea Bargaining Processs - PBPs ou acordos de culpa ${ }^{15}$, onde as empresas negociam e aceitam uma combinação de restituição, sanções monetárias e a adoção de medidas estruturais e de governança corporativa.

Às vezes, no entanto, quando não são encontradas provas tão contundentes da culpabilidade das empresas, o DOJ opta por fechar os chamados Non Prosecution Agreements - NPAs ou acordos de não persecução, onde os diversos casos de eventual violação à FCPA são resolvidos pela avença de um acordo sem a assunção de culpa (ALEXANDER; 2015).

Quando, todavia, já existe uma ação judicial ingressada, ainda assim as partes podem optar por fazer um acordo e cessar a sangria de gastos, através dos

\footnotetext{
${ }^{15}$ Os Plea Bargaining Process, na lei, representam a prática de negociar um acordo entre a acusação e a defesa por meio do qual o réu se declara culpado de uma ofensa menor ou (no caso de múltiplas ofensas) a um ou mais delitos acusados, em troca de sentença mais leniente, recomendações, uma sentença específica ou o cancelamento de outras acusações. Os defensores da negociação argumentam que aceleram os processos judiciais e garantem uma condenação, enquanto os opositores acreditam que isso impede que a justiça seja cumprida. A grande maioria dos casos criminais nos Estados Unidos envolve alguma forma de barganha.
} 
Deferred Prosecution Agreements - DPAs, sendo que estes podem ter ou não a assunção de culpa, dependendo do acordo entre as partes (VERÍSSIMO; 2017).

No Brasil, a FCPA tem, sob a égide de seus ditames, o alcance adicional sobre quaisquer empresas brasileiras que possuam negócios nos EUA, tenham subsidiárias naquele país ou, ainda, que sejam listadas nas bolsas de valores norte-americanas. Além disso, atinge quaisquer representantes brasileiros de empresas americanas e, ainda empresas americanas controladoras de subsidiárias brasileiras, que se tornam responsáveis pelos atos dessas empresas.

A United Kingdom Bribery Act - UKBA, de outro lado, é a lei anticorrupção britânica, criada em 2010 e sancionada em 2011. A Lei descreve quatro crimes principais: o crime de corrupção ativa, caracterizado pela ação de oferecer, prometer ou dar propina; o crime de corrupção passiva, caracterizado pela ação de solicitar, concordar em receber ou aceitar propina; o crime de suborno de um funcionário público estrangeiro; e a contravenção corporativa de falha na prevenção de suborno, o chamado "fail to prevent bribery" (UNITED KINGDOM GOVERNMENT; 2018).

No caso da falha na prevenção de suborno, cuja responsabilidade é objetiva e é gerada por uma pessoa agindo para ou em nome da organização que paga o suborno. A lei penaliza, portanto, a corrupção ativa e passiva de sujeitos públicos ou privados; a corrupção de funcionários públicos nacionais e estrangeiros; e as falhas organizacionais para prevenção da corrupção (UNITED KINGDOM GOVERNMENT; 2018).

Comparativamente à FCPA, a UKBA possui uma maior abrangência do que aquela lei, pois, além de penalizar a corrupção em âmbito público, também penaliza os atos de "corrupção comercial" entre particulares, em âmbito privado (PWC; 2013). Neste diapasão, a UKBA veda o oferecimento de quaisquer vantagens a uma pessoa com o intuito de induzi-la, recompensá-la ou de qualquer forma a influenciar a desempenhar de forma imprópria uma função ou atividade. 
A UKBA pune, portanto, aquele que solicita, concorda, recebe ou aceita vantagens. A competência para apuração e punição de eventuais nãoconformidades à UKBA pertence ao órgão público conhecido por Serious Fraud Office $(S F O)^{16}$, que foca na apuração de casos de violação atinentes à corrupção e tem não só função fiscalizadora, mas também punitiva (UNITED KINGDOM GOVERNMENT; 2018).

A norma UKBA traz, em seu bojo, basicamente seis princípios básicos. 0 primeiro, que seria a "proporcionalização" de procedimentos, reflete a diretriz de que os procedimentos de uma organização comercial, para evitar suborno por parte de pessoas associadas a ela, devem ser proporcionais aos riscos de suborno que ela enfrenta e à natureza, escala e complexidade, das atividades da referida organização comercial (UNITED KINGDOM GOVERNMENT; 2018). Eles também devem ser claros, práticos, acessíveis e efetivamente implantados e aplicados.

O segundo, traz a diretriz de que o sucesso ou fracasso derradeiros em um programa anticorrupção dependerá da cultura da organização e do compromisso do alto escalão em implementá-lo e cumpri-lo. Por esse princípio, as pessoas acreditam que o comportamento ético importa para a maneira como elas são avaliadas e recompensadas, o que dependeria da intervenção da alta cúpula da empresa.

O terceiro, por sua vez, ressalta a importância da realização das avaliações de risco. Segundo ele, a avaliação de quais riscos existem pode ajudar a administrálos de maneira eficaz. E uma vez concluída essa avaliação, a organização estará em uma posição muito melhor para decidir quais medidas precisam ser tomadas.

O quarto princípio determina a importância da realização de procedimentos de auditoria de due diligence nas empresas fornecedoras de produtos ou serviços (referidos como "pessoas associadas") na medida em que as empresas estão

\footnotetext{
${ }^{16}$ O Serious Fraud Office investiga e processa fraudes sérias ou complexas, suborno e corrupção.
} 
expostas à responsabilidade indireta pelas ações de terceiros que venham a pagar subornos de qualquer tipo ao mesmo tempo em que fazem algo em seu nome. Uma pessoa associada é definida como um indivíduo ou uma entidade incorporada ou não incorporada que "realiza serviços" para a organização ou em seu nome.

O quinto princípio diz respeito à necessidade de haver constante comunicação, inclusive treinamento, sobre o teor da UKBA a todos os funcionários da empresa. A lei considera que um dos fundamentos vitais para qualquer estrutura anticorrupção é a comunicação eficaz do código de ética ou conduta, dos valores principais da organização e de suas políticas de apoio. Considera-se, ainda, que para o treinamento ser eficaz, ele deve ser regular em vez de feito uma única vez, e a participação e o retorno dos treinados devem ser monitorados e avaliados constantemente.

O sexto e último princípio diz respeito à necessidade de monitoramento e revisão constantes das normas trazidas pela UKBA. Para este fim, o monitoramento e revisão podem ser realizados de duas maneiras: em relação ao monitoramento das transações e relacionamentos existentes, deve ser realizada uma auditoria interna ou procedimento semelhante, enquanto em relação ao monitoramento das informações atuais sobre o que está acontecendo na empresa, deve ser realizado um processo de avaliação de risco.

São penalidades aplicadas pela não-conformidade aos ditames da norma UKBA: Em relação às pessoas jurídicas, a aplicação de multa pecuniária em valor ilimitado. Em relação às pessoas físicas, a aplicação de multa pecuniária em valor ilimitado e/ou a condenação a até 10 anos de prisão. Especificamente para os diretores das empresas, a destituição do cargo e a proibição de atuar como diretor por até 15 anos.

Para contratantes Públicos, uma possível exclusão de contratos públicos. Além disso, prevê a divulgação, na mídia, de que a empresa foi multada e está sendo processada por atos contrários à norma UKBA, o que gera danos reputacionais e à imagem bastante graves (UNITED KINGDOM GOVERNMENT; 2018). 


\subsection{Legislação Anticorrupção Brasileira}

Como já mencionado, as leis que refletem a temática anticorrupção no cenário nacional, podem basicamente ser divididas entre aquelas que responsabilizam as pessoas físicas e aquelas que responsabilizam as pessoas jurídicas brasileiras. Fazem parte do primeiro grupo as leis que responsabilizam, pela prática de atos de corrupção, segmentos específicos da sociedade brasileira, como os administradores de instituições financeiras, os funcionários públicos, os contribuintes de tributos e impostos e as pessoas físicas em geral.

Fazem parte do segundo grupo as leis que responsabilizam as pessoas jurídicas, sejam elas as empresas privadas, associações e instituições, ou mesmo as empresas públicas. Cumpre esclarecer que o grande divisor de águas para fins de responsabilização é, sem dúvida, a chamada Lei Anticorrupção Brasileira (LAB), que demarcou o início da responsabilização das pessoas jurídicas no Brasil, conforme veremos mais adiante (MANDEL; 2014).

Neste diapasão, é importante registrar que não havia histórico, no Brasil, de uma legislação anticorrupção coordenada, e sim apenas legislações esparsas e de difícil aplicabilidade prática. Podem ser resumidos os esforços legislativos anticorrupção, até a promulgação da Lei Anticorrupção Brasileira, da seguinte forma:

Em primeiro lugar, pela promulgação dos Decretos n. ${ }^{\circ}$ s 3.678/00, 4.410/02 e $5.687 / 06$, que dão validade jurídica, respectivamente, às convenções internacionais anticorrupção da OECD, da OEA e da ONU, sendo que esta última, em razão de alteração no texto constitucional, está equiparada à emenda constitucional, conforme estabelece o art. $5^{\circ}, \S^{\circ}$ da Constituição Federal. 
Além disso, a própria Constituição Federal do Brasil ${ }^{17}$ estabelece a legalidade como princípio obrigatório da administração pública e necessidade de observância da lei por todas as pessoas. Determina, também, a responsabilidade das empresas quanto aos atos praticados contra a ordem econômica e financeira e contra a economia popular, dando a base legal necessária para criação de toda a legislação de integridade que viria a ser constituída posteriormente.

O passo seguinte foi dado pela promulgação da lei n. ${ }^{0} 7.492 / 86^{18}$, também conhecida como Lei do Colarinho Branco, que define os crimes contra o sistema financeiro nacional. Essa lei foi criada exatamente para alcançar administradores e diretores de instituições financeiras que praticassem atos de corrupção.

Na sequência, foi promulgada a lei n. ${ }^{\circ} 8.137 / 90^{19}$, que define os crimes contra a ordem tributária, econômica e contra as relações de consumo. Nesse caso, a responsabilização foi trazida pelo artigo $3^{\circ}$ da referida lei, que diz constituir crime funcional contra a ordem tributária exigir, solicitar ou receber, para si ou para outrem, direta ou indiretamente, ainda que fora da função ou antes de iniciar seu exercício, mas em razão dela, vantagem indevida; ou aceitar promessa de tal vantagem, para deixar de lançar ou cobrar tributo ou contribuição social, ou cobrá-los parcialmente.

\footnotetext{
${ }^{17}$ De acordo com o art. 5o, inciso II, da Constituição Federal, "ninguém será obrigado a fazer ou deixar de fazer alguma coisa senão em virtude de lei". Por isso o princípio da legalidade é verdadeiramente uma garantia dada pela Constituição Federal a todo e qualquer particular.

${ }^{18}$ Define os crimes contra o sistema financeiro nacional, e dá outras providências.

${ }^{19} \mathrm{Art.} 3^{\circ}$ Constitui crime funcional contra a ordem tributária, além dos previstos no Decreto-Lei $\mathrm{n}^{\circ} 2.848$, de 7 de dezembro de 1940 - Código Penal (Título XI, Capítulo I): I - extraviar livro oficial, processo fiscal ou qualquer documento, de que tenha a guarda em razão da função; sonegá-lo, ou inutilizá-lo, total ou parcialmente, acarretando pagamento indevido ou inexato de tributo ou contribuição social; II - exigir, solicitar ou receber, para si ou para outrem, direta ou indiretamente, ainda que fora da função ou antes de iniciar seu exercício, mas em razão dela, vantagem indevida; ou aceitar promessa de tal vantagem, para deixar de lançar ou cobrar tributo ou contribuição social, ou cobrá-los parcialmente. Pena - reclusão, de 3 (três) a 8 (oito) anos, e multa.III - patrocinar, direta ou indiretamente, interesse privado perante a administração fazendária, valendo-se da qualidade de funcionário público. Pena - reclusão, de 1 (um) a 4 (quatro) anos, e multa.
} 
A lei n. ${ }^{\circ} 8.429 / 92^{20}$, por sua vez, também conhecida como a Lei da Improbidade Administrativa, trouxe um avanço muito importante ao definir que a obtenção de qualquer vantagem pecuniária indevida em razão de uma posição, mandato, função, emprego ou atividade públicos é uma improbidade administrativa, penalizando especificamente o funcionário público.

Outro avanço bastante comemorado veio com a lei $n .^{\circ} 8.666 / 93^{21}$, a chamada Lei das Licitações, que prevê expressamente, em seu texto, que o processo de contratos públicos deve ser anulado em caso de ilegalidade, que compreende a ocorrência de corrupção, inclusive contratos de concessão de serviços públicos.

$E$, por fim, temos a lei n. ${ }^{\circ} 9.613 / 98^{22}$, que estabelece mecanismos de controle a serem realizados por empresas que tenham, em caráter permanente ou eventual, como atividade principal ou acessória, cumulativamente ou não, a captação, intermediação e aplicação de recursos financeiros de terceiros, em moeda nacional ou estrangeira, tutelando, portanto, os participantes de fundos de investimentos contra atos de corrupção.

Note-se que, até o momento, buscou-se trazer uma compilação das normas penais de responsabilização das pessoas físicas considerando suas respectivas atuações em diversos nichos econômicos. Neste sentido, tem-se a responsabilização de administradores de instituições financeiras, de agentes públicos em atos de crime contra a ordem tributária e de improbidade administrativa, bem como pessoas envolvidas em processos de licitação e de gestão de fundos de investimento.

A penalização geral às pessoas físicas, pela prática de atos de corrupção, seja em âmbito passivo ou ativo, no entanto, é tipificada e prevista expressamente na

\footnotetext{
${ }^{20}$ Dispõe sobre as sanções aplicáveis aos agentes públicos nos casos de enriquecimento ilícito no exercício de mandato, cargo, emprego ou função na administração pública direta, indireta ou fundacional e dá outras providências.

${ }^{21}$ Regulamenta o art. 37, inciso XXI, da Constituição Federal, institui normas para licitações e contratos da Administração Pública e dá outras providências.

22 Dispõe sobre os crimes de "lavagem" ou ocultação de bens, direitos e valores; a prevenção da utilização do sistema financeiro para os ilícitos previstos nesta Lei; cria o Conselho de Controle de Atividades Financeiras - COAF, e dá outras providências.
} 
maior norma de criminalização brasileira, o Código Penal. Deste modo, embora seja uma legislação que também responsabilize e penalize pessoas físicas, o Decreto-Lei n. ${ }^{\circ} 2.848$, de 7 de dezembro de 1940, popularmente conhecido como Código Penal Brasileiro, tem que ser tratado como um ponto à parte no presente trabalho.

Isso ocorre pois ele tem o condão de tipificar as principais condutas criminosas das pessoas físicas, sob a égide da legislação brasileira, independente de segmento econômico ou viés de mercado a ser tutelado. E assim, nesse espírito, foram acrescentados os crimes de corrupção nele previstos, que ao longo dos anos sofreram diversas modificações e culminaram nos atuais artigos 316,317 e 333 do referido diploma legal.

Referidos artigos preveem, respectivamente, os crimes de corrupção passiva, concussão e corrupção ativa, respectivamente. Inicialmente faz-se importante verificar os crimes de corrupção mais comuns, cometidos por pessoas físicas, e que estão previstos nos artigos 333 e 317 do Código Penal Brasileiro, ou seja, os crimes de corrupção ativa e de corrupção passiva.

Reza o artigo 333, do citado diploma legal, que comete crime de corrupção ativa aquele que oferecer ou prometer vantagem indevida a funcionário público, para determiná-lo a praticar, omitir ou retardar ato de ofício. Este é o típico caso de corrupção cometido por qualquer pessoa física, e prevê pena de 2 (dois) a 12 (doze) anos de reclusão para quem for condenado pela sua prática.

Deve ser ressaltado o quão baixa é a pena, considerando eventuais bons antecedentes e primariedade do réu, o que pode rápida e sumariamente reduzir sua pena em um terço e permitir que em muito pouco tempo sua prisão seja convolada em regime aberto ou mesmo prisão domiciliar, e muitas vezes faz compensar a prática de crimes de corrupção.

O artigo 317, por sua vez, reflete o crime de corrupção passiva, tipificado pela conduta de solicitar ou receber, para si ou para outrem, direta ou indiretamente, ainda que fora da função ou antes de assumi-la, mas em razão dela, vantagem 
indevida, ou aceitar promessa de tal vantagem. Este crime só pode ser cometido por funcionário público ou equiparado e prevê, da mesma forma, uma pena de 2 (dois) a 12 (doze) anos de reclusão para quem for condenado pela sua prática.

É interessante notar que o texto da lei tenta prever todas as hipóteses em que poderia ocorrer o crime, como, por exemplo, o fato não só de solicitar a vantagem, mas também simplesmente recebê-la, ou então o fato de poder pedila não para si mesmo e diretamente, mas para outrem, e também de forma indireta.

Mais que isso, o delito pode ser tipificado, inclusive, caso o funcionário público ainda não tenha sido empossado no cargo ou esteja suspenso. Verifica-se que o legislador tentou trazer, portanto, toda a gama possível de ações que poderiam ser praticadas pelo agente criminoso, mitigando o risco de que houvesse qualquer possibilidade de não caracterização do crime.

Finalmente, o artigo 316 do Código Penal Brasileiro tipifica o chamado crime de concussão, prevendo cometer o referido delito aquele que exigir, para si ou para outrem, direta ou indiretamente, ainda que fora da função ou antes de assumila, mas em razão dela, vantagem indevida. Com relação a este crime, cabem ser realizadas algumas ressalvas.

Preliminarmente, o fato de que o crime de concussão tem texto idêntico ao crime de corrupção passiva, exceto pelo fato de que, diferentemente deste crime, onde o agente criminoso solicita a vantagem indevida, no crime de concussão o agente exige a vantagem.

Esta é uma sutil, porém problemática diferença entre os delitos apontados. Em primeiro lugar em razão da pena a ser aplicada pelas suas respectivas práticas: enquanto na corrupção passiva a pena é de 2 (dois) anos a 12 (doze) anos, na concussão a pena prevista é de 2 (dois) anos a 8 (oito) anos.

Mas como explicar essa diferença, uma vez que o crime de concussão é mais grave que o crime de corrupção passiva? A resposta pode ser encontrada na Lei 
10.763/2003 que aumentou o limite máximo em abstrato dos delitos de corrupção ativa e corrupção passiva, mas não se pronunciou sobre o crime de concussão (TALON; 2017).

Como resultado, temos um crime mais grave punido mais brandamente, o que gera argumento para eventuais pedidos de redução de pena nos crimes de corrupção passiva, causando uma situação jurídica inusitada. Além disso, e em segundo lugar, porque se levarmos ao pé da letra o texto da lei, vale mais a pena exigir vantagem indevida do que solicitar, o que também não faz muito sentido (OLIVEIRA; 2015).

Encerrando as leis que responsabilizam e punem as pessoas físicas pela prática de atos de corrupção, faz-se mister trazer à baila as leis que responsabilizam e punem as pessoas jurídicas pela prática destes atos, sejam pessoas jurídicas de direito privado ou de direito público, entidades, associações, partidos políticos, autarquias, administração pública direta ou indireta, cada um com suas peculiaridades e obedecendo a um tipo de regramento diferente, mais ou menos efetivo. O somatório dessas legislações é o grande divisor de águas quando se fala em responsabilização por atos de corrupção no Brasil.

A primeira e mais importante legislação anticorrupção, em nível nacional, que procura responsabilizar e punir as pessoas jurídicas pela prática de atos de corrupção, é a Lei n. ${ }^{\circ}$ 12.846, de 01 de agosto de 2013, conhecida como Lei Anticorrupção Brasileira, alterada e regulamentada posteriormente, em 18 de março de 2015, pelo Decreto n. ${ }^{\circ}$ 8.420. Nos termos da Lei Anticorrupção Brasileira, a responsabilidade pela prática de atos de corrupção deixou de ser exclusividade das pessoas físicas e passou também a ser atribuída às pessoas jurídicas ${ }^{23}$.

Como mencionado, antes dela, não havia qualquer norma ou lei que responsabilizasse as pessoas jurídicas por atos de corrupção cometidos por seus funcionários, administradores, prepostos, representantes, acionistas e

${ }^{23}$ Conforme artigo 10 da Lei $12.846 / 13$, conforme alterada pelo Decreto 8.420/15. 
prestadores de serviços, contra a administração pública, nacional ou estrangeira, em seu benefício. Veio, portanto, suprir uma lacuna, no direito brasileiro, quanto à punição de pessoas jurídicas, pela prática de atos de corrupção.

Neste sentido, instituiu a responsabilidade objetiva para as pessoas jurídicas praticantes de atos de corrupção e fraudes contra a administração pública, em detrimento da responsabilidade subjetiva, que depende de comprovação e culpa, restrita às pessoas físicas diretamente envolvidas. Institui também, a responsabilidade solidária para as sociedades controladoras, controladas, coligadas e consorciadas ${ }^{24}$.

Pelos termos da lei, estão sujeitas aos seus regramentos as sociedades empresárias e simples, personificadas ou não, as fundações, associações de entidades ou pessoas, e sociedades estrangeiras que tenham sede, filial ou representação no território brasileiro ${ }^{25}$. É importante ressaltar também, que a responsabilização da pessoa jurídica não exclui a responsabilidade individual de seus dirigentes ou administradores ou de qualquer pessoa que tenha participação no ato ilícito ${ }^{26}$.

O artigo $5^{\circ}$ da referida lei, expõe em rol exaustivo quais atos são considerados lesivos à administração pública, como, por exemplo: prometer, oferecer ou dar, direta ou indiretamente, vantagem indevida a agente público, ou a terceira pessoa a ele relacionada (conceito clássico de corrupção); financiar, custear, patrocinar ou de qualquer modo subvencionar a prática de atos de corrupção; e no tocante às licitações e contratos: frustrar, fraudar, impedir, perturbar, obter vantagem ou benefício indevido ${ }^{27}$.

\footnotetext{
${ }^{24}$ Conforme artigo 20 da Lei 12.846/13, conforme alterada pelo Decreto 8.420/15.

${ }^{25}$ Conforme parágrafo único do artigo 10 da Lei 12.846/13, conforme alterada pelo Decreto 8.420/15.

${ }^{26}$ Conforme artigo 30 da Lei 12.846/13, conforme alterada pelo Decreto 8.420/15.

${ }^{27}$ Art. 5 o Constituem atos lesivos à administração pública, nacional ou estrangeira, para os fins desta Lei, todos aqueles praticados pelas pessoas jurídicas mencionadas no parágrafo único do art. 10 , que atentem contra o patrimônio público nacional ou estrangeiro, contra princípios da administração pública ou contra os compromissos internacionais assumidos pelo Brasil, assim definidos: I - prometer, oferecer ou dar, direta ou indiretamente, vantagem indevida a agente público, ou a terceira pessoa a ele relacionada; II comprovadamente, financiar, custear, patrocinar ou de qualquer modo subvencionar a prática dos atos ilícitos previstos nesta Lei; III - comprovadamente, utilizar-se de interposta pessoa física ou jurídica para ocultar ou dissimular seus reais interesses ou a identidade dos beneficiários dos atos praticados; IV - no tocante a licitações e contratos: a) frustrar ou fraudar, mediante ajuste, combinação ou qualquer outro
} 
Caso seja constatada a prática de ato de corrupção, inicia-se o chamado Processo Administrativo de Responsabilização (PAR), cuja competência para instauração e julgamento foi dada à autoridade máxima da entidade que sofreu $\mathrm{o}$ ato lesivo, podendo ser delegada ${ }^{28}$.

$\mathrm{Na}$ sequência, a referida autoridade decidirá pela abertura de investigação preliminar (conduzida por uma comissão) e instauração do PAR ou arquivamento da matéria. Saliente-se que a Controladoria Geral da União (CGU) poderá avocar o PAR em algumas hipóteses, como no caso de omissão da autoridade, complexidade, repercussão e relevância da matéria, entre outros ${ }^{29}$.

Após instaurado o PAR, a pessoa jurídica possui 30 (trinta) dias para apresentar a defesa e a documentação, inclusive a comprovação de eventuais programas de integridade que tenham sido implementados. O PAR possui o prazo de 180 (cento e oitenta) dias para ser concluído, podendo ser prorrogado. Ao final, será emitido relatório contendo a pena, que pode ser integral ou dosimétrica, e a decisão administrativa, da qual caberá recurso no prazo de 10 (dez) dias.

É fundamental ressaltar que a Lei Anticorrupção Brasileira prevê sanções bastante pesadas para quem pratica atos de corrupção, tanto na esfera

expediente, o caráter competitivo de procedimento licitatório público; b) impedir, perturbar ou fraudar a realização de qualquer ato de procedimento licitatório público; c) afastar ou procurar afastar licitante, por meio de fraude ou oferecimento de vantagem de qualquer tipo; d) fraudar licitação pública ou contrato dela decorrente; e) criar, de modo fraudulento ou irregular, pessoa jurídica para participar de licitação pública ou celebrar contrato administrativo; f) obter vantagem ou benefício indevido, de modo fraudulento, de modificações ou prorrogações de contratos celebrados com a administração pública, sem autorização em lei, no ato convocatório da licitação pública ou nos respectivos instrumentos contratuais; ou g) manipular ou fraudar o equilíbrio econômico-financeiro dos contratos celebrados com a administração pública; $V$ - dificultar atividade de investigação ou fiscalização de órgãos, entidades ou agentes públicos, ou intervir em sua atuação, inclusive no âmbito das agências reguladoras e dos órgãos de fiscalização do sistema financeiro nacional.

${ }^{28}$ Art. 8o A instauração e o julgamento de processo administrativo para apuração da responsabilidade de pessoa jurídica cabem à autoridade máxima de cada órgão ou entidade dos Poderes Executivo, Legislativo e Judiciário, que agirá de ofício ou mediante provocação, observados o contraditório e a ampla defesa.

${ }^{29} \S 2$ ㅇ No âmbito do Poder Executivo federal, a Controladoria-Geral da União - CGU terá competência concorrente para instaurar processos administrativos de responsabilização de pessoas jurídicas ou para avocar os processos instaurados com fundamento nesta Lei, para exame de sua regularidade ou para corrigir-Ihes o andamento. 
administrativa quanto na esfera judicial ${ }^{30}$. Na esfera administrativa, existe a previsão da aplicação de multa de $0,1 \%$ a $20 \%$ do faturamento bruto do último exercício social da empresa (ou de até $\mathrm{R} \$ 60$ milhões, caso não seja possível apurar); da publicação da decisão condenatória em veículos de mídia de grande circulação, o que causa grandes danos reputacionais; e, ainda, a aplicação de restrições para participação em licitações e contratação com o poder público.

$\mathrm{Na}$ esfera judicial, por outro lado, existe a previsão de pena de perdimento de bens, direitos e valores; de suspensão ou interdição parcial de atividades; e de proibição do recebimento de incentivos, subsídios, subvenções, doações ou empréstimos de órgãos ou entidades públicas e de instituições financeiras públicas ou controladas pelo poder público, pelo prazo de 1 a 5 anos.

O cálculo da multa se inicia com a soma dos valores correspondentes aos seguintes percentuais do faturamento bruto da pessoa jurídica do último exercício anterior ao da instauração do PAR, excluídos os tributos. São percentuais previstos para aplicação da multa, primeiramente, de $1 \%$ a $2,5 \%$ para a hipótese de haver continuidade dos atos lesivos no tempo; e de $1 \%$ a 2,5\% para tolerância ou ciência de pessoas do corpo diretivo ou gerencial da pessoa jurídica.

Além disso, prevê-se percentuais de $1 \%$ a $4 \%$ para o caso de interrupção no fornecimento de serviço público ou na execução de obra contratada; e de $1 \%$ para a os casos onde a situação econômica do infrator esteja positiva, com base na apresentação do Índice de Solvência Geral (ISG) e do Índice de Liquidez Geral (ILG) em patamares superiores a 1, e ainda a constatação de lucro líquido no último exercício anterior ao da ocorrência do ato lesivo.

Os percentuais se estendem, outrossim, a 5\% para o caso de reincidência, assim definida a ocorrência de nova infração, idêntica ou não à anterior, em prazo inferior a 5 anos, contados da publicação do julgamento da infração anterior.

\footnotetext{
${ }^{30}$ Capítulos III e VI da Lei no 12.846, de 1o de agosto de 2013, conforme alterada pelo Decreto 8.420/15.
} 
Finalmente, são atribuídos novos percentuais, variáveis, de acordo com o valor dos contratos mantidos ou pretendidos com o órgão ou entidade lesado.

Nessa hipótese, serão considerados, na data da prática do ato lesivo, os seguintes percentuais para aplicação das multas: $1 \%$ para contratos acima de $\mathrm{R} \$ 1,5$ milhões; $2 \%$ para contratos acima de $\mathrm{R} \$ 10$ milhões; $3 \%$ para contratos acima de $R \$ 50$ milhões; $4 \%$ para contratos acima de $R \$ 250$ milhões; e $5 \%$ para contratos acima de $\mathrm{R} \$ 1$ bilhões. O somatório dos percentuais, todavia, poderá atingir no máximo $20 \%$.

A lei, no entanto, prevê hipóteses atenuantes na aplicação das penalidades, que poderão literalmente diminuir o percentual da multa a ser aplicada. Neste sentido, o artigo 18 da LAB determina que do resultado da soma dos percentuais de multa aplicados, poderão ser subtraídos outros valores percentuais para dosimetria de pena.

Esses valores, por sua vez, seriam representados pelos seguintes percentuais: $1 \%$ no caso de não consumação da infração; $1,5 \%$ no caso de comprovação de ressarcimento pela pessoa jurídica dos danos a que tenha dado causa; $1 \%$ a 1,5\% para o grau de colaboração da pessoa jurídica com a investigação ou a apuração do ato lesivo, independentemente de acordo de leniência; $2 \%$ no caso de comunicação espontânea pela pessoa jurídica antes da instauração do PAR acerca da ocorrência do ato lesivo; e $1 \%$ a $4 \%$ para comprovação de a pessoa jurídica possuir e aplicar um programa de integridade ${ }^{31}$.

Após julgamento, a decisão administrativa sancionadora será publicada sob a forma de extrato de sentença em jornal de grande circulação e no diário oficial. A multa aplicada, por sua vez, deverá ser paga pela pessoa jurídica no prazo de 30 (trinta) dias da publicação da decisão. Caso não seja paga, haverá inscrição em dívida ativa e cobrança judicial. Como ato final, a pessoa jurídica ainda será incluída no Cadastro Nacional de Empresas Punidas (CNEP).

\footnotetext{
${ }^{31}$ Artigo 18 da Lei $12.846 / 13$, conforme alterada pelo Decreto 8.420/15.
} 
A Lei Anticorrupção instituiu, ainda, o chamado acordo de leniência para as empresas que viessem a praticar atos de corrupção e desejassem redimir-se espontaneamente das ações praticadas. Segundo a LAB, o acordo de leniência poderá ser proposto pela pessoa jurídica desde que ela atenda a uma série de requisitos expressamente previstos na lei, de forma exaustiva.

São considerados requisitos, para este fim, que a empresa (i) seja a primeira a manifestar interesse em cooperar para a apuração de ato lesivo específico; (ii) tenha cessado completamente seu envolvimento no ato lesivo a partir da data da propositura do acordo; (iii) admita sua participação na infração administrativa; (iv) coopere plena e permanentemente com as investigações e o processo administrativo e comparecer, sob suas expensas e sempre que solicitada, aos atos processuais, até o seu encerramento; e (v) forneça informações, documentos e elementos que comprovem a infração administrativa. ${ }^{32}$

Nos termos da legislação, o acordo de leniência, ainda, terá forma oral ou escrita; poderá ser formalizado através de memorando de entendimentos; deverá ser concluído em 180 (cento e oitenta) dias; e no acordo poderão ser pactuadas eventuais isenções das penalidades a serem aplicadas.

Cabe ressaltar que, na medida em que a Lei Anticorrupção Brasileira somente trouxe responsabilização e obrigações de integridade às empresas privadas, ficou evidente uma nova lacuna na legislação de integridade: a falta de regramento em relação às empresas públicas e sociedades de capital misto. Nesta esteira, em 30 de junho de 2016 foi promulgada a lei n. ${ }^{\circ} 13.303^{33}$, que dispôs sobre o estatuto jurídico da empresa pública, da sociedade de economia mista e de suas subsidiárias, também conhecida como Lei das Estatais (LE).

\footnotetext{
${ }^{32}$ Capítulo V da Lei no 12.846, de 10 de agosto de 2013, conforme alterada pelo Decreto 8.420/15.

${ }^{33}$ A Lei dispõe sobre o estatuto jurídico da empresa pública, da sociedade de economia mista e de suas subsidiárias, abrangendo toda e qualquer empresa pública e sociedade de economia mista da União, dos Estados, do Distrito Federal e dos Municípios que explore atividade econômica de produção ou comercialização de bens ou de prestação de serviços, ainda que a atividade econômica esteja sujeita ao regime de monopólio da União ou seja de prestação de serviços públicos.
} 
Como já dito, a Lei das Estatais regulamentou aspectos relacionados às empresas públicas e sociedades de economia mista, principalmente reforçando os valores constitucionais da eficiência, transparência, controle, moralidade e impessoalidade. Ademais, destacou-se a atribuição legal de uma função social para as empresas públicas e sociedades de economia mista.

Além disso, a Lei das Estatais instituiu vedações e impedimentos para que as empresas públicas e sociedades de economia mista pudessem escolher os membros do conselho de administração e cargos de diretoria, atendendo a um desejo bastante manifestado pela sociedade. Determinou, ainda, que as estatais deveriam adotar regras, estruturas e práticas de gestão de risco e controles internos, estruturando políticas de compliance.

Em relação ao controle interno das estatais, a lei criou a obrigatoriedade de implantação de um sistema efetivo, que deveria ser formado por órgãos e unidades com autonomia e independência, como o conselho fiscal, o comitê de auditoria estatutário e a auditoria interna. No que tange a transparência e governança, inúmeras condutas, documentos e relatórios foram previstos e devem ser elaborados, obrigatoriamente, para ampliar o acesso à informação sobre as atividades das estatais.

A principal inovação da Lei das Estatais, porém, foi a obrigação destas elaborarem um regulamento interno de licitações e contratos, que passariam a orientar e balizar as licitações e contratações, permitindo que estas ajustem as normas legais às peculiaridades inerentes a cada uma delas. Dentre as inovações que visam a eficiência das contratações, pode-se citar: a inversão das fases em relação à rotina estatuída pela Lei das Licitações; o desaparecimento das modalidades previstas na referida lei; a criação dos modos de disputa aberto e fechado; e a remuneração do contratado vinculada ao desempenho contratual.

Pode-se citar, adicionalmente, os regimes de execução por contratação integrada e por contratação semi-integrada; a obrigatoriedade de elaboração de matriz de risco para contratação de obras e serviços de engenharia; o aumento dos limites para contratação direta em razão do valor do objeto e a possiblidade 
de alteração destes valores pelo conselho de administração; a adoção de novos critérios de julgamento das propostas; e a adoção de procedimentos auxiliares do processo de licitação.

Apesar de todas essas previsões normativas, e diferentemente de outras entidades jurídicas, como as empresas privadas, as empresas públicas e as sociedades de economia mista, a administração pública direta, composta pela União Federal, Estados e Municípios, bem como os partidos políticos, não foram englobados por nenhuma legislação de integridade brasileira, o que gerou um certo desconforto perante a sociedade.

No caso específico da Administração Pública Direta, como não existe nenhuma lei específica, ela não pode ser responsabilizada pela prática de atos de corrupção e não está obrigada a adotar mecanismos de compliance. Exceção se faz a alguns Estados e Municípios, como o Estado do Mato Grosso (GOVERNO DO ESTADO DO MATO GROSSO; 2016) e o Município de São Paulo (CGMSP; 2016), que possuem programas de integridade pública e se obrigaram, voluntariamente, a seguir normas de integridade e padrões de ética e boa conduta em suas relações com terceiros e com a população.

Em relação aos partidos políticos, todavia, embora não haja leis que os obriguem a cumprir normas de integridade, existem alguns projetos de lei que tentam buscar isso. O primeiro projeto de lei que buscou esse objetivo foi o Projeto de Lei do Senado - PLS n ${ }^{\circ} 60$, de 2017, proposto pelo Senador Ricardo Ferraço ${ }^{34}$. O texto desse PLS visa aplicar aos partidos políticos as normas legais sobre responsabilidade objetiva e compliance e estimular no plano interno código de conduta e programa de integridade e auditoria. Referido PLS, no entanto, carece de efetividade pois não prevê penalidades para a prática de atos lesivos e para ilícitos em processos licitatórios.

\footnotetext{
${ }^{34}$ Altera a Lei no 9.096, de 19 de setembro de 1995, para aplicar aos partidos políticos as normas legais sobre responsabilidade objetiva e compliance e estimular no plano interno código de conduta e programa de integridade e auditoria.
} 
O segundo projeto de lei existente, sobre esse tema, é o PLS n 429 , de 2017, proposto pelo Senador Antonio Anastasia ${ }^{35}$. O texto deste PLS visa aplicar aos partidos políticos as normas sobre programa de integridade. Traz em seu texto algumas medidas bem interessantes, como, por exemplo, a autorização de a ajuizamento, pelo Ministério Público ou por partido político, de representação perante a Justiça Eleitoral, em face do partido inadimplente, em razão da falta de efetividade ou da inexistência do programa de integridade, sujeitando o partido político à suspensão do recebimento do Fundo Partidário, por período mínimo de 3 (três) meses e máximo de 12 (doze) meses.

Além disso, referido PLS exige a realização de diversos atos ligados à integridade, como, por exemplo, a realização de treinamentos periódicos sobre o programa de integridade para filiados, empregados e dirigentes, bem como revisão periódica do referido programa; a implementação de uma estrutura de controle interno e de auditoria interna; a concessão de independência, estrutura e autoridade da instância responsável pela aplicação, monitoramento e fiscalização do programa de integridade, devendo a referida instância se reportar diretamente ao Presidente do partido ou ao Comitê de Ética; e a implantação de políticas específicas e detalhadas de integridade para os gastos.

Prevê, ainda, que deve haver o comprometimento da alta direção; a elaboração de registros contábeis completos; a implementação de canais de denúncia de irregularidades e mecanismos de proteção de denunciantes de boa-fé; a adoção de um procedimento padrão de investigações internas; a aplicação de medidas disciplinares no caso de violação do programa de integridade, assegurada a ampla defesa, podendo o partido expulsar infratores; e, finalmente, a Adoção e divulgação ampla do Código de Conduta e Integridade.

Em sessão do Senado realizada no dia 20 de março de 2019, o referido PLS foi aprovado pela Comissão de Constituição e Justiça (CCJ) do Senado (SENADO FEDERAL; 2019). O próximo passo, por conseguinte, será o julgamento dos

\footnotetext{
${ }^{35}$ Altera a Lei no 9.096, de 19 de setembro de 1995, que dispõe sobre partidos políticos, regulamenta os arts. 14, § 3으, inciso V e 17, da Constituição Federal, a fim de aplicar aos partidos políticos as normas sobre programa de integridade.
} 
recursos impetrados pelos partidos de oposição e o envio para a Câmara dos Deputados para votação.

Sendo assim, ao se analisar o alcance de todas as legislações de integridade existentes no Brasil, percebe-se claramente uma lacuna de responsabilização, na medida em que as diversas leis anticorrupção não têm um padrão ordenado. Deste modo, tem-se entidades jurídicas que são responsabilizadas expressamente pela prática de atos de corrupção, mas não são obrigadas e ter um programa de mitigação desses atos, como as empresas privadas.

Ocorre também de existirem outras entidades que não são responsabilizadas expressamente pela prática de atos de corrupção, mas são obrigadas a ter um programa de mitigação desses atos, como as empresas públicas e sociedades de economia mista. E verifica-se também, finalmente, demais entidades que não são responsabilizadas expressamente pela prática de atos de corrupção, e também não são obrigadas a ter um programa de mitigação desses atos, como a administração pública direta e os partidos políticos.

Essas particularidades podem ser observadas na Figura 7, de elaboração própria, que refletem as diversas legislações anticorrupção existentes no Brasil e sua aplicabilidade prática às diversas entidades jurídicas no país. 


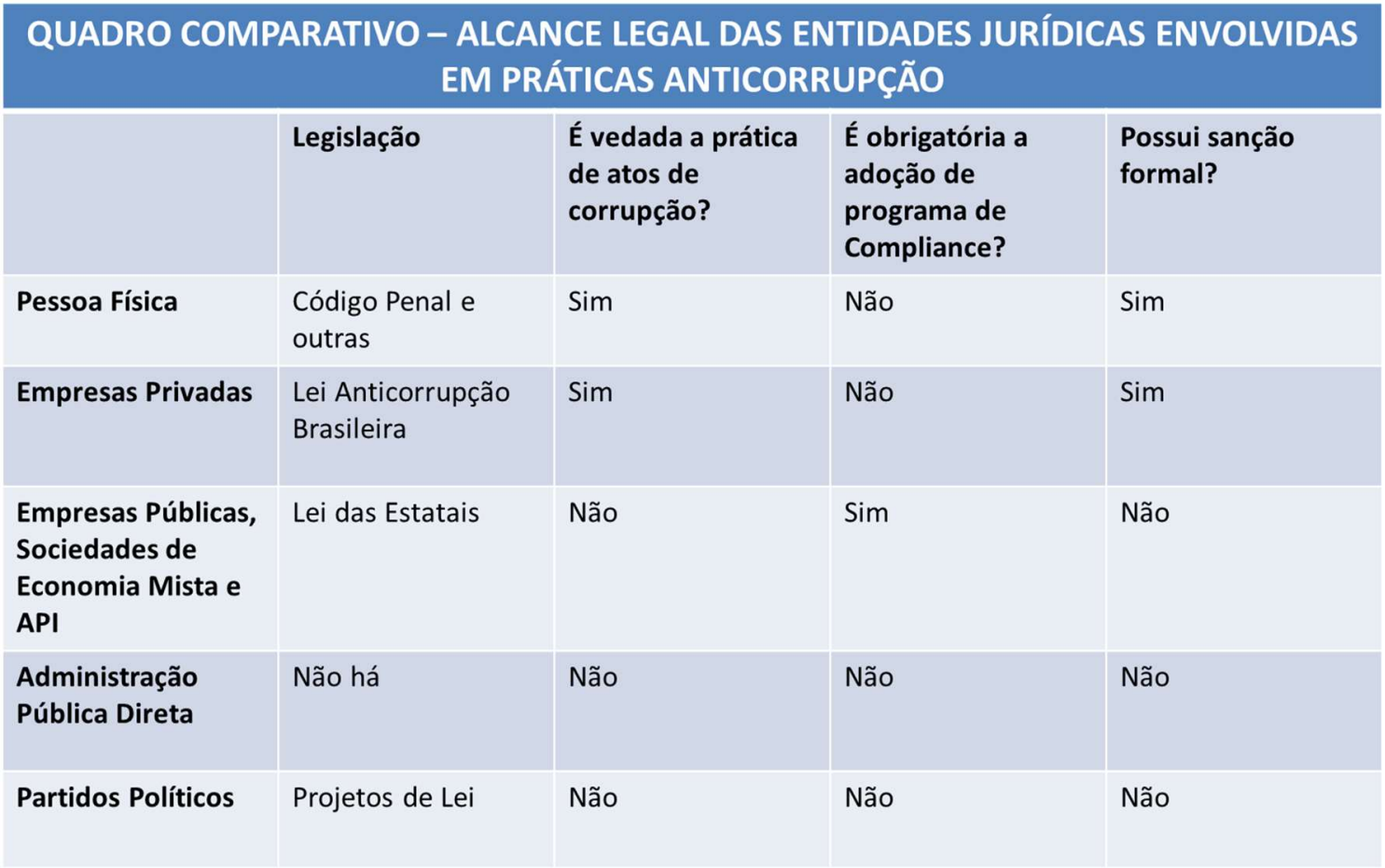

Figura 7 - Quadro Comparativo - Alcance Legal das Entidades Jurídicas Envolvidas em Práticas Anticorrupção

Fonte: Elaboração Própria; 2019. 


\section{CAPÍTULO 4. COMPLIANCE DE INTEGRIDADE}

Este capítulo, por sua vez e como já mencionado, se dedica a explanar sobre o compliance de integridade. Aborda-se, no entanto, o conceito puro de compliance e demais conceitos correlatos. Além disso, expõe as diferentes modalidades de programas que podem ser implementados nas empresas, objetivando a fixação de diretrizes de integridade e o combate à corrupção. Discorre, outrossim, sobre o Programa de Integridade e sua respectiva certificação.

\subsection{Conceito e Classificação do Compliance}

A expressão "compliance" vem do verbo em inglês to comply, que significa cumprir, obedecer. Ser compliance é conhecer as normas da organização, seguir os procedimentos recomendados, agir em conformidade e sentir o quanto é fundamental a ética e a idoneidade em todas as atividades humanas e empresariais. Estar em compliance é estar em conformidade com a lei, valores, princípios e políticas do negócio. Ser e estar em compliance é estar em conformidade com leis e regulamentos internos e externos (RAMALHO; 2016).

Em resumo, significa agir de acordo com a lei, uma instrução interna, um comando ou uma conduta ética, ou seja, estar em compliance é estar em conformidade com as regras internas da empresa, de acordo com procedimentos éticos e as normas jurídicas vigentes. No entanto, o sentido da expressão compliance não pode ser resumido apenas ao seu significado literal. Em outras palavras, o compliance está além do mero cumprimento de regras formais.

Seu alcance é muito mais amplo e deve ser compreendido de maneira sistêmica, como um instrumento de mitigação de riscos, preservação dos valores éticos e de sustentabilidade corporativa, preservando a continuidade do negócio e o interesse dos stakeholders. Podemos entender, portanto, que o compliance integra um sistema complexo e organizado de procedimentos de controle de riscos e preservação de valores intangíveis que deve ser coerente com a estrutura societária, o compromisso efetivo da sua liderança e a estratégia da 
empresa, como elemento, cuja adoção resulta na criação de um ambiente de segurança jurídica e confiança indispensável para a boa tomada de decisão. (CARVALHO; 2019)

Segundo Marcos Assi (2018), o compliance significa cumprir, obedecer e executar aquilo que foi determinado. Em linhas gerais, consiste no dever das empresas de promover uma cultura que estimule, em todos os membros da organização, a ética e o exercício do objeto social em conformidade com a lei. A temática de compliance, embora velha conhecida dos profissionais que atuam com conformidade, controles internos e auditoria, ganhou destaque nos últimos anos, consequência dos grandes escândalos que, no Brasil e no mundo, envolvem a prática de corrupção e lavagem de dinheiro.

Assevera ainda que, para que possamos fazer as coisas certas, devemos conhecer modelos e exemplos de como agir corretamente. Se, com regras, já é difícil estar em conformidade, imaginem sem, em situações em que cada um interpreta à sua maneira a forma de agir? O processo de compliance ou conformidade deve ser para todos, seja pessoa física, seja pessoa jurídica. $O$ importante é que os princípios básicos da ética, conduta, caráter e honestidade sejam seguidos e multiplicados entre todos, na comunidade, em casa, no trabalho, no time de futebol, no condomínio, onde estivermos.

Todavia, exatamente por ser uma expressão bastante ampla, utilizada para expressar a conformidade de forma genérica às leis, normas e regulamentos, o compliance pode ser classificado em vários tipos diversos, como o compliance tributário, o compliance contratual, o compliance anticoncorrencial, o compliance trabalhista.

Neste sentido, estar em conformidade com normas regulatórias, por exemplo, significa estar em compliance regulatório, e assim por diante. A "régua" do compliance, por consequência, é bastante ampla. Isso ocorre na medida em que ela englobaria todos os tipos de conformidade, dividindo o gênero compliance em incontáveis espécies. 
Dentre os tipos de compliance, no entanto, aquele que ocupa o lugar de maior destaque é, sem dúvida, o compliance de integridade, ou seja, aquele voltado para a conformidade às normas de integridade, relacionadas ao comportamento ético e ao cumprimento das diversas leis anticorrupção. $\mathrm{Na}$ "régua do compliance", conforme pode ser observado na Figura 8, o compliance de integridade sem dúvida mereceria uma posição de destaque, dada a sua relevância para o mundo corporativo e para a sociedade como um todo.

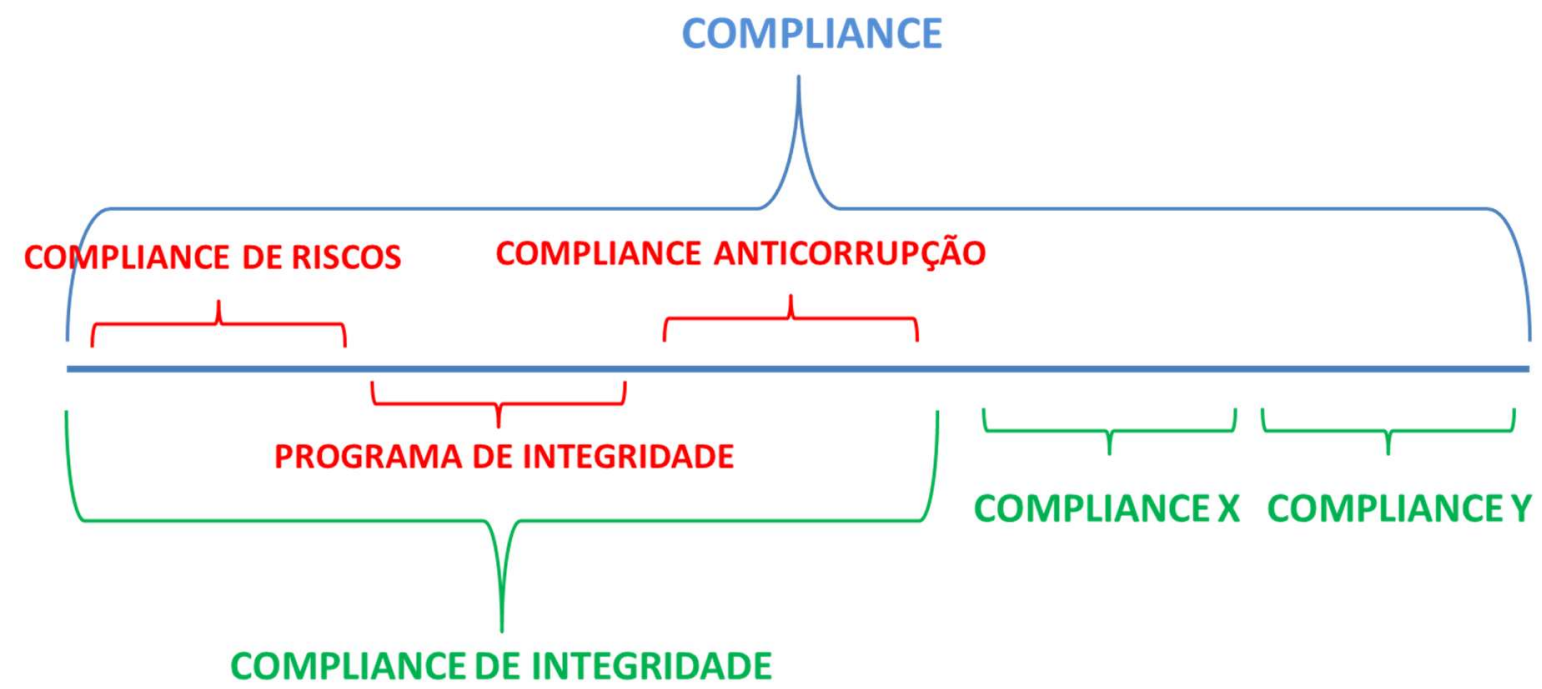

Figura 8 - "Régua do Compliance"

Fonte: Elaboração Própria; 2019.

Para aprofundamento da modalidade conhecida como compliance de integridade, porém, faz-se necessário trazer para discussão alguns conceitos relevantes sobre assuntos direta e intrinsecamente ligados à integridade. Neste sentido, é importante contextualizar, brevemente, temas como ética, moral e integridade.

A palavra ética vem do grego ethos e significa caráter, comportamento. Segundo Alvará Valls (1993), a ética é daquelas coisas que todo mundo sabe o que são, mas que não são fáceis de explicar, quando alguém pergunta. Ainda, conforme mencionado por Fernanda Cintra Lauriano Silva (2010), segundo o Dicionário Aurélio, ética é o estudo dos juízos de apreciação que se referem à conduta 
humana susceptível de qualificação do ponto de vista do bem e do mal, seja relativamente à determinada sociedade, seja de modo absoluto.

A Ética enfatiza a conformidade com padrões idealísticos do bem e mal. Existem, ainda, outras definições: um conjunto de princípios da conduta correta; teoria ou sistema de valores morais; estudo da natureza geral da moral e das escolhas específicas feitas por uma pessoa; as regras ou padrões governando a conduta pessoal ou de membros de uma profissão.

A Ética é, portanto, uma reflexão sobre a própria conduta para saber como agir. Ela trata do comportamento do homem, da relação entre sua vontade e a obrigação de seguir uma norma, do que é o bem e de onde vem o mal, do que é certo e errado, da liberdade e da necessidade de respeitar o próximo. Segundo Cloves Bezerra (2019), em apresentação sobre o tema, a Ética ensina que nossas ações tem efeitos sobre a sociedade; cada homem deve ser livre e responsável por suas atitudes; a justiça é a principal das virtudes; nossos valores têm uma origem histórica; e cada moral é filha do seu tempo.

Integridade, por sua vez, significa a qualidade de alguém ou algo ser íntegro, de conduta reta, pessoa de honra, ética. São exemplos de integridade moral e corporal: o caráter reto, a vida íntegra, a integridade física, dos bens sociais e individuais, integridade da honra e da fama, a integridade da intimidade pessoal, do nome, da imagem e dos sentimentos (WIKIPEDIA; 2019).

O compliance de integridade, portanto, é a vertente do compliance responsável por regular a conformidade às normas, leis, regras e diretrizes ligadas à integridade, ética, moral e bons costumes. Neste sentido, ele abarca todas as disciplinas e metodologias de conduta ética e de prevenção a atos não íntegros, inclusive e principalmente a implementação dos chamados programas de compliance de integridade, ou, somente e de uma forma genérica, programas de compliance.

Nas palavras de Francisco Schertel Mendes (2017), um programa de compliance visa estabelecer mecanismos e procedimentos que tornem o cumprimento da 
legislação parte da cultura corporativa. Ele não pretende, no entanto, eliminar completamente a chance de ocorrência de um ilícito, mas sim minimizar as possibilidades de que ele ocorra, e criar ferramentas para que a empresa rapidamente identifique sua ocorrência e lide da forma mais adequada possível com o problema.

Ainda segundo Edmo Colnaghi Neves (2018), os valores de integridade, honestidade e probidade podem sensibilizar a muitos a ponto de levá-los a investir tempo e dinheiro na implementação e no desenvolvimento de Programas de compliance, outros são mais pragmáticos, vendo nisso um caminho para a sustentabilidade das empresas, afinal, aquelas que perduram e são prósperas oferecem longevidade e prosperidade também aos funcionários, prestadores de serviços, administradores, acionistas e ao próprio governo, que vive da receita tributária gerada pelas empresas bem-sucedidas.

O programa de compliance, portanto, é o procedimento pelo qual a empresa, seja privada ou pública, ou a administração pública, seja direta ou indireta, irá viabilizar a implementação de diretrizes, medidas e mecanismos que assegurem a integridade de seus processos; o combate à corrupção; e a disseminação da ética em suas relações sociais, comerciais e institucionais.

\subsection{Programa de Integridade}

Dentre os diversos programas de compliance, o que mais se destaca no Brasil é - Programa de Integridade, introduzido pela Lei Anticorrupção Brasileira e regulamentado pela Controladoria Geral da União (BRAGHINI; 2019). Ele foi criado com o objetivo de proporcionar às empresas a possibilidade de obter uma dosimetria da pena eventualmente a ela aplicada pela prática de atos de corrupção. O Decreto n. ${ }^{\circ}$ 8.420/2015, em seu Capítulo IV, dispõe sobre o Programa de Integridade ${ }^{36}$, e a própria CGU, todavia, em seu manual Programa

\footnotetext{
${ }^{36}$ Art. 41. Para fins do disposto neste Decreto, programa de integridade consiste, no âmbito de uma pessoa jurídica, no conjunto de mecanismos e procedimentos internos de integridade, auditoria e incentivo à denúncia de irregularidades e na aplicação efetiva de códigos de ética e de conduta, políticas e diretrizes com objetivo de detectar e sanar desvios, fraudes, irregularidades e atos ilícitos praticados contra a administração pública, nacional ou estrangeira.
} 
de Integridade - Diretrizes para Empresas Privadas, é quem regulamenta a implementação do Programa de Integridade ${ }^{37}$.

Neste sentido, a Lei Anticorrupção Brasileira prevê a diminuição gradual da penalidade a ser aplicada à empresa que cometeu o ato lesivo, caso ela possua o chamado Programa de Integridade. Ele é, portanto, um tipo específico de programa de compliance de integridade, só que expressamente previsto na lei.

Segundo a LAB, e como já mencionado no Capítulo 1, Programa de Integridade é o conjunto de mecanismos e procedimentos internos de integridade, auditoria e incentivo à denúncia de irregularidades, bem como à aplicação efetiva dos códigos de ética e de conduta, políticas e diretrizes da empresa, com o objetivo de detectar e sanar desvios, fraudes, irregularidades e atos ilícitos praticados contra a administração pública, nacional ou estrangeira.

Na prática: representa a implementação de padrões de conduta, de ética, treinamentos periódicos, controles internos, políticas e procedimentos específicos para prevenir fraudes e ilícitos no âmbito de processos licitatórios, na execução de contratos administrativos ou em qualquer interação com o setor público, aplicáveis a todos os empregados e administradores.

Mais especificamente: abrange a instituição de normas internas de compliance às leis anticorrupção, a viabilização de canais de denúncia, a elaboração de instrumentos de integridade, bem como o treinamento de pessoal para atendimento às normas internas e à legislação.

\footnotetext{
37 O conteúdo do Manual tem por objetivo esclarecer o conceito de Programa de Integridade em consonância com a Lei no 12.846/2013 e suas regulamentações e apresentar diretrizes que possam auxiliar as empresas a construir ou aperfeiçoar Programa dessa natureza. O documento é eminentemente orientativo e não possui, portanto, caráter normativo ou vinculante. As diretrizes descritas não criam direitos ou garantias, sejam eles relacionados a eventual análise de Programa de Integridade em processo de responsabilização com base na Lei no $12.846 / 2013$ ou a qualquer outro processo ou procedimento nas esferas administrativa ou judicia.
} 
A implementação do Programa de Integridade, todavia, nos moldes da $L A B$, não é obrigatória ${ }^{38}$. Cada empresa é livre para decidir se estatui ou não este tipo de regramento. É claro que ele traz uma série de vantagens para quem o faz, como, por exemplo, a otimização do relacionamento comercial, institucional ou de parceria com empresas multinacionais, que são obrigadas a atender aos normativos internacionais e exigem de seus parceiros a comprovação de programas de integridade.

Além disso representa um manifesto aumento da credibilidade frente ao Poder Público, inclusive para fins de licitação e empréstimos em bancos públicos, como o BNDES (SOARES; 2015). Traz ainda o aumento da credibilidade frente ao mercado, pois valoriza-se a empresa pela transparência e pelo comprometimento com as práticas anticorrupção, gerando também valor ao acionista.

A principal vantagem, no entanto, diz respeito à credibilidade. A empresa que implementa um Programa de Integridade, seja nos moldes específicos da Legislação Anticorrupção Brasileira ou simplesmente como base para um programa mais simples de compliance anticorrupção, pode através desse mecanismo construir uma relação de confiança com o mercado e com a sociedade.

Como já dito, a Controladoria Geral da União, em seu manual Programa de Integridade - Diretrizes para Empresas Privadas, regulamenta a implementação do um Programa de Integridade. Segundo a CGU (2019), ele está baseado em cinco pilares fundamentais, conforme ilustrado na Figura 9: o comprometimento e apoio da alta direção; a identificação ou criação de uma estrutura responsável pelo programa; a realização minuciosa de uma análise do perfil da empresa e dos riscos a que ela pode estar sujeita, considerando-se a possibilidade de cometimento de atos lesivos à administração pública.

\footnotetext{
${ }^{38} \mathrm{~A}$ lei diz que caso a pessoa jurídica apresente em sua defesa informações e documentos referentes à existência e ao funcionamento de programa de integridade, a comissão processante deverá examiná-lo segundo os parâmetros indicados no Capítulo IV, para a dosimetria das sanções a serem aplicadas (grifos nossos). Como a lei não obriga, a empresa pode optar por implementar ou não um Programa de Integridade.
} 
Neste passo, a empresa deve conhecer seus processos e sua estrutura organizacional, identificar sua área de atuação e seus principais parceiros de negócio, bem como seu nível de interação com o setor público; a estruturação das regras e instrumentos de integridade; e a fixação das regras estratégicas de monitoramento contínuo do programa.

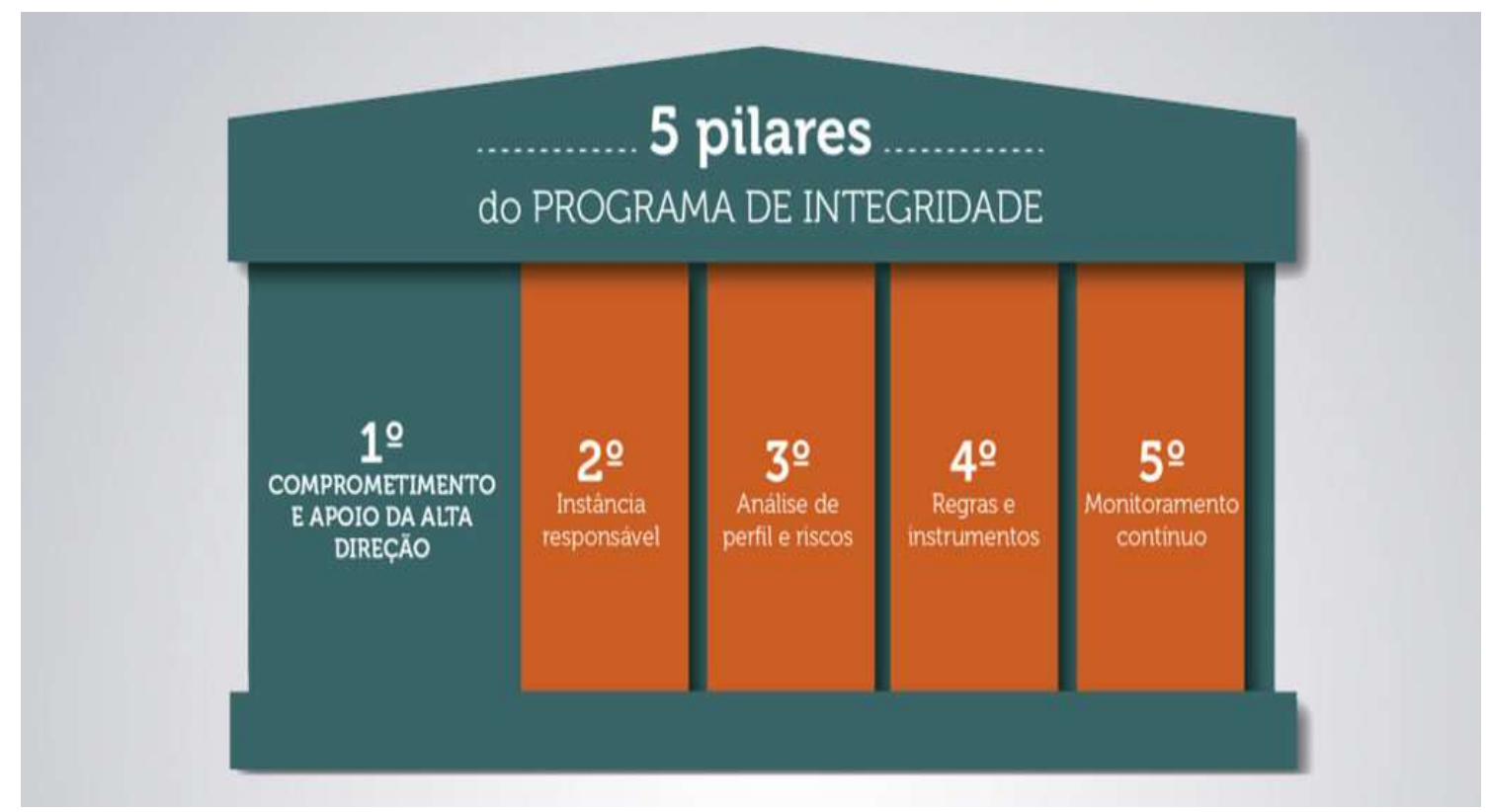

Figura 9 - 5 Pilares do Programa de Integridade

Fonte: Controladoria Geral da União; 2019.

O comprometimento e apoio da alta direção, como pilar número um, exige que a implementação do Programa de Integridade seja realizada de forma top-down, ou seja, de cima para baixo. Neste diapasão, o passo inicial da implementação do programa depende da busca quanto ao comprometimento do administrador da empresa.

A CGU considera o apoio da alta direção como condição indispensável e permanente para o fomento de uma cultura ética que incentive o respeito às leis ao programa. O comprometimento da alta direção da empresa com a integridade e, consequentemente, com o Programa de Integridade, é a base para a criação de uma cultura organizacional de integridade. Possui pouco ou nenhum valor 
prático um programa que não seja respaldado pela alta direção. A falta de compromisso da alta direção resulta no descompromisso dos demais funcionários, fazendo o Programa de Integridade existir apenas "no papel".

Ainda segundo a CGU, os membros da alta direção devem ser exemplo de boa conduta, aderindo prontamente ao Programa de Integridade. Devem declarar pública e ostensivamente a importância dos valores e das políticas que compõem o Programa, seja por intermédio de manifestações explícitas, internas ou públicas, ou de declarações escritas. Além disso, a alta direção deve ser responsável pela supervisão e acompanhamento, direto ou indireto, da aplicação do Programa.

No caso de indícios de falta de efetividade das medidas de integridade, a alta direção deve garantir meios para que sejam feitos os aprimoramentos necessários no Programa e adotadas as medidas corretivas cabíveis. A atitude dos membros da alta direção frente a eventual ocorrência de ato lesivo é de extrema importância. Quando há a participação de membros da alta direção em atos lesivos, fica patente a ausência de comprometimento institucional.

O segundo pilar, referente à instância responsável pelo programa de integridade na estrutura corporativa, dá à empresa a missão de identificar ou criar uma estrutura responsável pelo Programa de Integridade. Essa instância deve ser dotada de autonomia, independência, imparcialidade, recursos materiais, humanos e financeiros para o pleno seu funcionamento.

Na prática, esse pilar diz respeito à criação de um departamento de compliance dentro da empresa, e da criação de uma pessoa para o cargo de compliance officer, que é o executivo responsável pela gestão do departamento, ou seja, pelos recursos, responsabilidades, divulgação, fomento e função institucional do compliance na empresa. Espera-se desse executivo um perfil multidisciplinar, comprometido pessoal e profissionalmente com a cultura de integridade.

O compliance officer deve ser responsável pelo monitoramento dos riscos decorrentes da atividade econômica da empresa. Assim, considerando o foco 
quanto ao pagamento de propina ou de suborno, segundo a empresa de auditoria internacional KPMG (2018), em sua pesquisa de maturidade do compliance no Brasil, devem ser monitorados riscos oriundos de licitações, fiscalizações, licenças, aduana, regulação, vantagens indevidas em transações, contratação de colaboradores ou prestadores de serviços vinculados a pessoas expostas politicamente (PEP), contribuições, doações, brindes, viagens e entretenimentos, consultores e advogados, terceiros fornecedores em geral, pagamentos em espécie, fusões e aquisições.

De outro lado, considerando o foco de outros temas tratados pelo compliance, devem ser monitorados riscos oriundos de combinação de preços e uso de informação de competidores (antitruste), lavagem de dinheiro, fraude, violações ambientais, vazamento de informações regulares, discriminação, trabalho escravo e infantil, patrocínios intermediários, conflitos de interesse, propriedade intelectual, hospitalidades, assédios moral e sexual, e de relacionamento com agentes públicos.

O terceiro pilar, referente à análise do perfil e dos riscos a que a empresa está sujeita, considerando a possibilidade de cometimento de atos lesivos à administração pública, indica que ela deve conhecer seus processos e sua estrutura organizacional, identificar sua área de atuação e seus principais parceiros de negócio, bem como seu nível de interação com o setor público, objetivando mapear, mitigar e tratar as situações de desconformidade à lei.

O quarto pilar que, a seu termo, determina a estruturação das regras e instrumentos inerentes ao Programa de Integridade, reza que com base no conhecimento do perfil e riscos da empresa, deve-se elaborar ou atualizar o código de ética ou de conduta e as regras, políticas e procedimentos de prevenção de irregularidades.

Deve-se, ainda, desenvolver mecanismos de detecção ou reportes de irregularidades (alertas ou red flags; canais de denúncia; mecanismos de proteção ao denunciante), e definir medidas disciplinares para casos de violação e medidas de remediação. Além disso, para uma ampla e efetiva divulgação do 
programa implementado, deve-se também elaborar plano de comunicação e treinamento com estratégias específicas para os diversos públicos da empresa.

O quinto e último pilar, finalmente, orienta que devem ser fixadas regras estratégicas de monitoramento contínuo do programa. Para tanto, é necessário definir os procedimentos de verificação da aplicabilidade dos mecanismos implementados e tratar quaisquer deficiências encontradas.

Estabelecidos os pilares, inicia-se a implementação efetiva do Programa de Integridade pela identificação dos riscos. Nessa instância, faz-se uma análise do perfil da empresa e a identificação dos potenciais riscos quanto à prática de atos lesivos à administração pública, considerando os termos da Lei Anticorrupção Brasileira.

Para esse objetivo, faz-se uma análise dos dados referentes a vários pontos fundamentais: Primeiramente, em relação aos setores do mercado em que a empresa atua, no Brasil e no exterior. Após, será verificada a disposição da estrutura organizacional, considerando a hierarquia interna, o processo decisório e as principais competências de conselhos, diretorias, departamentos ou setores. No momento seguinte, será mapeado o quantitativo de funcionários e demais colaboradores; assim como o nível de interação com a administração pública (CGU; 2019).

Serão considerados principalmente a relevância de processos de obtenção de autorizações, licenças e permissões governamentais em suas atividades, e as participações societárias que envolvam a pessoa jurídica na condição de controladora, controlada, coligada ou consorciada. Serão mapeadas, adicionalmente, situações ou fatores que possam facilitar, camuflar ou contribuir para prática de atos de corrupção.

Nesta seara inclui-se, por exemplo, a participação em licitações; a obtenção de licenças, autorizações e permissões e os contatos com agentes públicos ao submeter-se a fiscalização. Além disso, verifica-se também a contratação de agentes públicos e a contratação de ex-agentes públicos, bem como o 
oferecimento de hospitalidades, brindes e presentes a esses agentes públicos. Finalmente, serão mensuradas as regras para oferecimento de patrocínio e doações, a contratação de terceiros, as fusões, aquisições e reestruturações societárias.

Após a fase inicial de mapeamento dos riscos, serão desenvolvidas políticas com o objetivo de aumentar o controle sobre as situações de risco e diminuir as chances de ocorrência de atos lesivos. O passo seguinte é fazer a revisão dos padrões de conduta e das políticas de ética organizacional da empresa, objetivando verificar sob quais pilares elas estão erigidas e se abrangem as situações de riscos levantadas.

Após essa etapa, parte-se para o ajuste ou construção dos chamados Instrumentos de Integridade, que são o Código de Ética, e o Manual de Políticas Anticorrupção. No Código de Ética deverá ser observada a explicitação dos princípios e valores adotados pela empresa, relacionados a questões de ética e integridade.

Deverão ser mencionadas também as políticas para prevenir fraudes, atos de corrupção, e atos ilícitos de qualquer natureza. Além disso, deve haver vedação expressa a oferecimento de vantagem indevida; prática de fraudes em licitações e contratos; e embaraço à ação de fiscalização pelo poder público.

Já em âmbito do Manual de Políticas Anticorrupção, não basta seguir uma só regra, haja vista tratar-se de um leque muito mais abrangente. Nesta seara, deverão ser abordadas diversas políticas mitigatórias, e não apenas uma como usualmente praticado.

Este documento deverá abranger diretrizes para políticas de relacionamento com o Poder Público; oferecimento de hospitalidade, brindes e presentes a agentes públicos; relativa a registros e controles contábeis; contratação de terceiros; e reestruturações societárias; patrocínios e doações. Além disso, deverá prever as medidas disciplinares para violação às regras de integridade e, também, as ações de remediação à ocorrência de atos de corrupção. 
Após a construção dos chamados instrumentos de integridade, serão fixadas as bases para o desenvolvimento de uma cultura de integridade na empresa, contemplando diversos planos de ação. Todo esse processo, obviamente, necessita de um canal de divulgação.

E é por isso que outro ponto fundamental é a busca de canais efetivos de comunicação, incluindo um canal de denúncias. Através desse canal, os valores e as linhas gerais sobre o programa deverão estar disponíveis, devendo ser amplamente divulgados a todos. E tudo isso para criação de uma cultura corporativa.

Chega-se então a uma necessidade de capacitação e treinamento periódico das pessoas envolvidas na implementação do Programa de Integridade. Esse treinamento, que pode ser geral ou específico, deverá contemplar as diretrizes teóricas da Legislação Anticorrupção, a aplicação de casos práticos e a cientificação das regras de conduta, código de ética e políticas de integridade da empresa.

Após, finalmente, busca-se a fixação de regras para monitoramento e manutenção do programa, incluindo a implementação de mecanismos de controles internos e a realização de auditorias.

\subsection{Certificação do Programa de Integridade}

O Programa de Integridade é certificado pela Controladoria Geral da União através da concessão do Selo Empresa Pró-Ética ${ }^{39}$. O Programa Selo Empresa Pró-Ética consiste em uma divulgação anual, pela CGU, de uma relação de empresas que adotam voluntariamente medidas de integridade relacionadas à prevenção e ao combate à corrupção.

\footnotetext{
${ }^{39}$ O Pró-Ética resulta da conjugação de esforços entre os setores público e privado para promover no país um ambiente corporativo mais íntegro, ético e transparente. A iniciativa consiste em fomentar a adoção voluntária de medidas de integridade pelas empresas, por meio do reconhecimento público daquelas que, independentemente do porte e do ramo de atuação, mostram-se comprometidas em implementar medidas voltadas para a prevenção, detecção e remediação de atos de corrupção e fraude.
} 
O Selo Empresa Pró-Ética tem por objetivo, por exemplo, reconhecer as boas práticas de promoção da integridade e de prevenção da corrupção em empresas que adotam voluntariamente medidas desejadas e necessárias para criação de um ambiente mais íntegro, ético e transparente no setor privado e em suas relações com o setor público; e conscientizar empresas sobre seu relevante papel no enfrentamento da corrupção ao se posicionarem afirmativamente pela prevenção e pelo combate de práticas ilegais e antiéticas e em defesa de relações socialmente responsáveis.

Além disso, também visa fomentar, no âmbito do setor privado, a implementação de medidas de promoção da ética e integridade e contra a corrupção; e reduzir os riscos de ocorrência de fraude e corrupção nas relações entre o setor público e o setor privado (CONTROLADORIA GERAL DA UNIÃO; 2019).

Para que a empresa interessada possa tentar integrar a lista anual divulgada pelo Pró-Ética, ela deverá fazer a sua inscrição, conforme pode ser observado na Figura 10, e preencher e submeter um formulário eletrônico de solicitação de acesso à plataforma, disponibilizado no sítio eletrônico do Pró-Ética.

Durante o período da inscrição, ela deverá preencher a análise de perfil e responder ao questionário de avaliação, e enviá-lo com documentos que comprovem as respostas fornecidas. 


\section{COMO SE INSCREVER \\ PASSO-A-PASSO}

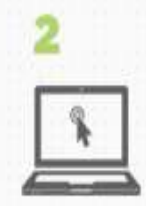

ACESSE O SISTEMA APÓS RECEBIMENTO DO CÓDIGO DE ACESSO, ENTRE NO SITE E CLIQUE EM "ACESSAR SISTEMA"

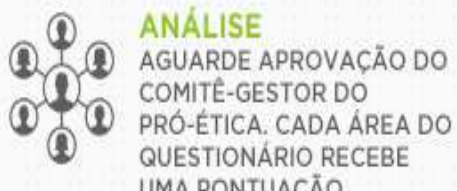
AGUARDE APROVAÇÃO DO QUESTIONÁRIO RECEBE UMA PONTUAÇÄO
PERFIL E AVALIACCĀO PREENCHA A ANÁLISE DE PERFIL E O QUESTIONÁRIO DE AVALIAÇ̄OO.

ANEXE OS DOCUMENTOS NECESSÁRIOS

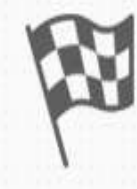

\section{CASO APROVADO}

ASSINE O TERMO DE

COMPROMISSO COM A

ÉTICA E A INTEGRIDADE E

PASSE A SER UMA EMPRESA PRÓ-ÉTICA

Figura 10 - Passo a Passo - Selo Empresa Pró-Ética

Fonte: Controladoria Geral da União; 2019.

O questionário é composto de seis áreas, cada uma com sua respectiva pontuação, conforme pode ser observado na Figura 11. O número total de pontos atingíveis pelas empresas é de 100. Para fins de obtenção da selagem, o número total de pontos que deverá ser atingido pelas empresas é de 70 , desde que tenham obtido pontuações mínimas de quarenta por cento em cada área do questionário.

Os pontos são concedidos nas seguintes proporções: 25 pontos para comprovação do comprometimento da alta direção e compromisso com a ética; 25 pontos para implementação de políticas e procedimentos de integridade; 15 pontos para a efetivação de campanhas de comunicação e realização de treinamentos; 20 pontos para implementação de canais de denúncia e remediação; 10 pontos para realização de análise de risco e monitoramento; e 5 pontos para adoção de regras de transparência e responsabilidade no 
financiamento político e social. Anexa-se a este trabalho o questionário enviado pela CGU, às empresas, como Anexo 1 .

\section{QUESTIONÁRIO DE AVALIAÇÃO}

PONTUAC̄ĀO MÁXIMA POR ÁREA

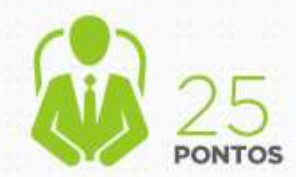

COMPROMETIMENTO DA ALTA

DIREÇÃO E COMPROMISSO

COM A ÉTICA

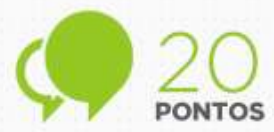

CANAIS DE DENÚNCIA E REMEDIAÇÄO

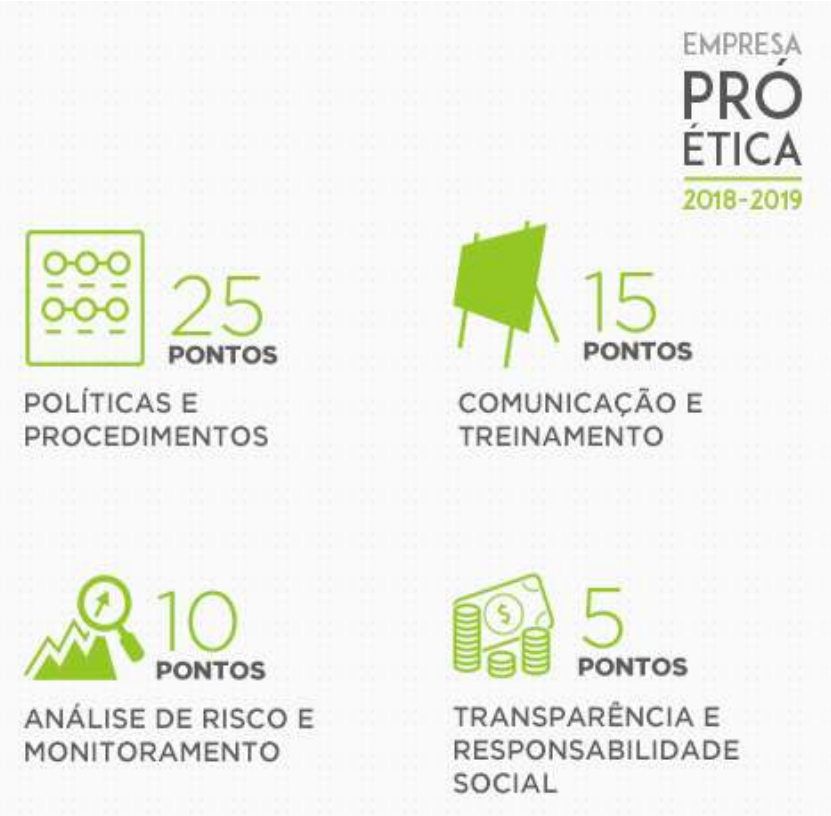

CÁLCULO DA AVALIAÇÃO

PONTUACÄO MINIMA PARA HABILITACÄO

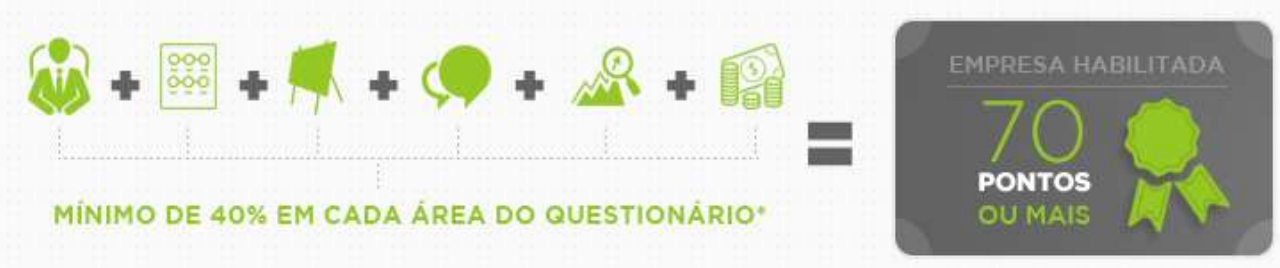

Figura 11 - Questionário de Avaliação - Selo Empresa Pró-Ética

Fonte: Controladoria Geral da União; 2019.

O Comitê Gestor analisará as informações, os documentos encaminhados pelas empresas e fará a avaliação da pontuação. Caso a empresa consiga pontuação suficiente, dentro dos critérios estipulados, terá seu nome divulgado na lista como empresa Pró-Ética. 


\section{CAPÍTULO 5. DISTRIBUIDORAS DE ENERGIA ELÉTRICA E SEU PROTAGONISMO NO CENÁRIO DE INTEGRIDADE}

Este capítulo visa trazer um breve panorama sobre as distribuidoras de energia elétrica no Brasil, enfatizando a sua relevância no cenário econômico nacional, principalmente em relação ao seu protagonismo na criação de uma cultura de integridade e na adoção de programas de compliance.

\subsection{Breve Panorama sobre as Distribuidoras de Energia Elétrica}

O segmento de distribuição se caracteriza como o segmento do setor elétrico dedicado à entrega de energia elétrica para o usuário final. Como regra geral, o sistema de distribuição pode ser considerado como o conjunto de instalações e equipamentos elétricos que operam, geralmente, em tensões inferiores a 230 $\mathrm{kV}$, incluindo os sistemas de baixa tensão (ABRADEE; 2019).

O sistema de distribuição de energia é aquele que se confunde com a própria topografia das cidades, ramificado ao longo de ruas e avenidas para conectar fisicamente o sistema de transmissão, ou mesmo unidades geradoras de médio e pequeno porte, aos consumidores finais da energia elétrica (ABRADEE; 2019).

A conexão, o atendimento e a entrega efetiva de energia elétrica ao consumidor do ambiente regulado ocorrem por parte das distribuidoras de energia. A energia distribuída, portanto, é a energia efetivamente entregue aos consumidores conectados à rede elétrica de uma determinada empresa de distribuição, podendo ser rede de tipo aérea (suportada por postes) ou de tipo subterrânea (com cabos ou fios localizados sob o solo, dentro de dutos subterrâneos).

Do total da energia distribuída no Brasil, dentre as distribuidoras associadas à Associação Brasileira de Distribuidores de Energia Elétrica (ABRAEDEE), o setor privado é responsável pela distribuição de, aproximadamente, $60 \%$ da energia, enquanto as empresas públicas se responsabilizam por, aproximadamente, 40\% (ABRADEE; 2019). 
Assim como ocorre com o sistema de transmissão, a distribuição é também composta por fios condutores, transformadores e equipamentos diversos de medição, controle e proteção das redes elétricas. Todavia, de forma bastante distinta do sistema de transmissão, o sistema de distribuição é muito mais extenso e ramificado, pois deve chegar aos domicílios e endereços de todos os seus consumidores (ABRADEE; 2019).

As redes de distribuição são compostas por linhas de alta, média e baixa tensão. Apesar de algumas transmissoras também possuírem linhas com tensão abaixo de $230 \mathrm{kV}$, as chamadas Demais Instalações da Transmissão (DIT), grande parte das linhas de transmissão com tensão entre 69 kV e 138 kV são de responsabilidade das empresas distribuidoras. Essas linhas são também conhecidas no setor como linhas de subtransmissão.

Além das redes de subtransmissão, as distribuidoras operam linhas de média e baixa tensão, também chamadas de redes primária e secundária, respectivamente. As linhas de média tensão são aquelas com tensão elétrica entre 2,3 kV e $44 \mathrm{kV}$, e são muito fáceis de serem vistas em ruas e avenidas das grandes cidades, frequentemente compostas por três fios condutores aéreos sustentados por cruzetas de madeira em postes de concreto (ABRADEE; 2019).

As redes de baixa tensão, com tensão elétrica que pode variar entre 110 e 440 $V$, são aquelas que, também afixadas nos mesmos postes de concreto que sustentam as redes de média tensão, localizam-se a uma altura inferior. As redes de baixa tensão levam energia elétrica até as residências e pequenos comércios/indústrias por meio dos chamados ramais de ligação. Os supermercados, comércios e indústrias de médio porte adquirem energia elétrica diretamente das redes de média tensão, devendo transformá-la internamente para níveis de tensão menores, sob sua responsabilidade (ABRADEE; 2019).

Pode-se dizer, por fim, que o setor de distribuição é um dos mais regulados e fiscalizados do setor elétrico; além de prestar serviço público sob contrato com o órgão regulador do setor, a Agência Nacional de Energia Elétrica (ANEEL), a própria Agência edita Resoluções, Portarias e outras normas para o 
funcionamento adequado do setor de Distribuição, sendo muito rigorosa com sua fiscalização. Um exemplo são os Procedimentos de Distribuição (PRODIST), o qual dispõe disciplinas, condições, responsabilidades e penalidades relativas à conexão, planejamento da expansão, operação e medição da energia elétrica.

O Brasil tem 56 concessionárias de distribuição de energia, atendendo 82,5 milhões de consumidores, segundo dados da ABRADEE. As 56 distribuidoras que atuam no país são de propriedade privada e também estatais, onde se destacam os grandes grupos econômicos detentores de concessões em diferentes regiões do país, conforme Tabela 1.

Tabela 1 - Brasil - Empresas Concessionárias de Distribuição de Energia Elétrica ABRADEE.

\begin{tabular}{|l|}
\hline $\begin{array}{l}\text { BRASIL - EMPRESAS CONCESSIONÁRIAS DE DISTRIBUIÇÃO DE } \\
\text { ENERGIA ELÉTRICA }\end{array}$ \\
\hline 1. Cooperativa Aliança \\
\hline 2. Centrais Elétricas do Pará S/A \\
\hline 3. Companhia Energética de Pernambuco \\
\hline 4. Companhia Energética do Maranhão \\
\hline 5. Companhia Hidroelétrica São Patrício \\
\hline 6. Companhia Campolarguense de Energia \\
\hline 7. Companhia de Eletricidade do Estado da Bahia \\
\hline 8. Companhia Energética do Rio Grande do Norte \\
\hline 9. Companhia Paulista de Força e Luz \\
\hline 10. Companhia Piratininga de Força e Luz \\
\hline 11. Companhia Luz e Força Santa Cruz \\
\hline 12. EDP Espírito Santo - Distribuição de Energia Elétrica S/A \\
\hline 13. EDP São Paulo - Distribuição de Energia Elétrica S/A. \\
\hline 14. Elektro Eletricidade e Serviços S/A \\
\hline 15. Metropolitana Eletricidade de São Paulo S.A. \\
\hline 16. Enel Distribuição Ceará \\
\hline 17. Enel Distribuição Goiás \\
\hline 18. Enel Distribuição Rio \\
\hline
\end{tabular}


19. Energisa Borborema - Distribuidora de Energia S/A

20. Energisa Minas Gerais - Distribuidora de Energia S/A

21. Energisa Mato Grosso do Sul - Distribuidora de Energia S/A

22. Energisa Mato Grosso - Distribuidora de Energia S/A

23. Energisa Nova Friburgo - Distribuidora de Energia S/A

24. Energisa Paraíba - Distribuidora de Energia S/A

25. Energisa Sergipe - Distribuidora de Energia S/A

26. Energisa Sul-Sudeste - Distribuidora de Energia S/A

27. Energisa Tocantins - Distribuidora de Energia S/A

28. Força e Luz Coronel Vivida Ltda.

29. Iguaçu Distribuidora de Energia Elétrica Ltda.

30. Jari Energética S/A. - JESA

31. Empresa Força e Luz João Cesa Ltda

32. Light Serviços de Eletricidade S/A

33. Muxfeldt, Marin \& Cia Ltda.

34. Usina Hidroelétrica Nova Palma (UENPAL)

35. Hidroelétrica Panambi S.A (HIDROPAN)

36. Rio Grande Energia S/A

37. RGE SUL

38. Empresa Luz e Força Santa Maria S/A

39. Companhia Sul Sergipana de Eletricidade

40. Empresa Força e Luz de Urussanga Ltda. (EFLUL)

41. Departamento Municipal de Energia de Ijuí

42. DME Distribuição S/A

43. Centrais Elétricas de Carazinho S/A

44. Companhia de Eletricidade do Amapá

45. CEB Distribuição S/A

46. Companhia Estadual de Distribuição de Energia Elétrica

47. Centrais Elétricas de Santa Catarina S/A

48. CEMIG Distribuição S/A

49. Companhia Energética de Roraima

50. Copel Distribuição S/A 


\begin{tabular}{|l|}
\hline 51. Eletrobrás Distribuição Acre \\
\hline 52. Eletrobrás Distribuição Alagoas \\
\hline 53. Eletrobrás Distribuição Amazonas Energia \\
\hline 54. Eletrobrás Distribuição Piauí \\
\hline 55. Eletrobrás Distribuição Rondônia \\
\hline 56. Eletrobrás Distribuição Roraima \\
\hline
\end{tabular}

A receita bruta dessas empresas naquele ano totalizou $R \$ 243$ bilhões, representando $3,7 \%$ de participação no Produto Interno Bruto - PIB e empregando 196,3 mil funcionários (EPE; 2018).

Os dados da ABRADEE (2019) também apontam que, a cada ano, ocorrem 1,8 milhão de novas ligações de energia pelas distribuidoras. A carga de energia elétrica gerada no mercado cativo e livre em 2017 totalizou 421,1 mil GWh, sendo 310,5 mil GWh gerada somente pelo mercado cativo.

A regulação econômica do segmento de distribuição é caracterizada por um regime de regulação pelo preço, conforme Lei n ${ }^{0} 9.427 / 1996^{40}$. Esse modelo se caracteriza por dois mecanismos distintos de alteração das tarifas: a Revisão Tarifária Periódica (RTP) e o Reajuste Tarifário Anual (RTA). A RTP ocorre em média a cada cinco anos e é o momento em que se restabelece o equilíbrio econômico da concessão.

Nesse processo, é definida receita compatível com os riscos do negócio, a operação eficiente e a adequada prestação do serviço. Na RTP, define-se também o Fator $\mathrm{X}$, que corresponde a mecanismo de compartilhamento dos ganhos de produtividade das distribuidoras para a modicidade tarifária no período entre revisões (ANEEL; 2019).

Os RTAs ocorrem nos anos em que não há revisão tarifária e visam manter o equilíbrio econômico da concessão estabelecido nos processos de revisão

\footnotetext{
40 Institui a Agência Nacional de Energia Elétrica - ANEEL, disciplina o regime das concessões de serviços públicos de energia elétrica e dá outras providências.
} 
tarifária. Nos processos tarifários, os custos da distribuidora são separados em duas categorias: Parcela $B$, que corresponde aos custos gerenciáveis associados à atividade de distribuição de energia elétrica, e Parcela A, que corresponde aos custos não gerenciáveis, como compra de energia para revenda, encargos de transmissão e encargos setoriais.

Nos RTAs, as tarifas equivalentes aos custos de Parcela B são atualizadas pela variação de um indexador inflacionário, enquanto a tarifa equivalente aos custos não gerenciáveis é revista todos os anos (ANEEL; 2019).

As concessões de distribuição implicam às concessionárias obrigações que compreendem essencialmente a necessidade de se atender toda a população da área geográfica concedida em condições iguais, garantindo isonomia de preços e de forma de atendimento.

O consumo de energia elétrica no país, somou 40.938 GWh em março de 2019, crescendo $2,2 \%$ sobre igual mês do ano anterior. Já no trimestre, com montante acumulado no período de $123.490 \mathrm{GWh}$, o aumento foi de $3,7 \%$. No mês, o consumo nas regiões Sudeste $(2,6 \%)$, Centro-Oeste $(1,8 \%)$ e Sul $(1,5 \%)$ cresceu alinhado à média do país, enquanto os resultados nas duas outras regiões, contrários entre si, foram mais destacados, apresentando crescimento de 6,0\% no Nordeste e retração de 9,8\% no Norte (ANEEL; 2019).

Assim, pelas estatísticas e números levantados em relação às distribuidoras de energia elétrica, percebe-se o quanto esse segmento é economicamente importante e vital para o país. O Governo e a sociedade têm consciência sobre a importância das distribuidoras.

Afinal, são os seus serviços que permitem que a energia elétrica chegue em condições de confiabilidade a 81 milhões de consumidores em todo o território nacional, o que configurava, no ano de 2017 , uma universalização de $99,7 \%$ dos domicílios. De longe, a energia elétrica é o serviço público que alcança maior nível de universalização de serviços públicos no País (CORRÊA; 2017). 
Ainda segundo Corrêa (2017), a população percebe a importância da rede de Distribuição. É fato é que aos olhos do grande público a energia elétrica, no Brasil, é vista como de qualidade muita boa, comprovando que o trabalho perseguido pelas distribuidoras dá resultados em favor dos consumidores.

Não é sem motivos que os investimentos anuais na rede de distribuição alcançam cerca de $\mathrm{R} \$ 14$ bilhões e o número de novas ligações, por ano, supera a casa de 2 milhões.

São esses números que permitem dizer, com segurança, que é importante modernizar o setor elétrico como um todo, mas que também é muito importante preservar a qualidade do serviço de Distribuição, pois é através dele que o consumidor se conecta ao sistema.

\subsection{Protagonismo no Cenário de Integridade}

Conforme já mencionado anteriormente, as distribuidoras de energia elétrica têm exercido um protagonismo no cenário de integridade no Brasil. A prova mais clara disso é exatamente o fato de que não só a maioria das distribuidoras possuem um programa de compliance, mas também que das 23 empresas que receberam a certificação Pró-Ética, que é a mais conceituada certificação de integridade no país (concedida pela CGU), 4 são distribuidoras de energia elétrica, como observado na Figura 12.

Neste sentido, CPFL Energia, Elektro, Enel e Neoenergia, as respectivas holdings dos grupos econômicos que detém o selo Empresa Pró-Ética, agregam juntas 12 distribuidoras de energia elétrica que fornecem energia a quase 2/3 das unidades consumidoras do país (ABRADEE; 2019). Estão inclusas sob o guarda-chuva dessas empresas as seguintes distribuidoras: CPFL Paulista, CPFL Piratininga, CPFL Santa Cruz, RGE, Elektro, Eletropaulo, Coelba, Cosern, Celpe, Coelce, Celg e Ampla. 


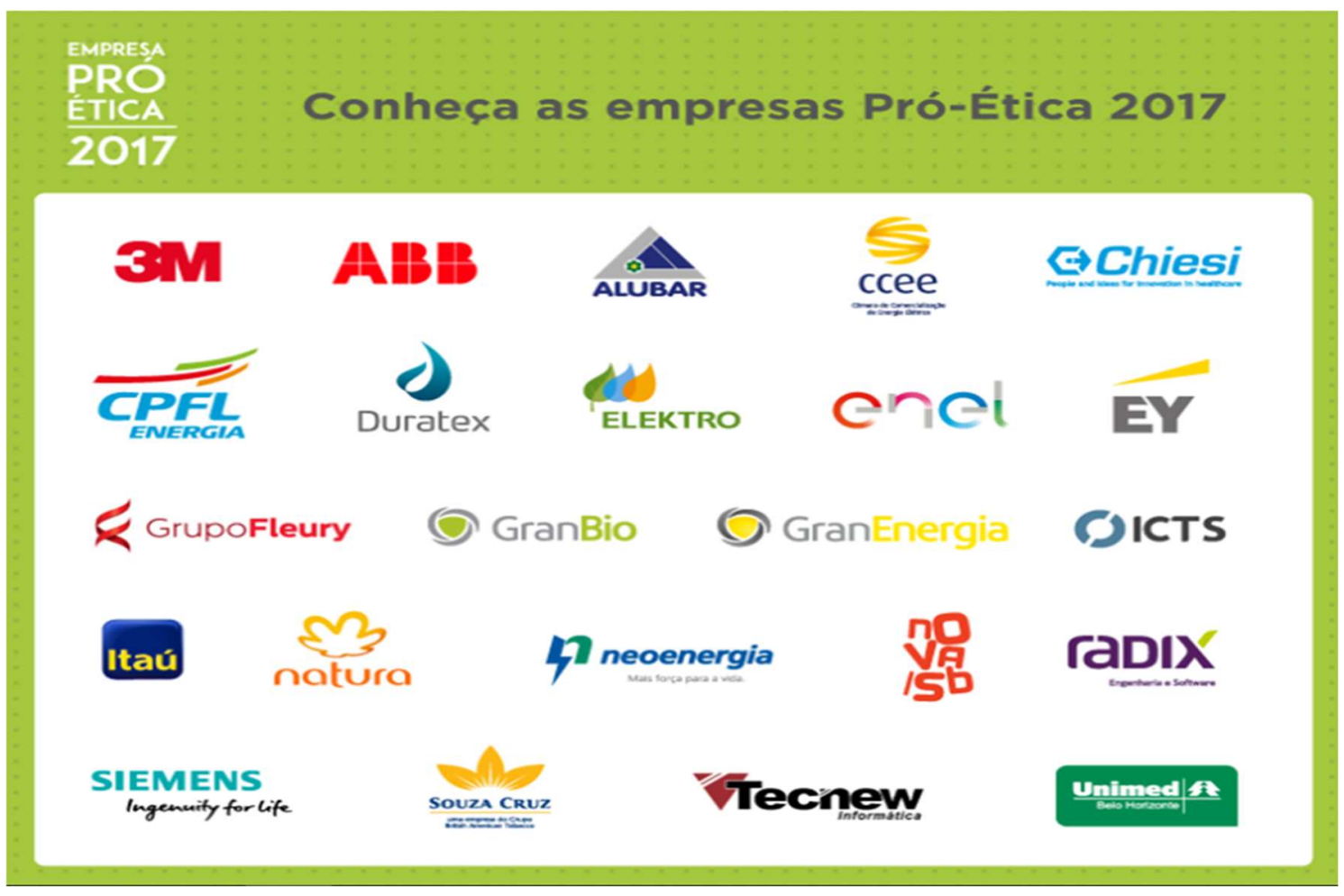

Figura 12 - Relação das Empresas Pró-Ética

Fonte: Controladoria Geral da União, 2019.

Assim, constata-se que quase $2 / 3$ das unidades consumidoras do país tomam serviços de distribuição de energia elétrica de empresas certificadas sob a égide da integridade. Essa constatação, para todos os fins, representa um grande avanço para construção de uma cultura de integridade no país, já que as empresas certificadas são monitoradas pelo Poder Público e devem repassar essa cultura para todos os seus negócios.

Ressalte-se que, esse movimento das grandes distribuidoras em relação à excelência na integridade vem ocorrendo desde 2015, quando iniciaram-se as avaliações para o selo Empresa Pró-Ética. Desde a primeira edição sempre existiu uma preponderância das empresas pertencentes ao setor de energia em participarem do processo de certificação, com a inscrição de várias empresas e participação significativa das distribuidoras (CGU; 2019).

Deve ser observado que essa preponderância se deu em todos os níveis do processo de certificação, ou seja, considerando a solicitação inicial de acesso, a 
finalização do questionário e a aptidão para avaliação. É importante salientar que um grande número de empresas faz a solicitação inicial de acesso. Poucas, todavia, conseguem finalizar o questionário e um número ainda menor é considerado apto para avaliação perante a CGU.

Assim, quando se observam os números econômicos trazidos pelas distribuidoras de energia elétrica, expostos no item anterior deste Capítulo, verifica-se que esse protagonismo é mais que necessário. $E$ isso ocorre na medida em que as distribuidoras, exatamente por representarem um segmento econômico tão relevante, precisam firmar-se no cenário nacional como balizadoras dos princípios de integridade, mitigando os riscos inerentes à prática de atos de corrupção.

Os objetivos desse protagonismo, portanto, podem ser vistos de duas formas: primeiramente no sentido de servir de exemplo aos demais setores de como as empresas economicamente relevantes devem se portar, trazendo uma maior segurança aos milhares de consumidores que tomam seus serviços. Em segundo lugar, para evitar, não só a ocorrência da prática de atos de corrupção, mas principalmente a imputação de penalidades decorrentes da não observância dos ditames previstos na legislação anticorrupção.

Consigne-se, ainda, que a criação e divulgação ao mercado de uma cultura de integridade traz para as distribuidoras de energia elétrica outras consequências economicamente importantes. São elas: o ganho de credibilidade, seja perante o Poder Público (onde as distribuidoras precisam manter uma relação de confiança com os entes regulatórios), ou perante o setor privado (onde está o seu público consumidor); e o ganho econômico, representado pelo aumento do valor de mercado dessas empresas, decorrente do ganho de credibilidade. 


\section{CAPÍTULO 6. ANÁLISE DOS PROGRAMAS DE INTEGRIDADE NAS EMPRESAS DISTRIBUIDORAS DE ENERGIA ELÉTRICA}

Este Capítulo traz uma análise do Programa de Integridade de duas distribuidoras de energia elétrica brasileiras, objetivando verificar o grau de qualidade com que foram implementados, sua conformidade com a Lei Anticorrupção Brasileira e a existência de eventuais lacunas e ou inconsistências.

\subsection{Metodologia de Avaliação e Premissas Utilizadas}

Para alcançar o objetivo proposto na presente dissertação, ou seja, avaliar a qualidade dos Programas de Integridade implementados por duas das maiores distribuidoras de energia elétrica do país, foram realizados diversos passos. $O$ primeiro foi escolher as empresas que melhor se enquadrariam na pesquisa, considerando critérios objetivos ligados ao tema.

Para tanto, buscou-se duas distribuidoras que atendessem aos seguintes requisitos: preliminarmente, que fossem relevantes para o cenário nacional de distribuição de energia elétrica (levando-se em conta o tamanho de sua operação, o número de unidades consumidoras atendidas, o consumo de energia elétrica registrado e o faturamento bruto anual). O principal critério de escolha, no entanto, foi a existência e o grau de aplicação, nessas empresas, de um Programa de Integridade, nos moldes previstos na Lei Anticorrupção Brasileira.

Após avaliação de várias distribuidoras sob o crivo dos mencionados critérios, chegou-se a duas empresas que preencheram plenamente os requisitos destacados, e que concordaram em fazer parte da pesquisa ora proposta. Referidas empresas, todavia, não autorizaram a divulgação expressa dos seus nomes. Sendo assim, foi adotada neste trabalho a postura de não as citar expressamente, divulgando-se apenas suas características gerais e os resultados obtidos. 
Deste modo, em relação às duas distribuidoras avaliadas, podem ser divulgadas as seguintes características, presentes na data de realização da pesquisa: primeiramente, que ambas as empresas atendiam a mais de cinco milhões de consumidores em suas respectivas áreas de concessão (sendo considerado, para fins desta estatística, o somatório do número de consumidores de cada uma das empresas distribuidoras pertencentes ao mesmo grupo econômico).

Além disso, ambas as empresas distribuíam mais de 100.000.000 MWh em energia elétrica ${ }^{41}$, possuindo faturamento bruto anual acima de $\mathrm{R} \$ 10$ bilhões $^{42}$. Finalmente, deve ser ressaltado que ambas as empresas tinham implementado um Programa de Integridade, baseado na Lei Anticorrupção Brasileira ${ }^{43}$.

Convém salientar que os dados acima relatados são públicos, divulgados pelos competentes órgãos reguladores, em relação às distribuidoras avaliadas. Após a definição das premissas e definidas as distribuidoras, bem como os respectivos critérios de avaliação, foi realizada uma pesquisa sobre o Programa de Integridade existente em cada uma delas.

Consigne-se, adicionalmente, que os dados, materiais e informações para a pesquisa foram coletados de três fontes diferentes: em primeiro lugar, através das respostas a um questionário de avaliação, formulado especialmente para esta pesquisa e utilizado em uma entrevista presencial, na sede das distribuidoras, conforme teor refletido no Anexo 2. As entrevistas foram feitas com os executivos de compliance de cada uma das duas empresas, entre os meses de outubro e dezembro de 2018. As respostas das distribuidoras estão inseridas nos Anexos 3 e 4.

A segunda fonte de coleta foram os respectivos sites de internet das distribuidoras (endereços eletrônicos dessas empresas, disponíveis na rede

\footnotetext{
${ }^{41}$ Conforme divulgado pela Agência Nacional de Energia Elétrica (ANEEL), em sua página oficial na rede mundial de computadores.

${ }^{42}$ Conforme verificado nas informações públicas divulgadas pela Comissão de Valores Mobiliários (CVM), em sua página oficial na rede mundial de computadores.

${ }^{43}$ Conforme divulgado pela Controladoria Geral da União (CGU), em sua página oficial na rede mundial de computadores.
} 
mundial de computadores). Nos sites foram encontradas todas as informações virtuais disponíveis ao público, incluindo documentos eletrônicos e as diretrizes gerais de integridade. A terceira fonte, ao contrário da segunda, se deu pela verificação de alguns documentos físicos disponibilizados, como contratos e políticas existentes.

Após a coleta e verificação de todas as informações disponibilizadas, iniciou-se a avaliação dos Programas de Integridade, que se deu com base em uma premissa que merece ser destacada: as empresas analisadas são concessionárias de serviços públicos de distribuição de energia elétrica. Como consequência, devem ser considerados, na avaliação, não apenas os riscos de integridade decorrentes de sua atividade econômica, mas principalmente os riscos de não-conformidade regulatória, já que o não-compliance regulatório pode dar ensejo ao não-compliance de integridade.

Isso ocorre pois o descumprimento das normas regulatórias enseja, com base na legislação competente, a aplicação de sanções pelo poder concedente. Assim, no afã de evitar a imputação de penalidades institucionais ou pecuniárias, a empresa surpreendida em não-compliance regulatório, através de seu corpo diretivo, prepostos ou funcionários, tenderá à prática de atos lesivos contra a administração pública. E é esse fato, por sua vez, que tipificará o não-compliance de integridade, colocando em risco todo o Programa de Integridade.

Deste modo, a base da pesquisa foi estruturada de modo a se fazer, primeiramente, uma avaliação dos Programas de Integridade das distribuidoras sob o ponto de vista estrito de cumprimento dos requisitos legais, considerandose as diretrizes propostas pela Lei Anticorrupção Brasileira e pela Controladoria Geral da União. Adicionalmente, foi realizada também uma pesquisa sobre as políticas de compliance regulatório das citadas empresas, verificando-se eventual risco de integridade sob o ponto de vista da existência de controles para mitigação dos riscos regulatórios.

Como consequência, sob o ponto de vista da integridade, foram analisados os seguintes parâmetros para cada uma das distribuidoras: (i) o comprometimento 
da alta direção e compromisso com a ética; (ii) as políticas e procedimentos internos de integridade; (iii) a efetivação da comunicação e treinamento; (iv) a implantação de canais de denúncia e sua respectiva remediação; (v) a análise de risco e o monitoramento; e, por fim, (vi) o grau de transparência e de responsabilidade no financiamento político e social. Sob o ponto de vista regulatório foram analisadas apenas as políticas de compliance regulatório vigentes em cada umas das distribuidoras.

\subsection{Análise dos Programas de Integridade das Distribuidoras Pesquisadas}

A primeira etapa de avaliação das distribuidoras pesquisadas foi o chamado mapeamento dos mecanismos de integridade. Nesta seara, buscou-se como finalidade mapear tanto a cultura de integridade dessas empresas quanto os riscos atinentes à sua atividade econômica. Para tanto, haja vista a impossibilidade de realização de uma auditoria formal para verificação das informações, optou-se pela análise sistemática dos dados coletados nos questionários de avaliação.

Neste diapasão, foram construídas algumas questões englobando vários pontoschave, relacionados aos Programas de Integridade das distribuidoras avaliadas. Essas questões foram distribuídas estrategicamente no documento denominado questionário de avaliação. Deste modo, nesta primeira etapa, foram analisadas as respostas dadas pelas distribuidoras em contrapartida às perguntas consignadas no referido documento.

Partindo-se dessa premissa, a primeira questão suscitada indagou se haveria algum programa de compliance em vigor nessas empresas, considerando o prisma da integridade, sendo que em caso positivo, deveria ser informada a data em que ele teria sido implementado. A primeira distribuidora respondeu que desde 2014 vem sendo implementado um programa de compliance e que ele, na sequência e conforme regulamentação da Lei Anticorrupção Brasileira, foi aperfeiçoado para o nível de Programa de Integridade. Essa empresa obteve, inclusive, o selo Empresa Pró-Ética, concedido pela CGU. 
A segunda distribuidora avaliada, por sua vez, respondeu que desde 2006 vem implementando o seu programa de compliance. Ele, todavia, foi estruturado para obedecer os moldes da legislação anticorrupção norte-americana (a FCPA). Somente em um segundo momento, a partir de 2016, o referido programa foi adequado para os ditames da Lei Anticorrupção Brasileira, sendo aperfeiçoado para o nível de Programa de Integridade. Essa empresa, também, obteve o selo Empresa Pró-Ética, concedido pela CGU.

A segunda questão suscitada, por sua vez, indagou às distribuidoras se elas teriam algum documento formal de integridade. Este documento poderia ser caracterizado como um código de ética, uma política de conduta ou ainda algum outro instrumento de teor e nomenclatura similar. Ambas as distribuidoras responderam que possuíam um código de ética, estando este documento disponível em seus respectivos sites, na rede mundial de computadores. A análise específica desses respectivos documentos foi realizada mais à frente, ainda neste Capítulo.

A terceira questão apontada, na sequência, indagou sobre como foi o processo de decisão interno para implementar o Programa de Integridade na empresa e qual a respectiva motivação. A primeira distribuidora respondeu que tanto o processo decisório quanto a motivação se deram em linha com as melhores práticas de mercado, já que a empresa possui ações negociadas na bolsa de valores de Nova York e, ainda, na bolsa de valores de São Paulo. O Programa de Integridade, no entanto, originou-se na política anticorrupção da empresa, lançada em 2014, e no sistema de gestão e desenvolvimento do seu código de ética, revisitado em 2016.

Além disso, destacou que a atuação ética e íntegra tem transcendido a questão moral e se tornado um diferencial de negócios para a empresa, o que também motivou a adoção das políticas de integridade. A segunda distribuidora, de outro lado, respondeu que tanto o processo decisório quanto a motivação para estruturação das políticas de compliance vieram como determinação direta do acionista majoritário. Referido acionista, sediado fora do país, trouxe essa 
determinação objetivando cumprir um programa global de ética e integridade, cujas diretrizes foram previstas para aplicação em todo o grupo econômico.

A quarta questão trazida indagou sobre o funcionamento da estrutura de compliance de cada uma das distribuidoras, abrangendo informações sobre recursos, departamentos, reporte de ações e número de funcionários. A primeira distribuidora relatou que possuía em sua estrutura de compliance uma gerência específica abrangendo gestão de riscos, ética e compliance, com 5 profissionais disponíveis. O reporte dessa gerência era realizado para o executivo responsável pela área de auditoria, riscos e compliance, e este, por sua vez, se reportava ao conselho de administração da companhia.

A segunda distribuidora, por seu turno, respondeu que também possuía uma gerência específica de compliance, mas que contava com aproximadamente 11 membros integrantes. O reporte dessa gerência, do mesmo modo que na primeira distribuidora, era realizado para o executivo responsável pela área de auditoria. Este profissional, por outro lado, respondia ao vice-presidente societário e de compliance que, subsequentemente, se reportava ao diretorpresidente. O diretor presidente, finalmente, se reportava ao conselho de administração.

A quinta questão efetuada indagou sobre quais seriam as políticas e procedimentos internos para divulgação do Programa de Integridade das empresas. Neste diapasão, a primeira distribuidora respondeu que detinha uma série de políticas e procedimentos internos específicos, relacionados ao tema, suportados pelos princípios e valores da empresa. Essas políticas seriam divulgadas aos colaboradores e terceiros através do site da empresa e de treinamentos constantes. A segunda distribuidora, de outra ordem, respondeu que embora também divulgue suas políticas no site, possui um cronograma anual de treinamentos e de comunicação para divulgação do Programa de Integridade. Além disso, acrescentou que sempre procura fazer, com certa periodicidade, alguns eventos internos sobre ética, principalmente para funcionários recém contratados, durante seu período de integração. 
A sexta questão trazida pelo documento utilizado na pesquisa, indagou sobre como as distribuidoras lidavam com eventuais conflitos entre o seu Programa de Integridade e outros programas de compliance, adotados por empresas terceiras com as quais ela mantinha relacionamento comercial. A primeira distribuidora respondeu que, nesse caso, era realizada uma análise detalhada e comparativa dos respectivos programas de compliance para tomada de uma decisão. Relatou ainda que, na grande maioria dos casos, verificava-se o alinhamento das boas práticas e o consenso entre as partes. A segunda distribuidora, de outra sorte, relatou que possuía como praxe impor às outras empresas os termos do seu Programa de Integridade e do seu código de ética, prevalecendo as suas políticas.

A sétima questão trazida pelo questionário abordou o tema da política de fornecedores. Destarte, a dúvida suscitada foi no sentido de verificar se as empresas possuíam alguma política específica de compliance para fornecedores, englobando a realização de auditoria e análise reputacional (que verifica a reputação de integridade do fornecedor). A primeira distribuidora respondeu não possuir uma política de compliance com essa especificidade, mas que todos os requisitos necessários à uma boa contratação, estavam previstos, de forma ampla, em outras políticas internas. Ademais, referidos requisitos eram parte integrante de todos os contratos pactuados com fornecedores.

Em relação à análise reputacional, a primeira distribuidora relatou ainda possuir um processo de "background check", que seria aplicado somente aos fornecedores classificados como sensíveis. Deixou de definir, porém, quais os requisitos para que um fornecedor fosse classificado como sensível. A segunda distribuidora, por sua vez, declarou possuir diretrizes internas de contratação, bem como inserir, nos seus contratos com fornecedores, cláusulas de permissão para realização de auditoria de integridade e outras cláusulas específicas de compliance.

A oitava questão efetuada indagou sobre quais seriam os mecanismos de controles internos utilizados pelas empresas, considerando as necessidades do 
Programa de Integridade. Neste sentido, a primeira distribuidora declarou utilizar como mecanismos de controle apenas e basicamente os treinamentos, os monitoramentos e o canal de denúncia. A segunda distribuidora, por outro lado, relatou possuir mecanismos de controles internos puramente administrativos e respaldados apenas pela sua respectiva plataforma de gestão, o SAP44. Costumava fazer, contudo, um monitoramento constante do Programa de Integridade através de auditorias internas e externas.

A nona questão, por sua vez, foi realizada com a intenção de complementar a questão anterior. Nesta seara, indagou-se como era feito o monitoramento interno e externo do Programa de Integridade de cada uma das empresas. Como resposta, a primeira distribuidora limitou-se a dizer que o monitoramento era realizado basicamente por meio de indicadores de auditoria contínua e pelo canal de denúncias. A segunda distribuidora, de forma bem parecida, indicou apenas que esse monitoramento era realizado através de ações de auditoria, tanto em âmbito interno como externo.

A décima questão suscitou a opinião das distribuidoras sobre algo bastante relevante: existiria algum ponto que não foi abordado pelo Programa de Integridade da empresa? A primeira distribuidora respondeu que não, salientando, porém, que estaria em fase de ampliação do programa, identificando outras leis e regulamentos (internos e externos) de maior impacto para efeito de monitoramento e auto avaliação constante. Revelou ainda o desejo de aprimorar eventuais lacunas que porventura existissem. A segunda distribuidora, diferentemente da primeira, revelou que está aprimorando seu controle de gestão e avaliação de riscos, principalmente no tocante à formalização de documentos para comprovação da aplicação do compliance.

\footnotetext{
${ }^{44}$ A plataforma SAP é um sistema integrado de gestão empresarial (ERP) transacional, produto principal da SAP AG, uma empresa alemã, líder no segmento de softwares corporativos, tendo cerca de 86 mil clientes, segundo a própria SAP, em todo mundo, dentre a grande maioria empresas de grande porte. $\mathrm{O}$ sistema procura contemplar a empresa como um todo, dividindo módulos, onde cada módulo corresponde a uma área específica, fazendo a integração das informações para determinado processo.
} 
A décima primeira questão indagou às distribuidoras pesquisadas se existiria alguma política de compliance regulatório em aplicação na empresa. A primeira distribuidora relatou que ainda não possuía uma política específica para esse viés. Contudo, estabeleceu macroprocessos regulatórios que seriam mapeados através de controles avaliados periodicamente. A segunda distribuidora, por sua vez, foi pragmática ao afirmar que não possui essas políticas mapeadas através da área de compliance. Aventou ainda a possibilidade de existir esse tipo de controle através do seu departamento interno de regulação.

A décima segunda questão, ainda sob essa égide, suscitou se as distribuidoras pesquisadas teriam ciência sobre normativos específicos de compliance da ANEEL e, em caso positivo, se os seguiriam. Ambas as empresas relataram a existência de um normativo da ANEEL estabelecendo níveis e práticas de governança, onde cita-se a questão do compliance, e afirma que estão aderentes a estes requisitos ${ }^{45}$.

A décima terceira questão, em continuidade, teve o condão de verificar quais os principais riscos regulatórios a que as empresas estariam sujeitas, e que poderiam dar ensejo a uma situação de não-conformidade. Neste diapasão, a primeira distribuidora relatou apenas que seria necessário estar atenta e monitorar alterações ou criações de novos regulamentos. Citou, como exemplo, a nova lei geral de proteção de dados. A segunda distribuidora, de outro lado, mencionou especificamente os riscos relativos a eventuais manipulações dos indicadores regulatórios disciplinados pela ANEEL ${ }^{46}$, que poderiam dar ensejo a não-conformidades.

\footnotetext{
${ }^{45}$ Está se referindo à Resolução Normativa ANEEL n. 787, de 24 de outubro de 2017, que regulamenta a avaliação da qualidade dos sistemas de governança corporativa a ser aplicada as distribuidoras de energia elétrica. Referida norma determina, genericamente, que as distribuidoras têm que estar em compliance com normas legais e regulatórias.

46 As distribuidoras são avaliadas em diversos aspectos no fornecimento de energia elétrica. Entre eles, está a qualidade do serviço e do produto oferecidos aos consumidores. A qualidade dos serviços prestados compreende a avaliação das interrupções no fornecimento de energia elétrica. Destacam-se no aspecto da qualidade do serviço os indicadores de continuidade coletivos, DEC e FEC, e os indicadores de continuidade individuais DIC, FIC e DMIC. A qualidade do produto avalia a conformidade de tensão em regime permanente e as perturbações na forma de onda de tensão. Destacam-se neste quesito os indicadores coletivos DRPe e DRCe, obtidos a partir da campanha de medição amostral instituída pela ANEEL.
} 
$\mathrm{Na}$ etapa final das entrevistas, foram efetuadas ainda as questões 14 e 15, cujo objetivo foi introduzir às distribuidoras o tema monitoramento de compliance, sob a ótica específica do setor elétrico. Nestes termos, a décima quarta questão indagou se as empresas já haviam implementado esse tipo de monitoramento, enquanto a décima quinta buscou saber se esse tipo de monitoramento deveria ser considerado para inclusão nos seus respectivos Programa de Integridade. A primeira distribuidora respondeu ambas as questões de forma subjetiva, reforçando apenas que possui macroprocessos de conformidade regulatória. A segunda distribuidora, de outro viés, respondeu apenas que desconhecia e que não sabia responder.

Como já dito anteriormente, essa primeira fase da avaliação teve como objetivo apenas fazer uma análise preliminar e não tão aprofundada da cultura de integridade e riscos que as distribuidoras pesquisadas possuíam, considerando estritamente os seus respectivos pontos de vista, consignados nas respostas concedidas. O teor integral e literal das respostas, às questões realizadas, pode ser encontrado nos já mencionados Anexos 3 e 4.

Dando continuidade, a segunda etapa de avaliação das distribuidoras pesquisadas foi caracterizada pela análise efetiva dos seus respectivos Programas de Integridade. Reitere-se que o critério de análise seguiu não só os ditames da Lei Anticorrupção Brasileira, mas também os da Controladoria Geral da União, comparando os Programas existentes em cada uma dessas empresas com os parâmetros e requisitos exigidos pelas normas legislativas e administrativas competentes.

Assim sendo e conforme sugerido pela normatividade, o primeiro critério a ser avaliado em cada uma das empresas diz respeito ao comprometimento da alta direção na implementação do Programa de Integridade e o seu consequente compromisso com a ética. Sob essa ótica, verificou-se que em ambas as distribuidoras a alta direção vinha cumprindo o seu papel. Essa constatação se deu, basicamente, pelo fato de que essas empresas detinham, à época da pesquisa, uma estrutura de compliance bastante robusta e comprometida. 
É notório que tal fato seria impensável se não houvesse um claro engajamento dos órgãos diretivos das empresas. Isso ocorre, na medida em que a estruturação de um Programa de Integridade demanda não só trabalho operacional, mas principalmente a atuação da alta direção na elaboração do planejamento estratégico. E é exatamente através desse planejamento que serão tomadas as decisões de comando balizadoras do Programa, viabilizando as autorizações societárias e a disponibilização da verba necessária.

Para os fins desta avaliação, é importante salientar que a alta direção, para ambas as distribuidoras pesquisadas, é representada pelo seu conselho de administração, seus comitês de assessoramento corporativo (principalmente o comitê de auditoria), e pela diretoria estatutária. No caso da primeira distribuidora avaliada, especificamente, há ainda um fator extraordinário a ser considerado que é a existência de um conselho fiscal "turbinado". Referido órgão acumula não só as competências do conselho fiscal, mas também do comitê de auditoria, trazendo uma maior autonomia na fiscalização do Programa de Integridade.

Adicionalmente, é importante destacar que se verificou, nos respectivos códigos de ética e conduta das distribuidoras avaliadas, uma adesão expressa da alta direção aos princípios de compliance adotados pelas empresas. Isso se dá pela consignação expressa, nos citados instrumentos, de declarações da alta direção apresentando esses documentos e corroborando seus termos, o que indica uma efetiva dedicação dos executivos e sinaliza para o cumprimento desse requisito.

Não obstante esse fato, existe ainda outra questão fundamental a ser verificada ao se tratar do critério comprometimento da alta direção e compromisso com a ética. Essa questão diz respeito a verificar se a empresa possui uma área e/ou uma pessoa específica responsável pela implementação, aplicação e manutenção do Programa de Integridade. Para essa averiguação, todavia, é fundamental saber não só como essa eventual área se organiza e que tipo de estrutura dispõe, mas também se ela possui autonomia e independência para atuar. 
Considerando esse ponto, devem ser retomadas as respostas concedidas pelas distribuidoras no questionário de avaliação, com referência ao funcionamento das suas respectivas estruturas de compliance. Neste sentido e conforme registro, ambas as empresas declararam possuir uma estrutura específica, composta por vários membros (5 profissionais para a primeira distribuidora e 11 para a segunda), nas suas respectivas áreas de compliance.

Em relação ao reporte dos trabalhos, verificou-se que na primeira distribuidora ele era realizado para o executivo responsável pela área de auditoria e este, por sua vez, se reportava ao conselho de administração. No caso da segunda distribuidora, ele também era realizado para o executivo responsável pela área de auditoria, só que este, de outro lado, se reportava ao vice-presidente societário e de compliance, que se reportava ao diretor-presidente, que se reportava ao conselho de administração, criando uma longa cadeia de reportes.

Deste modo, para as duas distribuidoras avaliadas, entende-se que embora haja uma estrutura de compliance identificada e específica, inclusive com disponibilidade de material humano e financeiro, não há nessa estrutura uma logística de reporte dos trabalhos que represente uma independência ideal ou suficiente. Isso ocorre pois em ambos os casos (com mais gravidade para a segunda distribuidora), as áreas específicas de compliance têm de se reportar para uma estrutura hierárquica relativamente longa antes de alcançar a alta administração efetiva (nesse caso, como já dito, representada pelo conselho de administração), o que compromete sua independência.

Tome-se como exemplo, para demonstração do comprometimento mencionado, o tratamento de uma denúncia de fraude hipoteticamente cometida por uma área interna da empresa. Em ambas as distribuidoras, a denúncia seria recepcionada pela área de compliance e esta, por sua vez, teria que se reportar à área de auditoria para encaminhamento. Essa área, só então, daria continuidade à sequência de reportes, até que a denúncia chegasse até a alta administração. Com isso, poderia haver vazamento da informação, haja vista a longa sequência de reportes. Como consequência, o sigilo do processo e o seu tratamento poderiam ficar comprometidos. 
Em continuidade, o segundo critério a ser considerado na avaliação dos Programas de Integridade das distribuidoras pesquisadas diz respeito às políticas e procedimentos adotados pelas duas empresas, referentes a padrões de conduta, política anticorrupção, avaliação de terceiros, controles internos e externos de integridade. Para tanto, deve ser visto primeiramente se a empresa possui algum tipo de código de conduta e quais temas são contemplados nesse documento. Além disso, devem ser verificadas as políticas de integridade da empresa, principalmente sob o foco anticorrupção e de gestão de fornecedores.

Finalmente, devem ser verificados os controles internos e externos da empresa, considerando como foco a política de transparência, e dando-se ênfase à questão contábil e das demonstrações financeiras. Sob esse aspecto, inclusive, deve ser verificado também se a empresa possui políticas e padrões de auditoria interna e externa. Se sim, como isso é feito e, principalmente, como funciona o reporte dessa auditoria dentro da estrutura organizacional. Adicionalmente, devem ser revisitados os controles ligados especificamente ao Programa de Integridade, objetivando aferição de conformidade.

Quanto a este segundo critério, observou-se o seguinte: em relação à primeira distribuidora, notamos a existência de um código de ética bastante alinhado com as melhores práticas de mercado. Neste sentido, o referido documento foi muito bem elaborado, possuindo uma linguagem direta, informal e lúdica, o que o coloca em conformidade regulatória e estratégica. Além disso, verificou-se que ele foi disponibilizado tanto ao público interno da empresa quanto ao público externo, já que o seu respectivo conteúdo estava disponível para ser acessado por qualquer um, através do site da distribuidora na rede mundial de computadores.

Em oposição a essa constatação, observou-se que a segunda distribuidora, apesar de também disponibilizar seu código de ética para o público interno e externo, não o elaborou em conformidade com as melhores práticas de mercado. Isso pode ser concluído, principalmente, pelo fato de que o seu teor reflete um instrumento de linguagem formal, cujo texto foi dividido em seções mais teóricas 
do que práticas. Como consequência, tem-se um documento impositivo, cuja abordagem demonstra um viés unilateral da empresa em relação ao seu público alvo, composto por funcionários e stakeholders ${ }^{47}$.

Cabe ressaltar, todavia, que nenhuma das distribuidoras avaliadas possui um documento compilador de suas políticas de integridade, o que seria recomendável sob o ponto de vista das melhores práticas. Assim, políticas específicas como de relacionamento com o poder público, tratamento de hospitalidades, conflito de interesses, contratação de fornecedores e demais políticas de ética e integridade, encontram-se esparsas dentro da empresa, sem uma compilação lógica, escritas e divulgadas apenas para públicos restritos.

Idealmente, as distribuidoras avaliadas deveriam possuir, além do código de ética, um manual de políticas de integridade reunindo todos esses princípios em um só documento. Esse documento, como já explanado no Capítulo 4, deverá seguir uma linha mais formal, inclusive prevendo as penalidades aplicáveis para a hipótese de eventuais infrações. Sua inexistência nas distribuidoras avaliadas, portanto, representa uma lacuna importante no Programa de Integridade.

Por outro lado, em relação aos controles internos e externos, verificou-se que ambas as distribuidoras estão em completa conformidade. Isso se deu, em grande parte, devido ao fato de que ambas são sociedades por ações de capital aberto, com seus respectivos valores mobiliários comercializados tanto no mercado brasileiro quanto no norte-americano. Deste modo, são obrigadas a seguir padrões internacionais de transparência e divulgação de informações que incluem controles internos e externos, padrões esses que são considerados satisfatórios e conformes também para fins do Programa de Integridade.

Adicionalmente, deve ser também ressaltado que ambas as distribuidoras avaliadas tinham seus controles internos e externos testados e verificados periodicamente através de monitoramento contínuo, realizado por equipes de auditoria, que podem ser internas ou externas. Neste sentido, tendo como foco

47 Stakeholder significa público estratégico e descreve uma pessoa ou grupo que tem interesse em uma empresa, negócio ou indústria. 
primeiramente a auditoria interna, deve ser destacado que ambas as empresas possuíam departamentos bem estruturados e com reporte satisfatório, considerando a estrutura de governança corporativa existente, que executa com propriedade o seu papel institucional de terceira linha de defesa ${ }^{48}$, no padrão determinado pelo Committee of Sponsoring Organizations of the Treadway Commission (COSO $)^{49}$.

Assim, na estrutura constatada, verificou-se que os auditores internos possuíam todas as condições para fornecer aos órgãos de governança e à alta administração as avaliações necessárias, referentes ao Programa de Integridade. Tendo como foco a auditoria externa, por sua ordem, também se verificou que ambas as distribuidoras possuíam processos claros de monitoramento, em linha com aquilo que é exigido pela lei e pelo mercado. Nesta seara, verificou-se uma auditoria externa atuante, que exercia uma função efetiva de controle, dividindo essa função com a auditoria interna.

Ainda neste foco, convém ressaltar que em ambas as distribuidoras a auditoria externa era independente, ou seja, contratada no mercado para exercer suas atribuições e, adicionalmente, obedecer a uma alternância na execução dos seus trabalhos, nos termos da instrução normativa CVM 308/9950. Ressalte-se, por fim, conforme também verificado nas duas distribuidoras, que são obedecidas as regras de conflito de interesses em relação à auditoria externa. Nesse caso, especificamente, quando à vedação da auditoria contratada na prestação de outros serviços, como contabilidade e consultoria na área de administração.

\footnotetext{
${ }^{48}$ As três linhas de defesa, modelo criado pela Comunidade Europeia, separa áreas, funções e profissionais de forma específica para que possam ser coordenadas com eficácia e eficiência, definindo responsabilidades claras e estabelecendo limites para suas responsabilidades, permitindo que haja clareza em como seus cargos se encaixam na estrutura geral de riscos e controles da organização.

${ }^{49}$ Formado originalmente em 1985 para apoiar a National Commission on Fraudulent Financial Reporting, uma iniciativa privada destinada a estudar os aspectos que podem conduzir a relatórios financeiros fraudulentos.

${ }^{50}$ Que dispõe sobre o registro e o exercício da atividade de auditoria independente no âmbito do mercado de valores mobiliários, define os deveres e as responsabilidades dos administradores das entidades auditadas no relacionamento com os auditores independentes. Dispões também sobre o período de alternância das auditorias externas.
} 
O terceiro critério a ser verificado, seguindo-se a metodologia de avaliação definida, diz respeito a como é realizada a comunicação interna do Programa de Integridade das empresas, qual o seu âmbito e, principalmente, qual o seu alcance. Além disso, ainda em relação a esse ponto, deve ser avaliado como é feito o treinamento dos funcionários de cada uma das empresas, considerando a necessidade de capacitação à nova cultura de integridade implementada, aos instrumentos de conduta formalizados e à Lei Anticorrupção Brasileira.

Nesta seara, analisando-se primeiramente a comunicação interna de cada umas das distribuidoras avaliadas, verificou-se que ambas possuíam veículos de divulgação bastante definidos e uma política de comunicação do Programa de Integridade, aos acionistas e respectivos stakeholders, considerada satisfatória. Verificou-se esse fato pela análise das respectivas "intranets" 51 das distribuidoras, onde foram constatadas abas específicas e links para temas de compliance, código de ética e políticas de integridade. Além disso, verificou-se a produção e distribuição de documentos internos, folders e folhetos de comunicação sobre essas ações, dentro da empresa.

Saliente-se que as respectivas políticas de comunicação dos Programas de Integridades das distribuidoras avaliadas, para fins desta avaliação, foram consideradas apenas satisfatórias, na medida em que se restringiram a fazer 0 básico. Isto significa dizer que elas deixaram de inovar ou de adotar outros mecanismos de divulgação mais efetivos, já utilizados por outras empresas do mercado. Tome-se como exemplo de outros mecanismos que poderiam ter sido utilizados, a adoção de programas formais de divulgação, como o programa de Compliance Champions ${ }^{52}$, por exemplo.

\footnotetext{
${ }^{51}$ A intranet é uma rede de computadores privada que assenta sobre a suíte de protocolos da Internet, porém, de uso exclusivo de um determinado local, como, por exemplo, a rede de uma empresa, que só pode ser acessada pelos seus utilizadores ou colaboradores internos.

52 O Programa de Compliance Champions procura formar, entre os colaboradores de uma determinada empresa, não só multiplicadores do seu programa de compliance, mas principalmente pessoas que disseminem cultura de integridade. Ele é implementado na empresa com base no princípio "tone of the people", ou seja, onde a responsabilidade pelo compliance não pertence somente à liderança, ao departamento de compliance (ou compliance officer) ou a "todos indiscriminadamente". Ela é dividida entre todos de uma forma racional, metodológica e coerente.
} 
Outra forma de comunicação bem eficaz, adotada por algumas empresas e que poderia ter sido adotada pelas distribuidoras avaliadas, é a formatação de aplicativos de compliance. Referidos aplicativos podem ser baixados diretamente nos celulares dos funcionários e trazem jogos, mensagens, eventos, o próprio código de ética ou de conduta e divulgam as diretrizes de integridade da empresa, tudo feito de forma eletrônica e em ambiente virtual. Muitos desses aplicativos, inclusive, trazem jogos e casos práticos que refletem situações do dia-a-dia, onde os usuários confrontam situações problemáticas e são desafiados a superá-las.

Passando-se para avaliação dos treinamentos obrigatórios por lei, verificou-se que ambas as distribuidoras também estavam com seus Programas de Integridade conformes, considerando-se o atendimento simples à norma. Isso foi verificado na medida em que elas possuíam programas de treinamento direcionado a todos os seus funcionários, representantes e administradores. Como observado, esse treinamento era realizado tanto presencialmente quanto à distância, sendo que, neste segundo caso, através de acesso remoto viabilizado pelo sistema de tecnologia da informação das respectivas empresas.

Percebeu-se, contudo, que a política de realização de treinamentos de integridade, nas distribuidoras avaliadas, não alcançou seu melhor potencial. Isso foi verificado já que não houve a disponibilização dos treinamentos para toda a cadeia de fornecedores dessas empresas, que ficaram restritos apenas àqueles considerados estratégicos ${ }^{53}$. Assim, considerando-se que idealmente 0 treinamento deveria ter sido disponibilizado para todos os fornecedores, com o objetivo de cientificar $100 \%$ dos envolvidos sobre as diretrizes de integridade da empresa ${ }^{54}$, constatou-se mais essa lacuna.

\footnotetext{
53 Sendo normalmente considerado estratégico, pelas empresas de mercado, os fornecedores que possuem contratos específicos e relevantes, seja pelo volume/montante do fornecimento, pelo valor pago, ou pela essencialidade do produto ou serviço.

${ }^{54}$ Até em virtude da responsabilidade objetiva, prevista na Lei Anticorrupção Brasileira, que imputa à empresa tomadora de serviços responsabilidade pelos atos de corrupção praticados pelos seus prestadores, mesmo sem seu envolvimento, desde que tenha sido beneficiado.
} 
É importante esclarecer que este tipo de falta, que ocorre na realização dos treinamentos referentes à integridade, normalmente é causado por uma conjunção de fatores. Em primeiro lugar, pelo fato da lei não obrigar as empresas a realizarem o treinamento de integridade para os seus fornecedores. Em segundo lugar, pelo fato desse ser um procedimento relativamente custoso, já que pode envolver de poucas a milhares de empresas com necessidade de treinamento ${ }^{55}$. Deste modo, muitas empresas deixam de fazer o treinamento como deveria ser feito, submetendo-se aos consequentes riscos.

Na sequência, o quarto critério a ser analisado nos Programas de Integridade diz respeito à existência de canais de denúncia nas empresas, passando-se pelo tratamento dado e respectiva política de remediação dessas denúncias. Para este ponto, verificou-se nas distribuidoras avaliadas uma diferença relevante de conformidade. Neste diapasão, verificou-se que a primeira distribuidora possui um canal de denúncias criado especificamente para fins de integridade (devidamente identificado como tal e concedendo acesso a links próprios, com essa destinação).

Esse canal tem como objetivo receber consultas, sugestões e formalizar denúncias internas e externas, referentes a temas tratados no código de ética da distribuidora. Saliente-se que o canal assegura, ao denunciante, total sigilo e confidencialidade quanto à denúncia efetuada. Assim, ao se fazer uma denúncia pelos meios disponibilizados pela primeira distribuidora, o denunciante, seja interno ou externo, ingressa em um canal específico voltado para o compliance de integridade e para temas relacionados ao código de ética e às políticas de integridade da empresa. Sem desvios ou interpretações. Além disso, todas as denúncias realizadas são cadastradas e tratadas pela instância responsável, que inicia eventual processo de investigação e dá a devolutiva ao denunciante.

No caso da segunda distribuidora, por outro lado, verificou-se a existência de um canal de denúncias geral (e não específico como verificado na primeira distribuidora), que recebe não só relatos de casos de corrupção e demais temas

\footnotetext{
55 Tome-se como exemplo o caso do Walmart, que é a maior empresa do mundo e que, no Brasil, possui cadastrado mais de 10.000 fornecedores de produtos ou serviços.
} 
de integridade, mas também relatos atinentes a outros assuntos pertinentes ao mercado de distribuição, como, por exemplo, irregularidades no fornecimento de energia elétrica e perdas comerciais. Assim, o canal dessa distribuidora, além de receber denúncias referentes a temas de compliance, recebe ainda denúncias de lâmpadas acesas, furto de energia elétrica e outros temas não relacionados especificamente à integridade (sob a ótica da legislação). Esse fato, por si só, representa um ponto que precisaria ser aperfeiçoado.

Deste modo, embora a segunda distribuidora avaliada disponibilize um canal de comunicação que permita o acolhimento de denúncias de integridade, entendese que ele, por misturar elementos de diferentes searas (inclusive a regulatória) e trazer a denúncia de integridade apenas como parte do todo, não estaria conforme. Verificou-se, porém, que o restante do processo necessário à conformidade de um canal de denúncias, incluindo os passos seguintes ao relato do fato pelo denunciante (identificação, tratamento e remediação), é realizado pela segunda distribuidora avaliada em conformidade com as diretrizes da legislação, principalmente no que tange às orientações da CGU.

Seguindo-se o rito de avaliação, o quinto critério a ser abordado diz respeito à análise dos riscos de fraude e de corrupção a que as empresas estão sujeitas, e sobre como é realizado o monitoramento da aplicação e efetividade do Programa de Integridade. Neste sentido, deve ser verificado se o Programa foi implementado levando-se em conta a construção de uma matriz de riscos efetiva, no caso, focada no risco de cometimento de atos de corrupção. Além disso deve ser verificado quais foram os mecanismos utilizados pela empresa para monitorar a aplicação e efetividade do seu Programa de Integridade.

Assim, para ambas as distribuidoras avaliadas, verificou-se existir conformidade nesse critério, até porque a abrangência dos riscos, nos termos da legislação, diz respeito apenas ao cometimento de atos lesivos contra a administração pública. Dessa forma, o risco de não-conformidade ligado a outras áreas, principalmente as mais complexas (como a regulatória, por exemplo), não são considerados para fins do Programa de Integridade. Com referência ao monitoramento do Programa, tipificado por ações de auditoria dos processos 
implementados, confirmou-se a conformidade, haja vista a robustez da política de auditoria e monitoramento das distribuidoras avaliadas, conforme já mencionado neste Capítulo.

O sexto critério para avaliação de conformidade do Programa de Integridade diz respeito à aferição do nível de transparência das empresas e a verificação de sua responsabilidade quanto ao financiamento político e social. Neste sentido, e explanando-se em primeiro lugar sobre o nível de transparência das distribuidoras avaliadas, verificou-se que ambas eram empresas pertencentes ao Novo Mercado ${ }^{56}$ da Bolsa de Valores Mobiliários do Estado de São Paulo (BOVESPA). Isto, por si só, indica que as distribuidoras avaliadas possuem o mais alto nível de governança corporativa do mercado, ou seja, são comprometidas, entre diversos outros princípios, com a transparência.

Assim, como consequência ao fato de ostentarem a classificação de empresas de Novo Mercado, ambas as distribuidoras avaliadas são obrigadas, por regulação específica, a adotar uma série de medidas voltadas à boa governança. Nesta seara, existem diversas ações de transparência que precisam ser tomadas pelas distribuidoras, como a ampla divulgação ao mercado, acionistas e interessados, de informações referentes a dados financeiros, planejamento estratégico e fatos relevantes. Ao final constatou-se que as distribuidoras avaliadas, neste ponto, estavam em conformidade com os padrões exigidos para fins do Programa de Integridade.

Adicionalmente, mas ainda abrangendo este sexto critério, verificou-se que ambas as distribuidoras avaliadas também possuíam políticas claras com relação a doações filantrópicas e patrocínios culturais, concedendo-lhes conformidade. No que tange ao financiamento político, todavia, não foi constatada condição semelhante, na medida em que as distribuidoras avaliadas são omissas em relação a como seus funcionários devem se portar diante dessa

\footnotetext{
${ }^{56}$ Lançado no ano 2000, o Novo Mercado estabeleceu desde sua criação um padrão de governança corporativa altamente diferenciado. O Novo Mercado conduz as empresas ao mais elevado padrão de governança corporativa.
} 
situação, criando mais uma lacuna em relação às obrigações previstas pela legislação, em relação ao Programa de Integridade.

É importante ressaltar que, desde as eleições de 2018, as pessoas jurídicas não podem mais doar recursos a partidos políticos ${ }^{57}$. No entanto, essa vedação não se aplicou às pessoas físicas, que podem realizar doações de recursos financeiros a partidos e candidatos, desde que sejam equivalentes a até $10 \%$ (dez por cento) dos rendimentos brutos por elas auferidos no ano anterior ao da eleição. Como resultado, muitas empresas passaram a dispor sobre esse tipo de relação, inclusive vedando expressamente esse comportamento em relação a seus funcionários, pois existe a preocupação de que eles possam se envolver em fraudes eleitorais, trazendo dano de imagem à empresa por associação.

Assim, para evitar isso, muitas empresas estão proibindo seus funcionários de realizar este tipo de doação, como a construtora Odebrecht, por exemplo. É claro que se trata de uma intransigência por parte dessas empresas, pois veda direito intrínseco, assegurado às pessoas físicas pela legislação. No entanto é um fato de mercado que, na prática, tem acontecido. Outras empresas, porém, têm tentado agir de maneira diferente, criando regras de monitoramento dos seus funcionários para esse tipo de situação como, por exemplo, a obrigatoriedade de declaração à empresa do valor disponibilizado e da pessoa ou partido para quem foi feita a doação.

O sétimo e último critério a ser considerado nas distribuidoras avaliadas, diz respeito aos riscos de não-conformidade regulatória, com foco na integridade. Primeiramente porque se trata de permissionárias de serviços públicos de distribuição de energia elétrica, ou seja, cuja atividade econômica está lastreada em um setor profundamente regulado, não havendo como prescindir deste tipo de análise. Em segundo lugar, e principalmente, porque o risco de não-

\footnotetext{
${ }^{57}$ A Lei das Eleições (Lei no 9.504/1997) não mais prevê a possibilidade de doações de pessoas jurídicas para as campanhas eleitorais. A mudança foi introduzida pela mais recente Reforma Eleitoral (Lei no 13.165/2015), que ratificou a decisão do Supremo Tribunal Federal, na análise da Ação Direta de Inconstitucionalidade (ADI) 4650, de declarar inconstitucionais os dispositivos legais que autorizavam esse tipo de contribuição.
} 
conformidade regulatória dá ensejo para que se tipifique o risco de nãoconformidade de integridade.

$E$ isso ocorre em função de um silogismo relativamente simples: o fato de a empresa estar não conforme em qualquer aspecto regulatório gera autuação pelo Poder Público. A autuação, por sua vez, é emitida pelo agente público e resulta em um ônus pesado à distribuidora. Assim, para se livrar desse ônus, a distribuidora, através de seus prepostos, funcionários, representantes ou prestadores de serviços, pode vir a cometer atos de corrupção. Esse é um risco bastante perigoso para as empresas, não só pelos altos valores decorrentes da penalização imposta pela infração aos termos da legislação anticorrupção, mas também e inevitavelmente pelo alto potencial de dano à imagem.

Nesta seara, ao se verificar nas distribuidoras avaliadas o processo de mitigação de riscos de integridade decorrentes da seara regulatória, percebemos uma enorme lacuna. $E$ isso ficou evidente pela simples análise das respostas dadas pelas empresas no questionário de avaliação. Ambas as distribuidoras, quando indagadas sobre este aspecto específico, foram transparentes ao afirmar que não possuem uma política de compliance regulatório. Não existe, portanto, um plano específico de mitigação de riscos de integridade, considerando a hipótese dos índices regulatórios não serem atendidos, o que gera uma não-conformidade relevante a ser considerada.

E assim, com a análise deste último critério, concluiu-se a avaliação do Programa de Integridade das distribuidoras escolhidas, nos moldes apregoados pela legislação competente e pela Controladoria Geral da União. Constatou-se, como consequência, que as empresas pesquisadas realmente possuem um alto grau de conformidade à Lei Anticorrupção Brasileira e às normas infralegais pertinentes. Foram verificados, no entanto, diversos pontos de aprimoramento e alguns outros de não-conformidade presentes nos respectivos programas, pontos estes que demandam identificação e tratamento, conforme detalhado no capítulo seguinte, dedicado às considerações finais. 


\section{CAPÍTULO 7. CONSIDERAÇÕES FINAIS}

O desenvolvimento deste trabalho foi motivado por uma série de aspectos. Preliminarmente está o reconhecimento do fato de que a corrupção no Brasil alcançou níveis tão significativos nas últimas décadas que ela foi considerada como sendo de proporções endêmicas. Com efeito, os resultados das pesquisas de percepção da corrupção, realizadas pelo órgão transnacional Transparência Internacional no ano de 2019, situou o Brasil na posição $105^{a}$, ou seja, muito distantes dos primeiros colocados, nos quais estavam os países menos corruptos. Essa deterioração levou a uma crise de credibilidade dos investidores para com o país.

Neste sentido, com a crise de credibilidade instalada, houve repercussões econômicas relevantes, dentre elas o desaquecimento dos investimentos no Brasil, por parte de empresas, entidades e fundos de investimento internacionais. Para combater não só a crise de credibilidade, mas também a própria corrupção em si, as empresas passaram a adotar políticas de compliance de integridade. Conforme visto, tais políticas são efetivadas através da implementação de mecanismos e procedimentos para detectar e sanar desvios, fraudes, irregularidades e atos ilícitos praticados contra a administração pública.

O conjunto desses mecanismos, fundamentais para mitigação dos riscos de integridade nas empresas, foi denominado pela Lei Anticorrupção Brasileira como Programa de Integridade. Assim, empresas brasileiras comprometidas com os valores de ética e integridade passaram a buscar estar em conformidade com a legislação anticorrupção, através da implementação desses Programas. Dentre essas empresas, verificou-se então que aquelas pertencentes ao setor elétrico, principalmente as distribuidoras, seja em função da essencialidade de suas atividades ou ainda pela respectiva relevância econômica, tornaram-se protagonistas nesse movimento.

Como observado no Capítulo de Introdução ao presente trabalho, aproximadamente 1/3 das empresas que detinham o selo Empresa Pró-Ética, como resultado do último processo de certificação, concedido em 2019 pela 
CGU, são do setor elétrico. Dentre essas se destacam as distribuidoras, que representavam mais de $60 \%$ dessas posições. Todavia, como é sabido, o setor elétrico, e particularmente as distribuidoras, pertencem a um mundo corporativo bastante singular, já que são, em sua maioria, permissionárias de serviços do Poder Público, conforme discorrido no Capítulo 5. Como consequência, possuem uma regulação própria bastante específica, o que por si só se traduz num incentivo perverso para que os agentes subordinados a essa intricada regulação se sintam tentados a praticar atos de corrupção.

Neste contexto, o objetivo central desse trabalho foi o de avaliar a qualidade dos Programas de Integridade existentes em duas distribuidoras brasileiras, como uma forma de verificar a sua conformidade em relação à Lei Anticorrupção Brasileira e às orientações da Controladoria Geral da União. Para tanto, foram escolhidas duas distribuidoras com destacada relevância no cenário nacional, em conformidade com os critérios relatados no Capítulo 6. Ademais, com a realização dessa análise, buscou-se também, por se tratar de duas das maiores empresas privadas do Setor Elétrico Brasileiro (consideradas como referência no mercado de distribuição), construir um paradigma de conformidade para as demais empresas desse segmento.

Faz-se importante ressaltar que, ao ser realizada a escolha das distribuidoras que seriam avaliadas, foram encontradas algumas limitações a este trabalho que merecem ser consignadas. Apesar de consultadas previamente e terem aceitado participar da pesquisa, após a realização das entrevistas e resposta aos questionários, ambas as distribuidoras decidiram não autorizar a divulgação expressa dos seus nomes. Ainda foi tentado um pedido de autorização especial, com a assinatura de contratos de confidencialidade limitando a divulgação do material somente para fins acadêmicos, sem, no entanto, que se lograsse êxito. Sendo assim, como já mencionado, foi adotada a postura de citar expressamente seus nomes, divulgando-se apenas suas características gerais. Como consequência, os resultados finais do trabalho puderam ser obtidos através do exame comparativo entre os Programas de Integridade implementados pelas distribuidoras analisadas e os parâmetros previstos na legislação. 
Em relação à estrutura do trabalho, resumidamente, o Capítulo 2 tratou do problema da corrupção. Para tanto, discorreu sobre seus vários conceitos e modalidades de classificação, bem como o seu histórico e evolução em âmbito nacional e internacional, percorrendo a antiguidade até os dias presentes e mostrando como ela se tornou endêmica no Brasil. O Capítulo 3, por sua vez, explanou sobre a legislação anticorrupção e o seu regramento no Brasil e no mundo. Para tanto, realizou um apanhado sobre as convenções supranacionais de integridade, instituídas OCDE, pela OEA e pela ONU, passando pelas duas legislações estrangeiras mais relevantes, o FCPA e o UKBA, e culminando com a legislação anticorrupção brasileira. Da análise realizada neste capítulo depreendeu-se que a legislação brasileira se inspirou fortemente na legislação anticorrupção norte-americana.

Já o Capítulo 4 buscou retratar especificamente o compliance de integridade. Para isso percorreu os diversos conceitos de compliance e demais definições correlatas, expondo a estrutura dos programas específicos voltados para compliance. Neste capítulo, ficou claro que existem vários tipos de programas com esse foco, sendo o mais relevante deles o Programa de Integridade. $O$ Capítulo 5, na sequência, apresentou um breve panorama das distribuidoras de energia elétrica no Brasil. Nele, a ênfase foi dada à relevância das distribuidoras em relação ao seu protagonismo na criação de uma cultura de integridade e na adoção de programas de compliance. Verificou-se, com isso, que as distribuidoras se organizaram para estruturar programas de integridade bastante completos e focados na conformidade com a legislação.

No Capítulo 6 realizou-se uma análise do Programa de Integridade das distribuidoras escolhidas. Como já dito, nessa análise verificou-se o grau de aderência dos Programas de Integridade adotados observando sua conformidade com a Lei Anticorrupção Brasileira e os ditames da Controladoria Geral da União, bem como buscou-se identificar eventuais lacunas. Por fim, o Capítulo 7 tratou dos resultados obtidos e da conclusão. 


\subsection{Análise dos Resultados Obtidos}

A partir da análise realizada foi possível verificar que as distribuidoras avaliadas possuem Programas de Integridade adequados, uma vez que em termos gerais seguem os ditames da legislação competente. Todavia, foi constatado também que os Programas avaliados possuem uma série de pontos que demandam aprimoramento, além de algumas não-conformidades relevantes.

É importante destacar que os pontos de melhoria ou aprimoramento doravante refletidos, representam situações onde se verificou que determinados critérios, utilizados na implementação dos Programas de Integridade das distribuidoras avaliadas, estavam em conformidade básica com a legislação de integridade. Após a análise realizada, todavia, constatou-se que referidos critérios poderiam ser ajustados pelas empresas, com o objetivo de aprimorar seus processos de compliance e mitigar riscos. Por outro lado, os pontos de não-conformidade encontrados representam situações onde se verificou que os referidos não estavam em conformidade com a legislação de integridade. A intenção ao se relatar referidos apontamentos foi, portanto, a de se chamar a atenção para essas falhas e para os riscos que as empresas estão correndo, conforme abaixo indicado:

I. Pontos para aprimoramento:

(i) O primeiro ponto de melhoria ou aprimoramento diz respeito aos instrumentos de integridade das distribuidoras. Fazendo referência ao código de ética, ambas as distribuidoras possuíam instrumentos bastante conformes, inclusive pelo fato de disponibilizá-los ao público externo, através do seu site. As duas distribuidoras avaliadas, no entanto, não detinham um documento único que fosse responsável por compilar suas respectivas políticas de integridade. Assim, políticas específicas como de relacionamento com o poder público, contratação de fornecedores e demais políticas similares, estavam espalhadas dentro da empresa, sendo escritas e divulgadas apenas para públicos restritos, o que reduzia sua aplicabilidade. Deste modo, a sugestão 
seria no sentido de se construir um único instrumento aglutinador das políticas de integridade, em apartado ao código de ética, com linguagem mais técnica e com alcance ampliado.

(ii) O segundo ponto de melhoria, por sua vez, trata da comunicação interna do Programa de Integridade nas distribuidoras avaliadas. Neste sentido, verificou-se que ambas as empresas adotaram, para disseminação dos seus Programas, políticas de comunicação bastante comuns, com a produção de material impresso, folders, palestras e divulgação apenas através dos seus respectivos sites na internet. A sugestão, portanto, seria no sentido de que fossem adotados mecanismos de disseminação mais inovadores, objetivando uma melhor e mais eficaz divulgação aos seus funcionários. Como exemplo desses mecanismos, poderiam ser citados recursos de divulgação diferenciados e já testados com êxito pelo mercado, como o programa de Compliance Champions, explicado no capítulo anterior, ou a formatação eletrônica de aplicativos de compliance e "gamificação" corporativa 58 .

(iii) O terceiro ponto de melhoria, na sequência, faz menção aos treinamentos exigidos para o Programa de Integridade. Apesar de ambas as distribuidoras avaliadas realizarem treinamentos em conformidade com os ditames da lei, eles não englobam a totalidade dos seus fornecedores de produtos e serviços. Esse fato, por si, representa um risco às empresas, já que as sujeitaria à responsabilização objetiva prevista na Lei Anticorrupção Brasileira, que imputa à tomadora de serviços responsabilidade pelos atos de corrupção praticados pelos seus respectivos prestadores. A sugestão, para esse caso, seria a realização de treinamento de $100 \%$ dos prestadores de serviços das distribuidoras avaliadas, realizado preferencialmente por ensino à distância (EAD), com o objetivo de minimizar os custos.

\footnotetext{
58 Gamificação é o uso de mecânicas e características de jogos para engajar, motivar comportamentos e facilitar o aprendizado de pessoas em situações reais, normalmente não relacionados a jogos
} 
(iv) $\mathrm{O}$ quarto ponto de aprimoramento, ainda, diz respeito à formalização do canal de denúncias do Programa de Integridade, neste caso especificamente em relação à segunda distribuidora. Neste sentido, verificou-se que essa empresa implantou o seu respectivo canal de denúncias de modo a receber, por este meio, quaisquer tipos de relatos, e não somente aqueles relacionados a temas de integridade. O canal dessa distribuidora recebia, portanto, denúncias referentes a temas de compliance misturadas com relatos sobre lâmpadas acesas e furto de energia elétrica. Isso, por sua vez, prejudica o processo de apuração, tratamento e retorno dos casos, podendo causar confusão tanto para os denunciantes quanto para os canais de coleta das denúncias. A sugestão, neste ponto, foi a de se criar um canal de denúncias exclusivo para lidar com assuntos de integridade, criando canais de ouvidoria para os demais temas não relacionados.

(v) O quinto e último ponto de melhoria, para finalizar as questões ligadas ao aprimoramento dos Programas de Integridade das distribuidoras avaliadas, diz respeito à política de financiamento eleitoral. Como verificado, em ambas as empresas não existiam regras claras quanto ao financiamento de partidos e candidatos por seus funcionários, gerando potencial dano de imagem por associação. A sugestão, nesse caso, seria no sentido de criar regras para que os funcionários dessas empresas pudessem realizar doações a seus candidatos ou partidos de preferência, porém, mediante declaração à empresa do valor disponibilizado e da pessoa ou partido para o qual foi feita a doação. Com isso, seria mitigado o risco de dano à imagem da empresa, por eventual envolvimento de seus funcionários em esquemas fraudulentos relacionados à eleição.

II. Pontos de não-conformidade:

(i) Em relação aos pontos de não-conformidade, verificou-se o primeiro deles no fato de que nenhuma das distribuidoras apresentou uma estrutura de compliance com independência suficiente para os fins do 
Programa de Integridade. Ter independência suficiente significa garantir que todos os assuntos reportados pela estrutura de compliance sejam devidamente recepcionados, verificados e retornados pela alta direção da empresa, sem que haja influências externas, desvios, vazamento ou retaliação no tratamento desses assuntos. Neste sentido, em ambas as distribuidoras foi verificado que as áreas específicas de compliance têm de se reportar para uma estrutura hierárquica longa antes de alcançar a alta administração efetiva, o que poderia comprometer, portanto, sua independência na identificação e tratamento de situações de não-conformidade. A sugestão, para esse caso, seria a de reduzir o caminho de reporte das áreas de compliance das distribuidoras avaliadas, de modo que os assuntos de integridade fossem reportados diretamente para os respectivos conselhos de administração.

(ii) O segundo e principal ponto de não-conformidade diz respeito à seara regulatória, sob a ótica do compliance. Apesar de ambas as distribuidoras avaliadas possuírem políticas internas de atendimento à regulação setorial, não se observou políticas específicas voltadas ao compliance regulatório, sob o viés da integridade. Esse fato, por sua vez, gera uma alta exposição dessas empresas ao risco de cometimento de atos de corrupção. Isso ocorre pois, como já explicado, o fato de a empresa estar não conforme em qualquer aspecto regulatório gera uma penalização. $\mathrm{Na}$ sequência, para se livrar desse ônus, a distribuidora, através de seus prepostos, funcionários, representantes ou prestadores de serviços, pode vir a cometer atos de corrupção. $E$ isso, como consequência, pode imputar às empresas não só as penalizações previstas nas diversas legislações anticorrupção, mas também prejuízos relevantes, decorrentes do dano à imagem.

Neste sentido, a consolidação dos resultados obtidos pode ser mais bem observada na Figura 13, que descreve as lacunas encontradas de acordo com cada um dos critérios de avaliação utilizados pela Controladoria Geral da União. 


\begin{tabular}{|c|c|c|c|}
\hline & Primeira Distribuidora & Segunda Distribuidora & Observação \\
\hline $\begin{array}{l}\text { Comprometimento da alta } \\
\text { direção / Instância } \\
\text { Responsável }\end{array}$ & Não Conformidade & Não conformidade & $\begin{array}{l}\text { Comprometimento da } \\
\text { independência em função da } \\
\text { estrutura corporativa }\end{array}$ \\
\hline $\begin{array}{l}\text { Políticas e procedimentos } \\
\text { adotados }\end{array}$ & $\begin{array}{l}\text { Não Conformidade e } \\
\text { Ponto de Melhoria }\end{array}$ & $\begin{array}{l}\text { Não conformidade e } \\
\text { Ponto de Melhoria }\end{array}$ & $\begin{array}{c}\text { Política unificada regulatória; } \\
\text { Questão do Código de Ética e } \\
\text { políticas de integridade }\end{array}$ \\
\hline Comunicação e Treinamento & Ponto de Melhoria & Ponto de Melhoria & $\begin{array}{c}\text { Otimização da comunicação } \\
\text { e treinamento integral }\end{array}$ \\
\hline $\begin{array}{l}\text { Canais de Denúncia e } \\
\text { remediação }\end{array}$ & Conforme & Ponto de Melhoria & $\begin{array}{l}\text { Confusão entre canal de } \\
\text { denúncia e ouvidoria }\end{array}$ \\
\hline $\begin{array}{l}\text { Análise de riscose } \\
\text { monitoramento }\end{array}$ & Conforme & Conforme & $\begin{array}{l}\text { Ok. Já que para fins da } \\
\text { legislação, o risco regulatório } \\
\text { não é risco de integridade }\end{array}$ \\
\hline $\begin{array}{l}\text { Transparência e } \\
\text { financiamento político e } \\
\text { social }\end{array}$ & Ponto de Melhoria & Ponto de Melhoria & $\begin{array}{l}\text { Políticas de doação a } \\
\text { partidos políticos }\end{array}$ \\
\hline
\end{tabular}

Figura 13 - "Quadro dos Resultados Obtidos"

Fonte: Elaboração Própria; 2019.

\subsection{Conclusões}

Deste modo, como primeira conclusão, deve ser destacado o seguinte fato: se por um lado as distribuidoras avaliadas possuíam o selo Empresa Pró-Ética, o que representaria a total conformidade dos seus respectivos Programas de Integridade à legislação, já que este é o grau mais alto de certificação em compliance de integridade; por outro, frente às inconsistências encontradas, restou claro que os critérios utilizados pela Controladoria Geral da União parecem não ser suficientes para essas empresas. Essa constatação, por sua via, parece se originar em um fato óbvio, porém fundamental: foram avaliadas por este trabalho duas distribuidoras de energia elétrica. Assim, trata-se de empresas que possuem todo um arcabouço regulatório específico, que deve ser verificado de uma forma diferenciada e meticulosa, em razão das particularidades atinentes à atividade econômica que desenvolvem e às minúcias do próprio setor elétrico. 
Deste modo e como consequência, conclui-se adicionalmente que para uma avaliação efetiva e eficaz dos Programas de Integridade implementados pelas distribuidoras de energia elétrica, não caberia apenas a utilização dos critérios comuns, elencados ordinariamente pela Lei Anticorrupção Brasileira e pela CGU. Como já dito, e exatamente por pertencerem ao setor elétrico, as empresas avaliadas, assim como toda e qualquer distribuidora, geradora ou transmissora de energia elétrica, deveriam ser submetidas a uma avaliação mais estruturada e voltada principalmente aos aspectos de conformidade regulatória. Referida avaliação conteria, nesse diapasão, critérios adicionais que dissessem respeito, principalmente, aos pontos regulatórios próprios do setor elétrico e de cada uma das respectivas atividades econômicas acima citadas, a ele pertencentes.

Aventa-se, inclusive, como contribuição para estudos futuros, a identificação de critérios adicionais para avaliação dos Programas de Integridade das empresas pertencentes ao setor elétrico, criando-se um programa de compliance específico para as distribuidoras. Para tanto, seria recomendável o aprofundamento de estudos sobre os aspectos regulatórios desse segmento, buscando compatibilizar medidas de mitigação de riscos de integridade a cada uma das respectivas obrigações regulatórias.

Como conclusão final, entende-se que a principal contribuição deste trabalho foi, portanto, a constatação de que os critérios utilizados pela Controladoria Geral da União para avaliação dos Programas de Integridade das empresas, com base somente nas suas próprias orientações normativas e na letra fria da Lei Anticorrupção Brasileira, não servem de parâmetro irrepreensível para medição da conformidade em relação às distribuidoras de energia elétrica. Sendo assim, deveriam ser adotados novos e específicos critérios para avaliação dessas empresas, cujas premissas seriam baseadas no arcabouço regulatório inerente à sua respectiva atividade econômica. A adoção desses novos critérios, por sua vez, auxiliaria as distribuidoras a manter-se sempre em compliance, tanto em relação às suas obrigações regulatórias quanto em relação às suas obrigações de integridade, através da instituição de métricas de conformidade e de políticas de monitoramento. 
Esse comportamento, destarte, traria uma série de benefícios a ele atrelados, como a mitigação do risco de autuações administrativas e da aplicação de sanções pecuniárias, previstas tanto na norma regulatória quanto na norma de integridade. Isso tudo, por fim, contribuiria não só para conceder uma maior segurança técnica e jurídica às empresas do setor, mas também e principalmente, para consolidar sua posição de protagonismo em questões de integridade, merecidamente erigida. 


\section{REFERÊNCIAS BIBLIOGRÁFICAS}

ABRADEE. Associação Brasileira de Distribuidores de Energia Elétrica. A Distribuição de Energia. Conforme disponível na página http://www.abradee.com.br/setor-de-distribuicao/a-distribuicao-de-energia/, acessada em 24/05/2019.

ABRADEE. Associação Brasileira de Distribuidores de Energia Elétrica. Distribuidoras e Origem de Capital. Conforme disponível na página http://www.abradee.org.br/setor-de- distribuicao/distribuidoras-e-origem-decapital/, acessada em 24/05/2019.

ABRADEE. Associação Brasileira das Distribuidoras de Energia Elétrica. Carga de energia do sistema interligado do Brasil avança 1,8\% em abril, diz ONS. Conforme disponível na página http://www.abradee.org.br/carga-de-energia-dosistema-interligado-do-brasil-avanca-18-em-abril-diz-ons/, acessada em 25/05/2019.

ALEXANDER, Cindy R. Trends in the Use of Non-Prosecution, Deferred Prosecution, and Plea Agreements in the Settlement of Alleged Corporate Criminal Wrongdoing. Conforme disponível na página https://masonlec.org/searle-civil-justice-institute/use-non-prosecutionagreements-deferred-prosecution-agreements/, acessada em 20/05/2019.

ANDRADE, Zilda Aparecida Freitas de. Gestão da ética nas organizações: possibilidades aos profissionais de relações públicas e comunicação organizacional. 2010. Tese (Doutorado) - Escola de Comunicações e Artes ECA, Universidade de São Paulo, 2010.

ANDRADE NETO, Eduardo Belém. Voto de Cabresto: História e Práticas Atuais. Conforme disponível na página https://www.politize.com.br/voto-decabresto/, acessada em 20/05/2018. 
ANEEL. Agência Nacional de Energia Elétrica. Página Principal. 2019. Conforme disponível na página http://www.aneel.gov.br/, acessada em 25/05/2018.

ANEEL. Agência Nacional de Energia Elétrica. Revisão Tarifária Periódica. Conforme disponível na página http://www2.aneel.gov.br/area.cfm?idArea=182, acessada em 25/05/2018.

ANTAGONISTA. Suíça, China e Bahamas. Conforme disponível na página https://www.oantagonista.com/brasil/suica-china-e-bahamas/, acessada em 16/05/2019.

ANTAGONISTA. Lava Jato apura propina na Transpetro. Conforme disponível na página https://www.oantagonista.com/brasil/lava-jato-apura-propina-natranspetro/, acessada em 16/05/2019.

ARAÚJO, André Motta. O caso Lockheed ou como os EUA lideram com a corrupção. 2015. Conforme disponível na página https://jornalggn.com.br/artigos/o-caso-lockheed-ou-como-os-eua-lideram-coma-corrupcao-por-motta-araujo/, acessada e, 15/05/2019.

ARISTÓTELES. Da Geração e Corrupção. Obras Completas. Editora Edipro. 2016. 1. Edição.

ARISTÓTELES. Ética e Nicômano. Conforme disponível na página https://cdn.culturagenial.com/arquivos/etica-a-nicomaco.pdf, acessada em $12 / 05 / 2019$.

ASSI, Marcos. Compliance: como implementar. - São Paulo: Trevisan Editora, 2018.

ASSI, Marcos. Gestão de Compliance e seus Desafios: como implementar controles internos, superar dificuldades e manter a eficiência dos negócios - São Paulo, Saint Paul Editora, 2013. 
ATTUCH, Leonardo. A Verdadeira História da Operação Satiagraha. Disponível na página https://www.brasil247.com/pt/247/brasil/55043/Averdadeira-hist \%C3\%B3ria-da-Opera\%C3\%A7\%C3\%A3o-Satiagraha.htm, acessada em 15/05/2019.

BANCO MUNDIAL, 2019. Disponível na página

https://www.worldbank.org/pt/country/brazil, acessada em 10/05/2019.

BBC BRASIL. Corrupção no Brasil tem origem no período colonial, diz historiadora. Conforme disponível na página https://www.bbc.com/portuguese/noticias/2012/11/121026 corrupcao origens mdb.shtml, acessada em 20/05/2019.

BEZERRA, Cloves. Ética na Escola. Conforme disponível na página https://www.academia.edu/6581849/\%C3\%89tica na Escola, acessada em 25/05/2019.

BEZERRA, Juliana. Era Vargas ou Nova República. Conforme disponível na página https://www.todamateria.com.br/brasil-republical, acessada em 15/05/2019.

BEZERRA, Juliana. Impeachment de Collor. Disponível na página https://www.todamateria.com.br/impeachment-de-collor/, acessada em 15/05/2019.

BOBBIO, Norberto; MATTEUCCI, Nicola; PASQUINO, Gianfranco. Dicionário de Política. Brasília. Editora UNB., 2009.

BRAGHINI, Aline Cristina. A importância do compliance e programa de integridade na atualidade. Conforme disponível na página https://www.conjur.com.br/2019-mar-23/aline-braghini-importancia-complianceprograma-integridade, acessada em 25/05/2019. 
CARREIRO, Isadora. A Cultura do Compliance no Setor Elétrico. Conforme disponível na página http://canalenergia.com.br/artigos/25990148/a-cultura-docompliance-no-setor-eletrico, acessada em 10/05/2019.

CARVALHO, Aloysio Castelo. As denúncias de corrupção no governo Vargas. Disponível na página http://observatoriodaimprensa.com.br/armazemliterario/ ed746 as denuncias de corrupcao no governo vargas/, acessada em 15/05/2019.

CARVALHO, André Castro. Manual de Compliance / coordenação André Castro Carvalho, Tiago Cripa Alvim, Rodrigo de Pinho Bertoccelli, Otavio Venturini. - Rio de Janeiro: Forense, 2019, p.36.

CARVALHOSA, Modesto; Considerações sobre a Lei Anticorrupção das Pessoas Jurídicas: Lei n. 12.846 de 2013 / Modesto Carvalhosa. São Paulo, Editora Revista dos Tribunais, 2015.

CAZZOLA, Franco. Della corruzione. Fisiologia e patologia di un sistema politico. Bologna: Società editrice il Milano, 1988, p. 12-14. (Tradução livre).

CEMIG. Companhia Energética de Minas Gerais. História da Eletricidade no Brasil. Conforme disponível na página http://www.cemig.com.br/ptbr/a cemig/Nossa Historia/Paginas/historia da eletricidade no brasil.aspx, acessada em 20/05/2019.

CGMSP. CONTROLADORIA GERAL DO MUNICÍPIO DE SÃO PAULO. Programa de Integridade. Conforme disponível na página https://www.prefeitura.sp.gov.br/cidade/secretarias/upload/controladoria geral/ Guia.pdf, acessada em 19/05/2019.

CGU. Controladoria Geral da União. Exposição de Motivos Interministerial n. 00011/2009 - CGU/MJ/AGU. Disponível em Http://www.planalto.gov.br/ccvil 03/projetos/EXPMOTIV/EMI/2010/11\%20\%20 CGU\%20MJ\%20AGU.HTM. Acessado em 10/mar/2018. 
CGU. Controladoria Geral da União. Conheça as Empresas Pró-Ética 2017. Disponível em http://www.cgu.gov.br/assuntos/etica-e-integridade/empresa-proetica. Acessado em 10/mar/2018.

CGU. Controladoria Geral da União. Programa de Integridade - Diretrizes para Empresas Privadas. Disponível em: https://www.cgu.gov.br/Publicacoes/etica-e-integridade/arquivos/programa-deintegridade-diretrizes-para-empresas-privadas.pdf. Acessado em 10/mar/2018.

CÍCERO, Marco Túlio. As Catilinárias - Coleção Obra-Prima de Cada Autor. Editora Amazon. 2019. Conforme disponível na página https://www.amazon.com.br/As-Catilin\%C3\%A1rias-Cole\%C3\%A7\%C3\%A3oObra-Prima-Autor/dp/B00I0EGQA6?tag=goog0ef20\&smid=A1ZZFT5FULY4LN\&ascsubtag=go 726685122542921375212425 94579893 pla-398033050251 c, acessada em 15/05/2019.

COIMBRA, Leila. Divisor de águas no setor elétrico, MP 579 trouxe impactos de R\$ 200 bi às tarifas. Conforme disponível na página http://www.agenciainfra.com/blog/divisor-de-aguas-no-setor-eletrico-mp-579trouxe-impactos-de-r-200-bi-as-tarifas/, acessada em 23/05/2019.

CORREAA, Maurício. O novo papel das distribuidoras. Conforme disponível na página https://www.paranoaenergia.com.br/opiniao-do-editor/2017/07/28/onovo-papel-das-distribuidoras/, acessada em 22/05/2019.

DAMODARAN, A. Avaliação de investimentos: Ferramentas e Técnicas para a Determinação do Valor de Qualquer Ativo. Rio de Janeiro: Qualitymark, 1999.

DARIE, Marina. O que Aconteceu no Escândalo do Mensalão? Conforme disponível na página https://www.politize.com.br/mensalao-o-que-aconteceu/, acessada em 15/05/2019. 
ELLIS, Matteson. Lista Geral de Red Flags de Corrupção de Terceiros. Conforme disponível na página http://fcpamericas.com/portuguese/lista-geralde-red-flags-de-corrupcao-de-terceiros/\#, acessada em 20/05/2019.

EPE. Empresa de Pesquisa Energética. EPE publica o Anuário Estatístico de Energia Elétrica 2018. Conforme disponível na página http://www.epe.gov.br/pt/imprensa/noticias/epe-publica-o-anuario-estatistico-deenergia-eletrica-2018, acessada em 25/05/2018.

ESTADO DE SÃO PAULO. Petrobrás é o segundo maior escândalo de corrupção do mundo, aponta Transparência Internacional. Conforme disponível na página https://politica.estadao.com.br/blogs/faustomacedo/petrobras-e-o-segundo-maior-escandalo-de-corrupcao-do-mundoaponta-transparencia-internacional/, acessada em 10/05/2019.

ESTADO DE SÃO PAULO. Inspiração estrangeira ajuda no combate à corrupção no Brasil? Conforme disponível na página https://economia.estadao.com.br/discute/inspiracao-estrangeira-ajuda-nocombate-a-corrupcao-no-brasil,278, acessada em 20/05/2019.

FAZZIO JUNIOR, Aldo. Corrupção Passiva: Introdução. Conforme disponível na página http://fazziojuridico.com.br/corrupcao-passiva-introducao/, acessado em 11/05/2019.

FERRAZ JUNIOR, Tercio Sampaio. Corrupção: ética ou política. Revista USP, n. 110, p. 15-28, 2017.

FILGUEIRAS, Fernando. A Tolerância à Corrupção no Brasil: uma antinomia entre as normas morais e a prática social. Opinião Pública, Campinas, v. 15, n. 02, p 386-421, nov. 2009.

FILGUEIRAS, Fernando. Corrupção, Democracia e Legitimidade. Belo Horizonte: UFMG, 2008, p. 55. 
FOLHA DE SÃO PAULO. Mais Empresas Adotam Práticas de Compliance. Conforme disponível na página http://estudio.folha.uol.com.br/petrobras/2017/06/1892322-mais-empresasadotam-praticas-de-compliance.shtml, acessada em 10/05/2019.

FOLHA DE SÃO PAULO. PF Cumpre Mandado em Empresas Ligadas a Paulo Roberto da Costa. Conforme disponível na página https://www1.folha.uol.com.br/poder/2014/08/1504228-pf-cumpre-mandadosem-empresas-ligadas-a-paulo-roberto-costa.shtml, acessado em 16/05/2019.

FREIRE, Flávio. Relatório da PF cita possível envolvimento de Lula em crimes. Conforme disponível na página https://oglobo.globo.com/brasil/relatorioda-pf-cita-possivel-envolvimento-de-lula-em-crimes-18725443, acessada em 16/05/2019.

FREIRE, Marcelo. Conheça dez histórias de corrupção durante a ditadura militar. Conforme disponível na página https://noticias.uol.com.br/politica/ultimas-noticias/2015/04/01/conheca-dezhistorias-de-corrupcao-durante-a-ditadura-militar.htm, acessada em 15/05/2019.

FREITAS, Vladimir Passos de. "Petrolão", o mais importante caso criminal da história do Brasil. Conforme disponível na página https://www.conjur.com.br/2015-mar-08/segunda-leitura-petrolao-importantecriminal-historia-brasil, acessada em 15/05/2019.

G1 BA. Malas que armazenavam R\$ 51 milhões em bunker atribuído a Geddel são entregues ao STF. Conforme disponível na página https://g1.globo.com/ba/bahia/noticia/malas-que-armazenavam-r-51-milhoesem-bunker-atribuido-a-geddel-sa o-entregues-ao-stf.ghtml, acessada em 16/05/2019.

G1 Brasília. Cândido Vaccarezza é preso em nova fase da Operação Lava Jato em São Paulo. Conforme disponível na página https://g1.globo.com/sao- 
paulo/noticia/vaccarezza-e-preso-em-nova-fase-da-operacao-lava-jato-em-saopaulo.ghtml, acessada em 16/05/2019.

G1 Brasília. Janot apresenta ao Supremo denúncia contra Temer por corrupção passiva. Conforme disponível na página https://g1.globo.com/politica/noticia/janot-apresenta-ao-supremo-denunciacontra-temer-por-corrupcao.ghtml, acessada em 16/05/2019.

G1 Brasília. Janot pede ao STF 83 inquéritos para investigar políticos citados por delatores. Conforme disponível na página https://g1.globo.com/politica/operacao-lava-jato/noticia/janot-pede-ao-stfinvestigacao-de-politicos-citados-na-delacao-da-odebrecht.ghtml, acessada em 16/05/2019.

G1 Economia. Veja o histórico da notas de crédito do Brasil. Disponível em https://g1.globo.com/economia/noticia/veja-historico-das-notas-de-credito-dobrasil.ghtml. Acessado em 10/mar/2018.

G1 Educação. Watergate e o impeachment de Nixon. Conforme disponível em http://educacao.globo.com/artigo/watergate-e-o-impeachment-de-nixon.html. Acessado em 15/05/2019.

G1 PR. 54a fase da Lava Jato é deflagrada, com mandados de busca e apreensão em Portugal. Conforme disponível na página https://g1.globo.com/pr/parana/noticia/2018/09/25/54a-fase-da-lava-jato-edeflagrada-com-mandado-de-busca-e-apreensao-em-portugal.ghtml, acessada em 16/05/2019.

G1 PR. Paulo Vieira de Souza, operador financeiro ligado ao PSDB, é preso na $60^{\mathrm{a}}$ fase da Lava Jato. Conforme disponível na página https://g1.globo.com/pr/parana/noticia/2019/02/19/pf-deflagra-60a-fase-daoperacao-lava-jato.ghtml, acessada em 16/05/2019. 
G1 PR. Tesoureiro do PT é preso em casa na nova etapa da Operação Lava Jato. Conforme disponível na página http://g1.globo.com/politica/operacao-lavajato/noticia/2015/04/tesoureiro-do-pt-e-preso-na-12-etapa-da-operacao-lavajato.html, acessada em 16/05/2019.

G1 Rio. Nestor Cerveró é preso pela Polícia Federal no aeroporto do Rio. Conforme disponível na página http://g1.globo.com/rio-dejaneiro/noticia/2015/01/nestor-cervero-e-preso-pela-policia-federal-noaeroporto-do-rio.html, acessada em 16/05/2019.

GOMES, João Paulo Pombeiro. O campo da energia elétrica no Brasil de 1880 a 2002. Conforme disponível na página http://app.ebape.fgv.br/comum/arq/295321.pdf, acessada em 22/05/2019.

GOVERNO DO ESTADO DO MATO GROSSO. Governo de Mato Grosso regulamenta Lei Anticorrupção. Conforme disponível na página http://www.mt.gov.br/-/3911892-governo-de-mato-grosso-regulamenta-leianticorrupcao, acessada em 19/05/2019.

HABIB, Sérgio. Brasil: quinhentos anos de corrupção. Enfoque sóciohistórico-jurídico-penal. Porto Alegre: Sergio Antonio Fabris, 1994, p. 147-148.

HEIDENHEIMMER, Johnston e Levine. Readings in comparative analysis on political corruption. New York: Holt, Rinegart and Winston, 1970. p. 3-6.

ILG, Jean. 10 escândalos de corrupção da ditadura militar, abafados pelas Forças Armadas. Disponível na página https://www.esquerdadiario.com.br/10escandalos-de-corrupcao-da-ditadura-militar-abafados-pelas-Forcas-Armadas, acessada em 15/05/2019.

JANUZZI, Antonio Cezar. Regulação da Qualidade da Energia Elétrica sob o Foco do Consumidor. Conforme disponível na página http://repositorio.unb.br/bitstream/10482/2712/1/Dissert Antonio\%20Jannuzzi.p df, acessada em 22/05/2019. 
KPMG. Pesquisa Maturidade do Compliance no Brasil. Conforme disponível na página http://www.amchamrio.com.br/srcreleases/compliance2.pdf, acessada em 25/05/2019.

MANDEL, Gabriel. Artigo: Para advogada, Lei Anticorrupção é divisor de águas. Conforme disponível na página https://www.conjur.com.br/2014-jan28/advogada-ve-lei-anticorrupcao-divisor-aguas-brasil, acessada em 20/05/2019, citando Adriana Dantas.

MAQUIAVEL, Nicolau. O Príncipe. Obra Completa, 2008. Editora Saraiva. São Paulo - pag. 1-218.

MARCEL, Dennys. Qual foi o primeiro caso de corrupção na história do Brasil? Conforme disponível na página https://ecoviagem.com.br/noticias/curiosidades/historia/qual-foi-o-primeiro-casode-corrupcao-na-historia-do-brasil--18807.asp, acessada em 20/05/2019.

MENDES, Francisco Schertel Compliance: conconrrência e combate à corrupção/ Francisco Schertel Mendes, Vinicius Marques de Carvalho. --São Paulo: Trevisan Editora, 2017, p.34.

MIRA, Renan Jorge Oliveira. Sociedades anônimas "off-shore" uruguaias e a lavagem de dinheiro. Conforme disponível na página https://jus.com.br/artigos/11520/sociedades-anonimas-off-shore-uruguaias-e-alavagem-de-dinheiro, acessada em 18/05/2019.

MONTEIRO, Raphael. Como a corrupção acrescenta riscos e rouba parte dos seus lucros. Conforme disponível na página https://www.investidorinternacional.com/2016/01/17/nao-invista-em-paisescorruptos/, acessada em 15/05/2019. 
MPF. Ministério Público Federal. Grandes casos. Conforme disponível na página http://www.mpf.mp.br/grandes-casos/caso-lava-jato/atuacao-na-1ainstancia/parana/linha-do-tempo, acessada em 10/05/2019.

MPF. Ministério Público Federal. Escândalo da Mandioca. Disponível na página http://www.mpf.mp.br/regiao5/atuacao/memoria-e-acao/escandalo-damandioca, acessada em 15/05/2019.

NAÇÕES UNIDAS BRASIL. Pacto Global - PNUD. Disponível na página https://nacoesunidas.org/onu-no-brasil/pacto-globalpnud/, acessada em 19/11/2019.

NEGRÃO, Célia Regina P. Lima. Compliance, Controles Internos e Riscos: a importância da área de gestão de pessoas. Brasília, Editora Senac, 2014.

NEVES, Edmo Colnaghi. Compliance empresarial: o tom da liderança: estrutura e benefícios do programa/Edmo Colnaghi Neves. --São Paulo: Trevisan Editora, 2018, p.18.

OCDE. Organisation for Economic Co-Operation and Development. Guidelines for Multinational Enterprises. 2011, p.19-20. Disponível em HTTP://dx.doi.org/10.1787/9789264115415-en.

OLIVEIRA, Fabrício Ferreira. Crimes contra a Administração Pública: diferença entre concussão e corrupção passiva. Conforme disponível na página https://jus.com.br/artigos/39764/crimes-contra-a-administracao-publicadiferenca-entre-concussao-e-corrupcao-passiva, acessada em 20/05/2019.

PIETH, Mark. Introduction. In : Pieth, Mark; Low, Lucinda A.; Cullen, Peter J. The OCDE Convention On Bribery: a commentary. Cambridge: Cambridge University Press, 2007, p.6-7. 
PRAÇA, Sérgio. O Brasil é mais corrupto do que a China? Conforme disponível na página https://exame.abril.com.br/blog/sergio-praca/o-brasil-emais-corrupto-do-que-a-chinal, acessada em 22/05/2019.

PWC. PriceWaterhouseCoopers. FCPA, UK Bribery Act e Lei 12.846/13. Avanços e desafios. Conforme disponível na página http://www.amchamrio.com.br/srcreleases/juliana breno.pdf, acessada em 21/05/2019.

RAMALHO, Willian. Ser e estar em compliance. Conforme disponível na página https://www.mega.com.br/blog/ser-e-estar-em-compliance-7591/, acessada em 25/05/2019.

RANGEL, Rodrigo. Lava Jato deflagra nova operação e decreta prisão de João Santana. Conforme disponível na página https://web.archive.org/web/20160223103822/http://veja.abril.com.br/noticia/bra sil/pf-deflagra-23-fase-da-operacao-lava-jato, acessada em 16/05/2019.

REZENDE, Joffre Marcondes. Epidemia, endemia, pandemia. Epidemiologia. Disponível na página https://www.revistas.ufg.br/iptsp/article/download/17199/10371/, acessada em 10/05/19.

RICUPERO, Rubens. 0 mundo após o 11 de setembro: a perda da inocência. Conforme disponível na página http://www.scielo.br/scielo.php?script=sci arttext\&pid=S010320702003000200002, acessada em 22/05/2019.

ROSENBERG, Luiz Paulo; Bistafa, Rafael; Cunha Filho, Alexandre Jorge Carneiro da. 48 Visões sobre a Corrupção. São Paulo, Quartier Latin, 2016.

SANTOS, Claudia C.; BIDINO, Claudio; MELO, Débora T. A corrupção: reflexões (a partir da lei, da doutrina e da jurisprudência) sobre o seu 
regime jurídico-criminal em expansão no Brasil e em Portugal. Coimbra Editora. 2009.

SARDINHA, Edson. Entenda o caso: o que foi a Operação Sanguessuga. Disponível na página https://congressoemfoco.uol.com.br/especial/noticias/entenda-o-caso-o-que-foia-operacao-sanguessuga/, acessada em 15/05/2019.

SASAKI, Daniel Leb. “Caso Panair” completa 50 anos, ainda sem desfecho judicial. 2015. Disponível na página https://epocanegocios.globo.com/Informacao/Dilemas/noticia/2015/02/casopanair-completa-50-anos-ainda-sem-desfecho-judicial.html, acessada em 15/05/2019.

SENADO FEDERAL. Projeto aprovado na CCJ obriga partido político a seguir programa de integridade. Conforme disponível na página https://www12.senado.leg.br/noticias/materias/2019/03/20/projeto-aprovado-naccj-obriga-partido-politico-a-seguir-programa-de-integridade, acessada em 19/05/2019.

SIGNIFICADOS. Conceito de Corrupção. Conforme disponível na página https://www.significados.com.br/corrupcao/, acessado em 11/05/2019.

SILVA, Fernanda Cintra Laureano. Ética: conduta ideal e conduta real. Conforme disponível na página https://www.direitonet.com.br/artigos/perfil/exibir/133705/Fernanda-CintraLauriano-Silva, acessada em 25/05/2019.

SILVEIRA, Renato de Melo Jorge. Compliance, Direito Penal e Lei Anticorrupção/Renato de Melo Jorge Silveira, Eduardo Saad-Diniz. São Paulo, Saraiva, 2015.

SOARES, Patricia Diniz. BNDES exige compliance para concessão de financiamento. Conforme disponível na página 
http://www.portaldelicitacao.com.br/site/artigos/bndes-exige-compliance-psaraconcessao-de-financiamentol, acessada em 25/05/2019.

TALON, Evinis. Concussão x corrupção passiva. Conforme disponível na página http://evinistalon.com/concussao-x-corrupcao-passival, acessada em 21/05/2019.

TAVARES, M. C. Vinte anos de política fiscal no Brasil: dos fundamentos do novo regime à Lei de Responsabilidade Fiscal. Revista de Economia \& Relações Internacionais. v.4. n.7 jul 2005.

TORRES, Fernando. Valor de mercado da Petrobras cai abaixo de R $\$ \mathbf{1 0 0}$ bilhões. Conforme disponível na página https://www.valor.com.br/empresas/4238956/valor-de-mercado-da-petrobrascai-abaixo-de-r-100-bilhoes, acessada em 18/05/2019.

TRANSPAREANCIA INTERNACIONAL. Transparência Internacional. Conforme disponível na página https://transparenciainternacional.org.br/home, acessada em 10/05/2019.

TUCCl, José Rogério Cruz e. Precedente judicial como fonte de direito. São Paulo: RT, 2004.

UNITED STATES DEPARTMENT OF JUSTICE, 2018. Overview about Foreign Corrupt Practices Act - FCPA. Disponível em https://www.justice.gov/criminalfraud/foreign-corrupt-practices-act. Acessado em 11/mar/2018.

UNITED KINGDOM GOVERNMENT, 2018. Legislation Bribery Act, 2010. Disponível em https://www.legislation.gov.uk/ukpga/2010/23/contents. Acessado em $11 / \mathrm{mar} / 2018$.

VALLS, Álvaro L. M. O que é ética. São Paulo: Brasiliense, 1994 (Coleção Primeiros Passos), p.07. 
VERÍSSIMO, Carla. Compliance: incentivo à adoção de medidas anticorrupção. São Paulo: Saraiva, 2017.

VIEIRA, André. Lava-Jato deflagra 14 fase e Prende Executivos da Odebrecht. Conforme disponível na página https://www.valor.com.br/politica/4100752/lava-jato-deflagra-14, acessada em 16/05/2019.

VIRTUOUS. Tecnologia da Informação, 2009-2019. Conforme disponível na página http://www.sohistoria.com.br/biografias/hammurabi/, acessada e, 15/05/2019.

WIKIPEDIA. Operação Lava Jato. Conforme disponível na página https://pt.wikipedia.org/wiki/Opera\%C3\%A7\%C3\%A3o Lava Jato, acessada em 16/05/2019. 


\section{ANEXO 1 - QUESTIONÁRIO DE AVALIAÇÃO EMPRESA PRÓ-ÉTICA ELABORADO PELA CONTROLADORIA GERAL DA UNIÃO (CGU)}

\section{QUESTIONÁRIO DE AVALIAÇÃO}

\section{Comprometimento da Alta Direção e Compromisso com a Ética}

1. De que maneira a alta direção demonstra seu comprometimento com a ética e a integridade (incluindo a prevenção e o combate à corrupção e à fraude em licitações e contratos), envolvendo-se nas ações relacionadas a esse tema?

2. De que maneira a alta direção supervisiona a implementação e manutenção do programa de integridade (aplicação das normas, realização das atividades de treinamento, comunicação, verificação de terceiros, investigações de denúncias, etc)?

3. A empresa possui uma área/ pessoa específica responsável pela implementação e manutenção do programa de integridade? Como se organiza esta área e de que tipo de estrutura dispõe (recursos humanos, espaço, materiais, etc)? Caso haja mais de uma estrutura responsável por atividades ligadas ao programa (como uma área gerencial e um comitê) favor explicar separadamente.

4. Qual valor aproximado foi alocado pela empresa para a implementação e manutenção do programa de integridade nos últimos três anos?

5. Quais medidas são adotadas para garantir que a área/ pessoa responsável pela implementação e manutenção do programa de integridade tenha a independência necessária ao exercício de suas atribuições? A quem esta área/pessoa se reporta?

6. A empresa participa de ações coletivas voltadas à prevenção e ao combate à corrupção por meio de associações com outras empresas e entidades? Quais?

\section{Políticas e Procedimentos}

\section{II.1 Padrões de Conduta}


1. A empresa possui um documento que estabeleça as diretrizes para seus funcionários e dirigentes (geralmente conhecido como Código de Ética ou Código de Conduta)? Em caso afirmativo, explique os principais conteúdos abordados.

2. Os seguintes temas estão contemplados nesse documento? Em caso afirmativo, explique e indique o(s) dispositivo(s).

a. Declaração de valores e princípios relacionados com a ética e a integridade.

b. Definição das condutas permitidas e proibidas.

c. Proibição de práticas de fraude e corrupção, inclusive transnacional, quando aplicável. d. Previsão de medidas disciplinares para o descumprimento de normas éticas, inclusive do Código de Ética/Conduta. 3. Este documento, ou documento equivalente, possui também diretrizes aplicáveis a fornecedores, prestadores de serviços, agentes intermediários, dentre outros? Em caso afirmativo, explique e indique o(s) dispositivo(s).

\section{II.2 Política Anticorrupção}

4. A empresa possui políticas específicas para prevenção e combate à corrupção (política anticorrupção)? Em caso afirmativo, explique os principais conteúdos abordados.

5. Esta política (ou outras normas que tratem de prevenção e combate à corrupção e às fraudes) aborda os seguintes temas relativos ao relacionamento com o setor público? Em caso afirmativo, indique o dispositivo.

a. Regras e orientações voltadas a questões regulatórias, obtenção de licenças, autorizações ou permissões;

b. Procedimento de realização de reuniões com servidores ou empregados públicos. Especificar se a empresa possui controle da agenda de reuniões com agentes públicos;

c. Proibição clara e irrestrita de atos de corrupção;

d. Proibição clara e irrestrita de atos de corrupção transnacional;

e. Regras e orientações sobre a atuação de diretores, funcionários e colaboradores que tenham parentesco com agentes públicos com poder decisório no âmbito de negócios e operações com órgãos e entidades do governo; 
f. Regras e orientações sobre a contratação permanente e para prestação de serviços de atuais e ex servidores ou empregados públicos;

g. Regras e orientações sobre o oferecimento de presentes, brindes, refeições, entretenimento, viagem, hospedagem e quaisquer outros benefícios ou vantagens, econômicas ou não, a servidores ou empregados públicos. Especificar, ainda, se a empresa possui um controle dos presentes, brindes e hospitalidade oferecidos.

6. Que tipos de regras e orientações voltadas à participação em procedimentos licitatórios e acompanhamento de contratos administrativos a empresa possui? Estas regras incluem medidas de controle voltadas para prevenir fraudes e ilícitos? Explique também a forma de aplicação e de controle da conformidade com estas medidas.

\section{II.3 Avaliação de Terceiros}

7. Existem regras sobre a realização de verificações previamente à contratação de fornecedores e prestadores de serviços, objetivando identificar histórico de envolvimento com corrupção ou outros tipos de condutas ilegais ou antiéticas? Explique o conteúdo e a forma de aplicação.

8. Existem regras sobre a realização de verificações previamente à contratação de agentes intermediários objetivando identificar histórico de envolvimento com corrupção ou outros tipos de condutas ilegais ou antiéticas? Explique o conteúdo e a forma de aplicação.

9. Houve casos recentes de possíveis fornecedores, prestadores de serviços e/ou agentes intermediários que deixaram de ser contratados ou foram dispensados devido a informações reveladas por estes procedimentos de verificação?

10. A empresa prevê em seus contratos com fornecedores, prestadores de serviços e agentes intermediários a obrigatoriedade do cumprimento de normas éticas e a vedação de práticas de fraude e corrupção? Há, ainda, a previsão de aplicação de penalidades e/ou de rescisão contratual em caso de descumprimento destas normas? 
11. Como é feito o acompanhamento, durante a execução do contrato, da observância desses valores e princípios de integridade por parte de seus contratados?

12. Existem regras sobre a realização de verificações previamente a fusões, aquisições ou outras operações societárias, objetivando identificar histórico de envolvimento com corrupção ou outros tipos de condutas ilegais ou antiéticas? Explique o conteúdo e a forma de aplicação. Houve casos recentes de aplicação destes procedimentos? Explique.

\section{4 Controles Interno e Externo}

13. De que maneira a empresa busca garantir que seus registros contábeis, relatórios e demonstrações financeiras sejam completos e precisos? Explique as normas/medidas de controle interno adotadas especificamente para este fim.

14. A área responsável pelo programa de integridade (ou outra área, neste caso especificar qual) possui a atribuição de identificar despesas ou receitas específicas com perfil de risco mais elevado e atuar para certificar-se de sua natureza e correto registro? Possui atribuição para identificar e investigar mudanças nos padrões de receita ou despesa que possam indicar risco de corrupção ou violação às normas de integridade da empresa?

15. A empresa possui uma área, departamento estruturado ou pessoa responsável pela função de auditoria interna? Caso positivo, descreva brevemente suas principais funções.

16. A empresa submete-se a auditoria externa contábil ou de aspectos ligados ao programa de integridade? Em caso positivo, informar:

a. se a auditoria externa é realizada por imposição legal ou de forma voluntária pela empresa.

b. a periodicidade de tais auditorias.

c. se possui regras em relação à obrigatoriedade de alternância da empresa responsável por sua auditoria externa. d. se possui regras em relação à proibição de que a empresa contratada para a auditoria externa seja contratada também para outros serviços, como contabilidade, consultoria na área de administração, etc. 
17. Há interface da área responsável pelo programa de integridade com o departamento de Gestão de Pessoas (ou Recursos Humanos) para incorporar elementos de ética, integridade em processos de seleção e novas contratações da empresa e outros processos relacionados à gestão de pessoas?

\section{Comunicação e Treinamento}

\section{III.1 Comunicação}

18. Qual a estratégia utilizada para divulgar junto aos funcionários e dirigentes os temas de ética e temas relacionados ao programa de integridade? Que tipos de comunicações sobre esses temas são utilizados e com que frequência? (Ex: informativos, boletins internos, emails, circulares, cartazes, vídeos, etc). Como a empresa adapta as comunicações e a linguagem aos diferentes públicos? Como é divulgado o Código de Ética/conduta ou documento equivalente?

19. Como a empresa garante que todos os funcionários, de diferentes níveis hierárquicos, e dirigentes tenham acesso às normas relacionadas ao programa de integridade, inclusive suas eventuais atualizações ou modificações?

20. Como a empresa possibilita que intermediários, fornecedores, prestadores de serviços tenham acesso às normas relacionadas ao Programa de Integridade, inclusive suas eventuais atualizações ou modificações?

21. De que maneira é feita a divulgação ao público externo do compromisso com a ética e a integridade e o não-compactuamento com a corrupção?

\section{III.2 Treinamento}

22. Qual(is) a(s) unidade(s) responsável(eis) pelo planejamento da capacitação sobre temas de ética e integridade?

23. Como são realizados os eventos de capacitação? Explique que tipo de metodologia(s) é(são) utilizado(s) nos treinamentos, qual a periodicidade com que são aplicados e qual a estratégia utilizada para incentivar a participação dos funcionários nos treinamentos e/ou para aplicar medidas disciplinares aos que faltarem sem justificativa. Liste, ainda, as capacitações realizadas nos últimos doze meses em temas relacionados ao programa de integridade. 
24. Qual(is) mecanismos são utilizados para assegurar que todos os funcionários, dirigentes sejam alcançados pelas capacitações de conteúdo de interesse geral e que as capacitações específicas alcancem o público de interesse para cada tema?

25. A empresa utiliza algum mecanismo ou estratégia para verificar a retenção e compreensão das informações por parte dos funcionários treinados ou os efeitos dos treinamentos sobre seu desempenho profissional?

26. Qual a política de capacitação e treinamento para novos funcionários?

27. Qual(is) mecanismos são utilizados para assegurar que os agentes intermediários sejam alcançados pelas capacitações de conteúdo de interesse geral (código de ética, princípios e valores, etc) e pelas capacitações voltadas especificamente para esse setor?

\section{Canais de Denúncia e Remediação}

28. De que forma a empresa possibilita a realização de denúncias de irregularidades por parte de funcionários, intermediários, fornecedores, prestadores de serviço e público externo? Descrever todos os canais existentes para realização de denúncias.

29. A empresa incentiva a realização de denúncias de irregularidades por parte de seus funcionários, intermediários, fornecedores, prestadores de serviço e público externo? Especificar.

30. Há oferecimento de proteção aos denunciantes como, por exemplo, possibilidade de apresentação de denúncia anônima ou proibição de retaliação a funcionários que realizam denúncias de boa-fé?

31. Como se dá o processo de recebimento, tratamento e apuração de denúncias? Que tipo de estrutura é disponibilizada para a realização dessas funções? Qual o setor (ou pessoa) responsável por investigar as suspeitas e as denúncias de irregularidades ligadas à ética e à violação do programa de integridade?

32. Quais os procedimentos utilizados para assegurar a pronta interrupção de irregularidades ou infrações detectadas e a tempestiva remediação da situação? 33. Quais as medidas disciplinares estabelecidas para aqueles que cometerem irregularidades relacionadas à ética e ao programa de integridade e como elas 
são aplicadas? Tais medidas alcançam a alta direção? Qual o setor (ou pessoa) responsável por aplicar as penalidades?

34. Como são tratadas as denúncias de irregularidades praticadas por intermediários, fornecedores e prestadores de serviços?

35. Existe alguma norma/procedimento em relação ao encaminhamento de denúncias sobre eventuais atos de fraude, improbidade e corrupção às autoridades competentes?

\section{Análise de Risco e Monitoramento}

36. Quais os mecanismos utilizados para avaliar os riscos de fraude e de corrupção aos quais a empresa está submetida, quem são os responsáveis por realizar essa avalição (é realizada internamente ou por alguma consultoria externa) e com qual periodicidade ela é feita?

37. A avaliação de risco foi considerada quando da elaboração do programa de integridade? Ela é considerada para a atualização e aperfeiçoamento do programa de integridade?

38. Quais os mecanismos utilizados para monitorar a aplicação e a efetividade do programa de integridade e quem são os responsáveis por realizar essa atividade?

39. O programa de integridade já foi alterado ou aperfeiçoado (no que diz respeito à prevenção e combate à fraude e corrupção) como resultado de uma atividade de monitoramento? Caso positivo, a mudança contribuiu para o aprimoramento da efetividade na prevenção, detecção e combate à ocorrência de irregularidades? Especifique.

\section{Transparência e Responsabilidade no Financiamento Político e Social}

\section{VI.1 Transparência}

40. Quais são as medidas de transparência adotadas pela empresa para o público interno e público externo? 
41. As seguintes informações são divulgadas pela empresa em seu sítio eletrônico, redes sociais ou por qualquer outro meio que garanta ampla divulgação e acesso ao público externo:

a. identificação de seus proprietários ou principais acionistas;

b. identificação e a função de seus principais executivos e dirigentes;

c. suas demonstrações financeiras;

d. informações sobre contratos firmados com a Administração Pública;

\section{VI.2 Responsabilidade no Financiamento Político e Social}

42. Quais as políticas adotadas em relação ao financiamento de partidos políticos e candidatos em campanhas eleitorais? Informar se existem normas estabelecendo limites máximos para doações, vedação para doações a candidatos com o histórico de corrupção, declaração à Justiça Eleitoral de todas as doações efetuadas, divulgação em seu sítio eletrônico das doações feitas a partidos políticos e candidatos.

43. A empresa recomenda as suas subcontratadas e outros parceiros de negócio a adoção da mesma política de financiamento político?

44. Quais as políticas adotadas em relação à realização de doações filantrópicas? A empresa realiza algum tipo de verificação prévia de possível histórico de corrupção ou fraude nas instituições a serem beneficiadas? A empresa realiza algum monitoramento para certificarse da correta aplicação do valor da doação efetuada? As doações realizadas são divulgadas em seu sítio eletrônico ou redes sociais ou por algum outro meio?

45. Quais as políticas adotadas em relação à realização de patrocínios, sobretudo aqueles realizados com base em leis de incentivo fiscal à cultura e ao esporte? A empresa realiza algum tipo de verificação para identificar possível histórico de envolvimento com corrupção ou fraude, por parte das instituições a serem beneficiadas? A empresa realiza algum monitoramento para certificar-se da correta aplicação do valor do patrocínio? Os patrocínios realizados são divulgados em seu sítio eletrônico ou redes sociais? Como é feito o controle contábil desses patrocínios? 


\section{ANEXO 2 \\ QUESTIONÁRIO PADRÃO SOBRE O PROGRAMA DE INTEGRIDADE ENVIADO PARA AS DISTRIBUIDORAS DE ENERGIA ELÉTRICA PESQUISADAS}

QUESTIONÁRIO

\section{Confidencial}

1) Existe algum programa de compliance ou de integridade implementado na empresa? Desde quando?

2) A empresa possui algum Código de Ética? Se possível anexar a esta pesquisa.

3) Como foi o processo de decisão para implementar o programa de integridade?

Qual a motivação da empresa? Se possível, anexar exposição de motivos.

4) Como funciona a estrutura de compliance da empresa (recursos, departamentos, reporte, número de funcionários, abrangência)? Se possível, anexar esquema de estrutura, fluxograma ou política interna.

5) Quais as políticas e procedimentos internos para divulgação do programa de integridade na empresa? Quais são? Se possível, anexar política interna.

6) Como a empresa lida com eventuais conflitos decorrentes do programa de integridade de outras empresas terceiras com que ela se relaciona, ou seja, quando deve ser declarado estar em conformidade com o programa de compliance de outra empresa em detrimento do seu próprio?

7) Existe alguma política de compliance para fornecedores? Existe análise reputacional de fornecedores? De que tipo? Se possível, anexar esquema de estrutura, fluxograma ou política interna.

8) Quais são os mecanismos de controles internos da empresa para atendimento ao programa de integridade? Preventivo e detectivo. Se possível, anexar esquema de estrutura, fluxograma ou política interna. 
9) Como é feito o monitoramento interno e externo do programa de integridade da empresa? Se possível, anexar esquema de estrutura, fluxograma ou política interna.

10) Na sua opinião, existe algum tipo de ponto que não foi e deveria ser abordado pelo programa de integridade da empresa?

11) Existe alguma política de compliance regulatório na empresa? Quais são? Se possível, anexar política interna.

12) Existe algum normativo de compliance da ANEEL? Se sim, a empresa o segue?

13) Em sua opinião, quais os principais riscos regulatórios a que a empresa está sujeita, que poderiam dar ensejo a uma situação de "não compliance" ou "nãoconformidade"?

14) Existem monitoramentos de compliance específicos para o setor elétrico, que tenham sido implementados pela empresa?

15) Existe algum tipo de monitoramento específico do setor elétrico que vc reputa importante ou que deveria ser considerado para inclusão no programa de integridade da empresa? 


\section{ANEXO 3 \\ QUESTIONÁRIO SOBRE O PROGRAMA DE INTEGRIDADE RESPONDIDO PELA PRIMEIRA DISTRIBUIDORA AVALIADA}

1) Existe algum programa de compliance ou de integridade implementado na empresa? Desde quando?

Sim. Desde 2014.

2) A empresa possui algum Código de Ética? Se possível anexar a esta pesquisa.

Sim. Disponível no site da empresa.

3) Como foi o processo de decisão para implementar o programa de integridade? Qual a motivação da empresa? Se possível, anexar exposição de motivos.

A empresa possui ADR Nível III negociadas na Bolsa de Nova York e ações negociadas no Novo Mercado da B3, os mais elevados níveis de governança corporativa do mercado de capitais dos EUA e do Brasil. Em linha com as melhores práticas de mercado, a empresa possui um Programa de Integridade e Compliance, que estabelece para todos os seus colaboradores os valores, princípios, padrões e normas de comportamento da organização e norteando a interação com agentes públicos. O Programa de Integridade e Compliance da empresa tem como um dos seus pilares a Política Anticorrupção do Grupo, lançada em 2014, e o Sistema de Gestão e Desenvolvimento do Código de Ética, revisitado em 2016. Além disso, atuação ética e íntegra tem transcendido a questão moral e se tornado um diferencial de negócios, com empresas optando por firmar contratos e fazer negócios com empresas que possuem mecanismos bem estabelecidos de compliance e ética. Assim como a empresa, fornecedores, clientes e parceiros têm questionado o nível de profundidade do Programa de Integridade da organização para o fechamento de novos negócios e parcerias. 
4) Como funciona a estrutura de compliance da empresa (recursos, departamentos, reporte, número de funcionários, abrangência)? Se possível, anexar esquema de estrutura, fluxograma ou política interna.

Uma Gerência de Riscos, Ética e Compliance com 5 profissionais, com => Reporte para o Head de Auditoria, Riscos e Compliance $=>$ Reporte para 0 Conselho de Administração. Abrangência => Todas as empresas do Grupo ao qual a empresa pertence.

5) Quais as políticas e procedimentos internos para divulgação do programa de integridade na empresa? Quais são? Se possível, anexar política interna.

Temos uma série de políticas e procedimentos internos relacionado ao tema que são suportados por nossos princípios e valores, conforme segue: Código de Conduta Ética. Comitê de Ética. Sistema de Gestão e Desenvolvimento da Ética (SDGE). Comissão de Processamento de Denúncias (CPD). Política Anticorrupção. Política de Patrocínios e Doações. Política de Brindes, Presentes e Hospitalidades. Sistema de registro dos encontros e reuniões com poder público. Há processo de treinamento constante de todos os colaboradores e fornecedores e monitoramento/investigação de eventuais transgressões.

6) Como a empresa lida com eventuais conflitos decorrentes do programa de integridade de outras empresas terceiras com que ela se relaciona, ou seja, quando deve ser declarado estar em conformidade com o programa de compliance de outra empresa em detrimento do seu próprio?

É realizada análise detalhada e comparativa dos requisitos para tomada de decisão. Na grande maioria dos casos verifica-se alinhamento das boas práticas e o consenso entre as partes.

7) Existe alguma política de compliance para fornecedores? Existe análise reputacional de fornecedores? De que tipo? Se possível, anexar esquema de estrutura, fluxograma ou política interna. 
Não temos uma específica para fornecedores. Porém, os requisitos estão de forma ampla nas nossas políticas e são parte integrante dos contratos com os fornecedores. Temos um processo de Background Check aplicados aos fornecedores classificados como sensíveis.

8) Quais são os mecanismos de controles internos da empresa para atendimento ao programa de integridade? Preventivo e detectivo. Se possível, anexar esquema de estrutura, fluxograma ou política interna.

Basicamente: Treinamentos; monitoramentos e canal de denúncia externo.

9) Como é feito o monitoramento interno e externo do programa de integridade da empresa? Se possível, anexar esquema de estrutura, fluxograma ou política interna.

Por meio de indicadores de auditoria contínua e canal de denúncias.

10) Na sua opinião, existe algum tipo de ponto que não foi e deveria ser abordado pelo programa de integridade da empresa?

Estamos em fase de ampliação do programa, identificando outras leis e regulamentos (internos e externos) de maior impacto para efeito de monitoramento e auto avaliação constante.

11) Existe alguma política de compliance regulatório na empresa? Quais são? Se possível, anexar política interna.

Ainda não temos uma política específica. Contudo, já temos 5 macro processos regulatórios da área de distribuição mapeados com controles avaliados periodicamente.

12) Existe algum normativo de compliance da ANEEL? Se sim, a empresa o segue? 
Existe um normativo estabelecendo níveis e práticas de governança requeridos, onde cita-se a questão do Compliance. Sim, estamos aderentes a estes requisitos.

13) Em sua opinião, quais os principais riscos regulatórios a que a empresa está sujeita, que poderiam dar ensejo a uma situação de "não compliance" ou "nãoconformidade"?

É necessário estar atento e monitorar alterações ou criações de novos regulamentos. Por exemplo, temos agora a nova Lei geral de proteção de dados que as empresas brasileiras estão tratando. Também são inúmeros os requisitos da área fiscal e que estão em constante mudança, entre outros.

14) Existem monitoramentos de compliance específicos para o setor elétrico, que tenham sido implementados pela empresa?

Idem item 11.

15) Existe algum tipo de monitoramento específico do setor elétrico que vc reputa importante ou que deveria ser considerado para inclusão no programa de integridade da empresa?

Idem item 11. Realizamos a priorização destes processos com base em informações da própria ANEEL (volume de autuações, multas e penalidades por natureza, de todas as distribuidoras do País, disponível no site de ANEEL). 


\section{ANEXO 4 \\ QUESTIONÁRIO SOBRE O PROGRAMA DE INTEGRIDADE RESPONDIDO PELA SEGUNDA DISTRIBUIDORA AVALIADA}

1) Existe algum programa de compliance ou de integridade implementado na empresa? Desde quando?

Sim. Desde 2006. Atende a lei e vai além pois o programa é global. Vem dos EUA e prescreve a conformidade com o FCPA.

2) A empresa possui algum Código de Ética? Se possível anexar a esta pesquisa.

Sim, público, disponível no site da empresa.

3) Como foi o processo de decisão para implementar o programa de integridade? Qual a motivação da empresa? Se possível, anexar exposição de motivos.

A Motivação é top down de fora. Do acionista majoritário. Veio para cumprir um programa global da empresa.

4) Como funciona a estrutura de compliance da empresa (recursos, departamentos, reporte, número de funcionários, abrangência)? Se possível, anexar esquema de estrutura, fluxograma ou política interna.

Até junho/2018 - 11 profissionais reportando para o VP. Diretor de societário e compliance. Compliance dentro da auditoria. Gerência de compliance que responde ao diretor de auditoria.

5) Quais as políticas e procedimentos internos para divulgação do programa de integridade na empresa? Quais são? Se possível, anexar política interna. 
Existe um cronograma de treinamentos e de comunicação anual. Eventos de Ética. Compliance na integração de funcionário. O site da empresa era global e hoje é local. Não tem política escrita.

6) Como a empresa lida com eventuais conflitos decorrentes do programa de integridade de outras empresas terceiras com que ela se relaciona, ou seja, quando deve ser declarado estar em conformidade com o programa de compliance de outra empresa em detrimento do seu próprio?

Impõe o seu Programa de Integridade e código de ética.

7) Existe alguma política de compliance para fornecedores? Existe análise reputacional de fornecedores? De que tipo? Se possível, anexar esquema de estrutura, fluxograma ou política interna.

A empresa possui diretrizes internas de contratação, além de cláusulas de auditoria e de compliance nos contratos.

8) Quais são os mecanismos de controles internos da empresa para atendimento ao programa de integridade? Preventivo e detectivo. Se possível, anexar esquema de estrutura, fluxograma ou política interna.

Basicamente o SAP. Os controles são puramente administrativos. Existe a realização de monitoramento contínuo via auditoria.

9) Como é feito o monitoramento interno e externo do programa de integridade da empresa? Se possível, anexar esquema de estrutura, fluxograma ou política interna.

Através da realização de auditorias. Interna e externa.

10) Na sua opinião, existe algum tipo de ponto que não foi e deveria ser abordado pelo programa de integridade da empresa? 
Avaliação de riscos. Não tinha e está sendo montado. Não existia matriz de riscos formal. Agora existe uma política de formalização de documentos para comprovação da aplicação do compliance.

11) Existe alguma política de compliance regulatório na empresa? Quais são? Se possível, anexar política interna.

Não possui monitoramento pelo departamento de compliance.

12) Existe algum normativo de compliance da ANEEL? Se sim, a empresa o segue?

Específico para compliance não. $O$ que existe é um normativo da ANEEL estabelecendo níveis e práticas de governança, seguidas pela empresa.

13) Em sua opinião, quais os principais riscos regulatórios a que a empresa está sujeita, que poderiam dar ensejo a uma situação de "não compliance" ou "nãoconformidade"?

Existem riscos em relação aos indicadores regulatórios, no sentido de manipulação desses indicadores. Esse seria o principal risco. Outro risco seria em relação aos projetos de P\&D. Há também a questão das obrigações das distribuidoras, que devem ser integralmente cumpridas.

14) Existem monitoramentos de compliance específicos para o setor elétrico, que tenham sido implementados pela empresa?

Não sabe.

15) Existe algum tipo de monitoramento específico do setor elétrico que vc reputa importante ou que deveria ser considerado para inclusão no programa de integridade da empresa?

Não sabe. 